\title{
TESIS
}

\section{EVALUASI PERUBAHAN BAURAN PEMASARAN PENERBITAN PERS UNTUK MENINGKATKAN EFEKTIFITAS ORGANISASI}

(Studi Kasus Pada Penerbitan Pers Surat Kabar Harian Pagi Jawa Pos Surabaya)

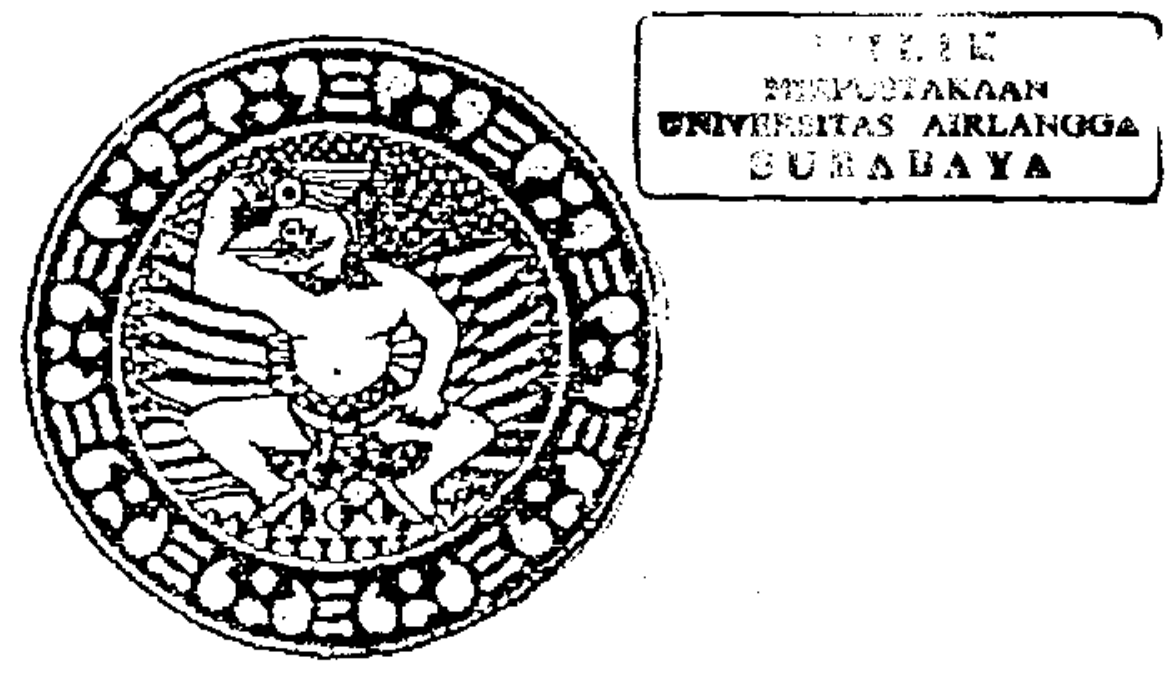

Disusun Oleh:

Muhammad Mufti Mubarok

NIM: 099910111L

PROGRAM STUDI ILMU MANAJEMEN

PROGRAM PASCA SARJANA

UNIVERSITAS AIRLANGGA

SURABAYA

2003 
Halaman Pengesahan

\title{
TESIS INI TELAH DISETUJUI \\ Tanggal \\ 2003
}

\section{Oleh}

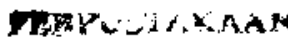
HNGEGTAS AIRLANOCA GUA BAXA

\section{Pembimbing Ketua}

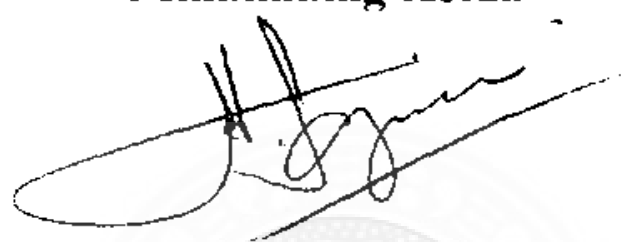

Drs. Tiiptohadi Sawariuwono,M.Ec.,Ph.D.,Ak

NIP:131123695

\author{
Mengetahui \\ Ketua Program Studi IImu Manajemen \\ Program Pasca Sarjana \\ Iniversitas Airlangga
}

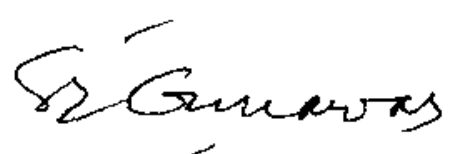

Drs.Sri Gunawan.M.Com.,DBA

NIP:131653420 
HALAMAN TELAH DIU.J

\section{PENETAPAN PANITIA PENGIJI}

Telah diuji pada:

Tanggal 2 Mei 2003

\section{Panitia Penguji Tesis:}

Ketua : $\quad$ Drs.Tjiptohadi Sawarjuwono,M.Ec.,Ph.D.,Ak

Anggota : $\quad$ 1. Prof .V. Hengky Supit,SE, $\Lambda \mathrm{k}$

2. Dra.Indriawati Usman,M.Sc

3. Dra.Nuri Herachwati,M.Si

4. Dra.Praptini Yulianti,M.Si

5. Dra Wiwik Supratiwi,MBA,Ak 


\section{Ucapinn Terima Kasih}

Alhamdulillah, segala puji dan syukur hanya milik Allah SWT, yang memiliki apa yang ada di langit dan di bumi. Dialah yang memiliki segala ilmu dan Maha Penolong, sehingga penulis dapat menyelesaikan tesis ini dengan baik dan lancar.

Sholawat dan salam semoga tercurahkan kepada Rasulullah Muhammad SAW, Nabi terbaik akhir zaman

Tesis ini berjudul " Evaluasi Perubahan Bauran Pemasaran Penerbitan Pers Untuk Meningkatkan Efektifitas Organisasi", semoga tugas akhir ini dapat memberikan manfaat kepada pembaca, khususnya kepada mereka yang tertarik pada kiat- kiat keberhasilan manajemen media massa terutama manajemen harian pagi Jawa Pos.

Pada kesempatan ini, dengan kerendahan bati penulis ingin menyampaikan terima kasih yang sebesar-besarnya, atas dukungan, sehingga terselesainya tesis ini. Terima kasih penulis sampaikan terutama kepada:

1. Keluarga di Lamongan, terutama Ibunda Siti Badriyah, Aba Nur Halim (alm), Ibu Mertua, Siti Zulaekha, ^ba Masyhuri (alm) sebagai orangtua dan mertua yang telah mencurahkan perhatitan dan do'anya.

2. Keluarga penulis, Istri dr.Indah Sri Yuliatin, anak-anak yang lucu, Muhammad Reforma Mufin Mubarok (mas Evo), Princesa Renata Anindya Mubarok (adik Echa) dan Dzirly Rosa Salsabillah Mubarok (alm), serta adik-adik, Muhibbul Haq, S.Kom, Khanifatussa'diyah, Abraham As'ad, S.Kom, Fitri Zuliana M, dan mbak Cicik atas segala kebaikannya yang telah diberikan pada penulis.

3. Bapak Drs.Tjiptohadi Sawarjuwono,M.Ec,Ph.D,Ak, Pembimbing utama penulis, terima kasih atas segala waktu, bimbingan, wejangan dan nasehatnya yang sangat berguna. 
4. Bapak Dr.Sri Gunawan.M.Com Ketua Jurusan Ilmu Manajemen Program Pasca sarjana Universitas Airlangga, atas segala dukungan dan perhatiannya pada penulis.

5. Bapak Ir. H Misbahul Huda Dirut, PJ Temprina, Jawa Pos Grup, atas segala dorongan moral kepada penulis.

6. Bapak-bapak di Jawa Pos, terutama Bapak Dahlan Iskan, CFO Jawa Pos, Bapak Nadim Zuhdi, Bapak Yamin Ahmad, Bapak Aziz, yang bersedia membantu penulis dalam interview dan diskusi yang menarik.

7. Teman-teman penulis, Mas Agus Miftah Surur, Mas Indra Nur fauzi, Mas Mummi, yang telah memberikan dukungan moral dan saran pada penulis.

8. Teman-teman Angkatan 99 Program Studi Ilmu Manajemen Program Pasca Sarjana Unair, tetutam Ibu Rinto, lbu Musrihah, Bapak Ferri, Bapak Siggit dan teman-teman yang sudah menyesaikan tesis.

9. Teman-teman Administrasi Pasca Sarjana Unair, atas bantuannya.

Tidak ada kesempurnaan sebuah karya manusia. Penulis menyadari masih banyak kekurangannya dalam menyusun tesis ini, untuk itu, jika ada kritik dan saran pembaca, Insya Allah dengan dengan lapang dada penulis terima dan sebagai acuan penulis untuk melanjutkan studi lebih tinggi lagi.

Akhir kata, penulis berdo'a, semoga Allah SWT selalu membuka pintu hati dengan cahayaNya dan mengajarkan ilmuNya kepada kita dan semoga tesis ini bermanfaat.

Surabaya, 2 Mei 2003

\section{Drs.M.Mufti Mubarok}




\section{Abstract}

The purpose of this research is to analyze whether the marketing mix increase the organization efectiveness in PT Jawa Pos. To make it depth and more focus, this research stress on four variable in marketing mix. Those are product, price, distribution, and promotion.

this research used Yin theory to analyze the phenomenon which is our main study. A lot of data is used to make it more valid. Data can be collccted from interview, file, document or direct observation.

This research uses research propotitions and compare them with chronological event which is our research fokus. So we can evaluate from the changing in marketing mix which have been done.

Briefly, the result is as follows:

1. the organization environment which make PT Jawa Pos performance worse, makes PT Jawa Pos must change all element in the marketing mix. The purpose of this is to minimize the business uncertainty.

2. the changing marketing mix proses in PT Jawa Pos have involved the decision makers. This factor is very important to give more succes probability according to the initial planning.

3. those strategy is done by having more formal and informal meeting. PT Jawa Pos choose participative and persuasive method. This approach is choosen so that labors can be accomodated and minimize conflict between labor and company.

4. Th changing process involved all elements of marketing mix. Those are product, price, distribution and promotion. This have been done with cooperation between other department in the company. With this cooperation the effectivity can be achieved. 


\begin{abstract}
Abstraksi
Penelitian ini untuk menganalisis apakah perubahan bauran pemasaran mampu meningkatkan efektifitas organisasi di PT Jawa Pos. Agar lebih terfokus dan mendalam, maka penelitian ini ditekankan semua unsur bauran pemasaran yaitu produk, harga, distribusi dan promosi.

Dalam penelitian ini, digunakan metode studi kasus eksploratoris yang mendasarkan pada teori Yin. Pendekatan ini digunakan untuk menganalisis fenomena yang dijadikan fokus penelitian. Agar hasil penelitian lebih valid, diperlukan banyak sumber bukti. Melalui pendekatan ini, penelitian dapat secara langsung melacak ke berbagai sumber bukti seperti wawancara, arsip, dokumen maupun dilakukan observasi secara langsung.

Dalam penelitian ini digunakan proposisi penelitian untuk dikomparasikan dengan krorıologi peristiwa yang sedang menjadi fokus penelitian. Dengan cara mengkomparasikan antara proposisi dengan peristiwa kronologis yang terjadi di dalam perusahaan, maka dapat diperolah suatu hasii evaluasi, dari proses perubahan bauran pemasaran yang telah dilakukan.

Secara ringkas, hasil penelitian tersebut dapat dijelaskan sebagai berikut:

1. Tekanan lingkungan organisasi yang mengakibatkan penurunan prestasi organisasi secara terus menerus mengharuskan PT Jawa Pos melakukan perubahan bauran pemasaran yang meliputi semua unsur dalam bauran pemasaran yaitu produk, harga, saluran distribusi dan promosi. Dengan melakukan perubahan tersebut PT Jawa Pos sedang berusaha meminimalisasi ketidakpastian usaha.
\end{abstract}

2. Proses perubahan bauran pemasaran pada PT Jawa Pos telah melibatkan unsur-unsur dominan dalam perusahaan sebagai agen dan pelaksana perubahan. Pelibatan unsur dominan dalam perusahaan sangat penting untuk bisa memberikan kemungkinan keberhasilan proses perubahan yang diperlukan untuk mempertahankan kelangsungan hidup perusahaan. Pelibatan unsur-unsur dalam PT Jawa Pos dilakukan melalui sosialisi yang intensif sehingga perubahan bauran pemasaran dapat terlaksana secara terencana, terarah sesuai dengan target yang ditetapkan.

3. Implementasi perubahan bauran pemasaran dilakukan dengan cara memperbanyak menggunakan forum resmi baik berupa rapat resmi perusahaan maupun forum-forum lain yang dibentuk untuk sosialisasi dan menampung berbagai pendapat dari karyawan manajemen maupun operasional. Di sini PT Jawa Pos lebih menempuh cara partisipatif dan persuatif. Pendekatan yang ditempuh PT Jawa Pos ini menjadikan proses perubahan bauran pemasaran menjadi berjalan sejalan dengan kondisi dan kultur karyawan PT Jawa Pos. Hal tersebut menjadikan tingkat konflik dapat dibatasi.

4. Proses perubahan bauran pemasaran PT Jawa Pos telah dilakukan secara tepat dengan melibatkan semua elemen-elemen bauran pemasaran, yaitu produk, harga, saluran distribusi dan promosi. Perubahan itu dilakukan dengan kerjasama yang sinergis antar departemen/divisi dalam perusahaan penerbitan pers. Dengan kerja sama yang sinergis antar departemen/divisi, efektifitas PT Jawa Pos bisa dicapai. 


\section{DAFTAR ISI}

ISI

HALAMAN

Ucapan Terima Kasih

Ringkasan.

Abstraksi.

Daftar Isi. iv

Daftar Gambar.

BAB I PENDAHULUAN.................................................. 1

A. Latar Belakang Masalah....................................... 1

B.Batasan Penelitian............................................ 8

C.Rumusan Masalah........................................... 9

D.Tujuan Penelitian ................................................ 10

E.Manfaat Penelitian............................................. 11

F.Sistematika Pembahasan ..................................... 11

BAB II TINJAUAN PUSTAKA........................................... 14

A.Teori Pengelolaan Perubahan............................... 14

B.Teori Bauran Pemasaran...................................... 19

C.Teori Efektifitas Organisasi.................................... 24

BAB II! KERANGKA KONSEPTUAL DAN PROPOSISI TESIS........... 28

A.Model Pengelolaan Perubahan............................... 28

B.Proposisi Penelitian.......................................... 32

BAB IV METODE PENELITIAN ........................................ 34

1.Metode Studi.................................................... 35

2.Jenis Data ...................................................... 35

3.Prosedur Pengumpulan Data............................... 37

4. Teknik Analisa................................................ 38

BAB V EVALUASI PERUBAHAN BAURAN PEMASARAN UNTUK MENINGKATKAN EFEKTIFITAS ORGANISASI.................. 41

1.Perbandingan proposisi pertama dengan faktor pendorong perubahan perusahaan.

2.Perbandingan proposisi ke dua dengan pembentukkan agen perubahan. .......................................... 43

3.Perbandingan proposisi ketiga dengan konflik dlm perusahaan...45

4.Perbandingan proposisi keempat dengan perubahan bauran pemasaran PT Jawa Pos. 
BAB VI PEMBAHASAN .................................................. 66

1.Keunggulan .................................................... 66

2.Kelemahan yang dapat diidentifikasi............................, 69

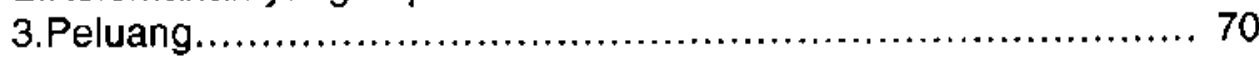

4.Ancaman....................................................... 71

5. Kelemahan dan kelebihan....................................... 73

BAB VII KESIMPULAN DAN REKOMENDASI.......................... 76

A.Kesimpulan..............................................., 76

B.Rekomendasi............................................... 77

Dattar Pustaka....................................................... 79

Daftar Lampiran

1.Kerangka penelitian Evaluasi peristiwa $X$ dengan pendekatan studi kasus Yin .................................................. 80

2. Rangkuman Komparatif peristiwa dalam perusahaan dengan proposisi penelitian.................................................. 81

3. Draf Pertanyaan yang diajukan.................................... 84

4.Laporan Penelitian dokumen/arsip dan wawancara.................. 87

5.Laporan Oplah Jawa Pos.............................................. 114

6. Laporan Keuangan ................................................ 115 


\section{BAB I}

\section{PENDAHULUAN}




\section{BAB I}

\section{PENDAHULUAN}

\section{A. LATAR BELAKANG MASALAH}

Krisis ekonomi yang menimpa negeri ini sejak akhir tahun 1997 berbeda sekali dengan krisis yang terjadi sebelumnya. Krisis kali ini lebih berat, lebih kompleks, biayanya (cost of crisis) lebih tinggi, dan dampak negatifnya sangat luas, termasuk telah memukul industri pers nasional akibat melonjaknya harga bahan baku seperti kertas, tinta dan biaya pemeliharaan peralatan produksi.

Pada saat yang sama, masyarakat hidup dalam dunia yang makin kompleks dan modern. Banyak kebutuhan yang harus dipenuhi dalam rangka memenuhi kebutuhan hidupnya, bahkan terus berkembang seirama dengan perkembangan yang ada di sekitarnya. Salah satu kebutuhan masyarakat yang semakin modern adaiah kebutuhan informasi. Banyak sarana yang menawarkan suatu produk berupa informasi, yaitu melalui berbagai media. Berbagai media yang ada antara lain, media cetak dapat berupa surat kabar harian, majalah, jurnal dan sebagianya, dan media elektronik antara lain radio, telephone, faximile dan internet.

Media yang menawarkan berbagai informasi ini mempunyai ciri khas yang berbeda-beda, masing-masing memiliki kebaikan dan juga memiliki kelemahan-kelemahan yang melekat pada produk yang dihasilkannya. Dalam rangka tersedianya informasi, seseorang tidak akan lepas dari usaha-usaha untuk melakukan keputusan pembelian, sebab secara umum sarana itu tidak dapat diperoleh secara gratis. 
Salah satu produk yang dianggap paling penting untuk mendapat perhatian adalah surat kabar, sebab surat kabar ini memiliki keunikan tersendiri yang tidak terdapat di media lain, misalnya: kecepatan informasi, dapat disimpan, dapat dibaca sesuai dengan waktu yang diinginkan, dapat dibawa kemana saja dan sebagainya.

Terkait dengar, situasi yang serba sulit akibat krisis ekonomi, maka kesuksesan bisnis dalam industri pers sangat ditentukan sejauh mana perusahaan mampu melakukan perubahan sesuai dengan perubahan yang ada pada lingkungan perusahaan. Keputusan melakukan perubahan harus tetap memperhatikan lingkungan yang ada di sekitarnya, karena perusahaan hidup dan tumbuh di dalam suatu lingkungan yang mengelilinginya. Selain itu, perusahaan juga harus memperhatikan problem riil internal perusahaan, dan mencoba mengatasi persoalan tersebut dengan langkal! perubahan manajemen yang diperlukan.

Berbagai problem dalam perusahaan terkait langsung dengan fenomena krisis 1997. Pada Juli 1997, nilai tukar rupiah terhadap dolar AS masih berkisar Rp. $2.700,00$ per dolar. Namun, sejak itu nilai tukar terus mengalami fluktuasi yang begitu cepat dan cenderung meılurun hingga pernah anjlok sampai Rp. $17.000,00$ per dolar.

Selain banyak perusahaan yang utangnya membengkak, krisis moneter juga mengakibatkan banyak perusahaan bangkrut. Kondisi sulit seperti itu juga dialami perusahaan penerbitan pers. Perusahaan surat kabar menghadapi persoalan yang serba dilematis. Sebab, harga bahan baku koran terus naik sementara pemasukan dari iklan menurun. Melihat 
perkembangan ini perusahaan surat kabar seharusnya menaikkan harga jual produknya jika tidak mau rugi. Namun, jika melihat daya beli sebagian masyarakat yang sedang menurun, kenaikan harga jual itu belum tentu menguntungkan perusahaan. Bahkan, malah bisa menjadi bumerang, karena mengakibatkan sebagian masyarakat tidak mau atau merasa tidak mampu membeli koran yang harganya dinaikkan.

Faktor dominan yang membuat perusahaan pers kesulitan selama 2001 adalah tidak stabilnya harga kertas koran sebagai bahan baku utama surat kabar selama 2001. Harga kertas koran berfluktuasi secara cepat sehingga perusahaan pers kesulitan memprediksikannya. Fluktuasi harga kertas koran bisa dilihat pada tabel di bawah ini :

Tabel 1.1.

Fluktuasi Harga Kertas Koran

\begin{tabular}{|l|l|}
\hline Periode & Harga/ kilogram \\
\hline 26 Juli 2000 & Rp. $2.416,00$ \\
31 Oktober 2000 & Rp. $3.006,00$ \\
28 Februari 2001 & Rp. $6.166,00$ \\
30 Maret 2001 & Rp. $5.746,00$ \\
29 April 2001 & Rp. $5.266,00$ \\
Mei 2001 & Rp. $7.966,00$ \\
27 Juni 2001 & Rp. $9.146,00$ \\
Juli 2001 & Rp. 7.780,00 \\
\hline
\end{tabular}

(Sumber: Serikat Penerbit surat kabar jatim )

PT. Jawa Pos, perusahaan swasta yang menerbitkan surat kabar harian Jawa Pos, juga mengalami banyak kesulitan. Sebab, selain pemasukan dari iklan menurun seiring dengan perekonomian yang sedang lesu, beban utang perusahaan juga meningkat akibat selisih kurs. Namun, berkat berbagai terobosan yang dilakukan manajemennya, 
perusahaan ini bisa berkelit dari deraan krisis ekonomi. Bahkan bisa meningkatkan jumlah pembacanya.

Jawa Pos edisi 6 Desember 1998 melaporkan, selain mampu menaikkan jumlah pembaca dan tetap menguasai pangsa pasar koran di Jatim, PT. Jawa Pos tahun 1998 juga meraih penghargaan Top Marketing 1998 dari The Business Inside Mark Plus Jakarta. Ada 17 perusahaan nasional dan multinasional yang mendapatkan anugerah ini. Perusahaan-perusahaan peraih penghargaan itu dinilai sukses dan kreatif dalam menjalankan strategi bauran pemasaran di masa krisis.

Hanya Perusahaan Pers profesional yang mampu melakukan perubahan bauran pernasaran dan inovatif agar bisa bertahan hidup kemudian keluar dari krisis. Bagi perusahaan pers yang sudah terbit, tantangan untuk hidup (survival) adalah tantangan yang harus dihadapi dengan semangat juang tinggi (fighting spirit) serta dilengkapi dengan jiwa kewirausahaan (entrepreneurship) yang tangguh dan selalu responsif untuk melakukan perubahan sesuai dengan perubahan lingkungannya.

Perusahaan pers harus belajar banyak dari kesulitan, kemunduran usaha, dan kegagalan usaha yang terjadi selama krisis berlangsung. Perusahaan pers juga harus bisa belajar dari kisah sukses penerbitan pers di masa krisis. Ada beberapa modal yang harus dimiliki oleh perusahaan pers agar bisa mencapai sukses di masa krisis:

1. Memahami perilaku dan keingingan pembaca.

2. Kecenderungan perubahan sosial.

3. Kiat-kiat kompetitor . 
4. Mengamati dan menangkap perubahan teknologi, ekonomi, politik dan sosial.

Jika ada pembaca yang menghentikan langganan atau pindah ke penerbit lain, perlu disikapi sebagai bagian dari jerilaku konsumen. Dalam konteks seperti inilah peran manajemen harus lebih dioptimalkan, atau jika diperlukan dilakukan perubahan guna optimalisasi peran manajemen. Optimalisasi peran manajemen akan sangat menentukan sejauhmana surat kabar berhasil merebut hati pembaca. Perubahan demi tercapainya optimalisasi peran manajemen semakin penting karena pers tidak hanya bersaing dengan media cetak saja tetapi juga dengan radio dan televisi, yang sama-sama menjual berita dan iklan.

Bisnis penerbitan pers memang harus dilengkapi dengan penerapan manajemen secara profesional. Maka sebelum terjun ke bisnis penerbitan pers, pengelola media massa harus dapat menyesuaikan diri dengan mencoba menguasai situasi untuk kepentingan pangsa pasar. Karena sebenarnya dalam persaingan bisnis media massa, kekuatan pasar pada akhirnya akan tetap jadi pemenang.

Perusahaan pers yang menerapkan prinsip-prinsip manajemen pers dan selalu responsif untuk melakukan perubahan sesuai perubahan lingkungan perusahaan yang akan jadi pemenang ditengah persaingan yang ketat. Karena bisnis penerbitan pers pada prinsipnya adalah perpaduan dari tiga kegiatan bisnis yaitu bidang redaksional, bidang percetakan, dan bidang unit usaha. Ketiga usaha ini dalam kegiatannya harus saling berkait dan mendukung satu sama lain. Penerapan manajemen pers mendapat tantangan serius di saat krisis moneter, 
terutama akibat harga bahan baku penerbitan pers naik dan cenderung berfluktuasi. Perusahaan pers diuji pada ketiga komponen utama pers tersebut bersinergi dan mengatur strategi menghadapi situasi yang serba sulit.

Melonjaknya harga bahan baku media cetak (kertas, tinta, plate, film, dan lain-lain) menyebabkan harga jual koran menjadi tinggi, daya beli masyarakat menurun, akibatnya koran media cetak yang oplahnya kecil bisa langsung tutup. Situasi sulit di atas, harus direspon penerbitan pers dengan mengambil langkah-langkah perubahan strategis seperti: mengalihkan perhatian secara eksternal, mendulang pendapatan dari menjual iklan, dan melakukan perubahan strategi pemasaran.

Secara Internal, melakukan efisiensi di setiap unit usaha. Dan berusana memperoleh suntikan dana segar. Efisiensi bagi manajemen media massa juga mutlak adanya. Maka, perusahaan pers taarus mengajak staf-stafnya di semua bagian mengutamakan hal-hal yang dapat diprioritaskan demi kelangsungan hidup (survival) melalui perilaku kerja seperti:

1.Mengurangi pembelian fasilitas dan sarana kerja, terutama perangkat keras seperti komputer, printer, spare part, percetakan, dlı, kecuali jika benar-benar diperlukan.

2. Melakukan penghematan pemakaian kertas, listrik, telpon, alat tulis kantor, dll.

3. Staf administrasi dapat dididik menjadi sales iklan, dll.

Berbagai langkah yang ditempuh perubahaan tersebut terbukti efektif bagi kelangsungan hidup PT Jawa Pos. Karena itu, apa yang 
dicapai PT. Jawa Pos Surabaya selama krisis ekonomi menarik untuk dikaji. Prestasi itu termasuk luar biasa. Sebab, di tengah krisis moneter dan ekonomi yang cukup berat, justru manajemen perusahaan ini bisa meningkatkan jumlah pembacanya, dan bisa meraih penghargaan Top marketing 1998. Keberhasilan itu merupakan salah satu fenomena menarik untuk diteliti dan dikaji lebih mendalam. Prestasi yang diraih PT. Jawa Pos itu tidak hanya menarik dijadikan bahan kajian secara lebih mendalam oleh kalangan akademis, namun juga oleh para manajer perencanaan, terutama praktisi pemasaran.

Banyak hal yang layak dan perlu diketahui dari PT.Jawa Pos antara lain, bagaimana perusahaan ini melakukan perubahan bauran pemasaran untuk menyiasati badai krisis ekonomi. Kiat-kiat pemasaran perusahaan yang kini berkantor di Graha Pena Jalan A. Yani No. 88 Surabaya ini menarik untuk diketahui. Mengapa di saat banyak Perusahaan bangkrut, di saat daya beli masyarakat kian menurun, justru PT. Jawa Pos bisa meningkatkan jumlah pembacanya. Itulah sebabnya penulis memilih untuk melakukan penelitian, dengan judul: EVALUASI PERUBAHAN BAURAN PEMASARAN PENERBITAN PERS UNTUK MENINGKATKAN EFEKTIFITAS ORGANISASI. (Studi Kasus Pada Penerbitan Pers Surat Kabar Harian Pagi Jawa Pos Surabaya).

Sesuai dengan judul di atas, maka penelitian berusaha memvisualisasi peristiwa-peristiwa manajerial, yaitu mengungkapkan bagaimana suatu perubahan bauran pemasaran secara menyeluruh dilakukan. 
Untuk melakukan evaluasi peristiwa perubahan, digunakan teoriteori sebagai kriteria perubahan sebagai berikut :

1. Teori tentang pengelolaan perubahan manajemen

2. Teori tentang bauran pemasaran (marketing mix)

3. Teori tentang efektifitas organisasi

\section{B. BATASAN PENELITIAN}

Mengingat perubahan bauran pemasaran menyangkut beberapa aspek, maka dalam penelitian ini dilakukan pembatasan penelitian sebagai berikut :

1. Penelitian ini merupakan evaluasi terhadap perubahan bauran pemasaran (marketing mix) dalam rangka meningkatkan efektifitas organisasi.

2. Perubahan adalah menyangkut desain dan pelaksanaan perubahan. Desain yang dimaksud adalah desain teoritik peneliti dan pelaksanaan perubahan adalah realitas empirik yang terjadi sejak keputusan dilakukan perubahan bauran pemasaran, penentuan lingkup perubahan, penyusunan tim yang bertanggung jawab terhadap perubahan, program dan proses/cara perubahan serta hasii-hasilnya.

3. Perubahan bauran pemasaran diarahkan pada empat faktor dalam bauran pemasaran yang disebutkan dengan $4-P$ (The Four Ps) yang terdiri atas product (produk), price (harga), place (tempat atau saluran distribusi), dan promotion (promosi). 
4. Tujuan dari perubahan adalah untuk rieningkatkan efektifitas organisasi. Efektifitas organisasi menyangkut aspek kuantitatif dan kualitatif. Masalah efektifitas organisasi ini akan diperdalam di bab landasan teori.

\section{RUMUSAN MASALAH}

Berdasarkan latar belakang yang telah diuraikan sebelumnya, maka ada beberapa permasalahan yang perlu dikaji dan diteliti sehingga diperoleh suatu pemahaman yang menyeluruh mengenai bagaimana manajemen penerbitan pers Jawa Pos mengambil keputusan strategis meningkatkan efektifitas perusahaannya melalui perubahan bauran pemasaran.

Berdasarkan fenomena tersebut di atas maka bisa dirumuskan permasalahan sebagai berikut:

1. Apakah tekanan lingkungan organisasi mengakibatkan penurunan prestasi organisasi secara terus menerus sehingga organisasi akan melakukan perubahan bauran pemasaran?

2. Apakah dalam perubahan bauran pemasaran diperlukan formalisasi proses perubahan dengan mengikutsertakan kekuatan dominan organisasi sebagai agen (penanggung jawab) dan pelaksana perubahan?

3. Apakah proses perubahan disosialisasikan dan diimplementasikan sesuai dengan kultur dan tujuan karyawan sehingga tidak memunculkan konflik? 
4. Apakah perubahan bauran pemasaran yang memerlukan kerja sama sinergis antar departemen/devisj mampu meningkatkan efektifitas organisasi?

\section{TUJUAN PENELITIAN}

Berdasarkan permasalahan diatas, maka penelitian ini mempunyai tujuan sbb:

1. Menilai proses perubahan bauran pemasaran penerbitaı pers dalam kaitannya dengan efektifitas perusahaan yang telah djjalankan penerbitan pers.

2. Mengetahui dan mendiskripsikan bagaimana perbedaan antara realita perubahan antara teori dan acuan dalam penelitian.

3. Menilai pertimbangan-pertimbangan dalam melakukan perubahan yang saling berkait, meliputi:

a. Penilaian tekanan eksternal perusahan penerbitan pers yang tidak mampu direspon oleh perusahaan, sehingga diperlukan perubahan-perubahan bauran pemasaran.

b. Menilai proses perubahan yang mengikut sertakan kekuatan internal perusahaan.

c. Menilai setiap perubahan untuk mengendalikan konflik baik secara internal maupun eksternal.

d. Menilai sejauhmana pelaksanaan perubahan bauran pemasaran penerbitan pers dalam mengendalikan dan memperbaiki efektifitas perusahaan. 


\section{E. MANFAAT PENELITIAN}

Dari hasil penelitian ini, diharapkan dapat memberikan manfaat sebagai berikut:

a. Memberi gambaran, khususnya bagi peneliti terutama yang berminat pada manajemen penerbitan pers, mengenai perubahan bauran pemasaran penerbitan pers sebagai keputusan strategis untuk membangun media massa yang berorientasi bisnis.

b. Diharapkan menambah khasanah penelitian ilmiah di bidang ilmu manajemen khususnya metode penelitian pada manajemen penerbitan pers.

c. Memberikan sumbangan pikiran dan informasi yang obyektif kepada manajemen Jawa Pos tentang langkah-langkah perubahan bauran pemasaran penerbitan pers yang telah dan akan ditempuh.

\section{F. SISTEMATIKA PEMBAHASAN}

Sistematika pembahasan tesis sebagai berikut :

1. BAB I. Pendahuluan, berisi tentang:

a. Latar belakang yang menguraikan pentingnya serubahan manajemen penerbitan pers dan pendekatan dalam meneliti pelaksanaan perubahan bauran pemasaran penerbitan pers.

b. Perumusan batasan masalah.

c. Perumusan masalah penelitian. 
d. Perumusan tujuan penelitian.

e. Perumusan manfaat penelitian.

f. Sistematika pembahasan yang berisi tentang uraian singkat sistematika penulisan dan pembahasan penelitian.

2. BAB II. Tinjauan Pustaka, menguraikan tantang :

a. Landasan teori Jesain perubahan, yaitu uraian teori perubahan manajemen

c. Landasan Teori Bauran Pemasaran (Marketing Mix), yaitu teori tentang elemen-elemen penting dalam manajemen pemasaran.

c. Landasan Teori Efektifitas Organisasi

3. BAB III. Kerangka konseptual penelitian dan proporsi penelitian

a. Model pengelolaan perubahan manajemen

b. Proposisi penelitian

3. BAB IV. Metode Penelitian, menguraikan langkah-langkah penelitian studi kasus PT Jawa Pos.

1. Metode Studi

2. Jenis Data
a. Data Primer
b. Data Sekunder

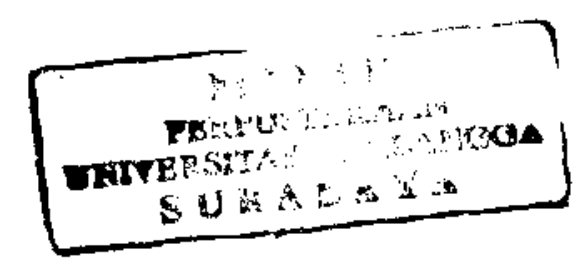

3. Prosedur Pengumpulan Data
a. Penelitian Pendahuluan
b. Penelitian Lapangan

4. Teknis Analisa 
4. $B A B$ V: Evaluasi Perubahan manajemen penerbitan pers untuk meningkatkan efektifitas perusahaan pada Surat Kabar Harian Pagi Jawa Pos yang berisi tentang :

Evaluasi terhadap kronologi empirik perubahan manajemen untuk meningkatan keefektifan organisasi

5. BAB VI. Pembahasan, yang memuat analisis dampak perubahan keunggulan setelah perubahan dan kemungkinan kelemahannya

6. BAB VII: Kesimpulan dan Rekomendasi, berisi tentang

a. Kesimpulan dari penelitian evaluasi

b. Saran langkah-langkah perubahan yang sedang dan akan ditempuh khususnya obyek penelitian. 


\section{BAB II}

\section{TINJAUAN PUSTAKA}




\section{BAB II}

\section{TINJAUAN PUSTAKA}

Dalam bab ini akan dibahas mengenai landasan teori yang digunakan dalam penelitian ini yaitu, teori manajemen perubahan, teori bauran pemasaran (marketing mix) dan teori efektifitas organisasi.

\section{A. TEORI PENGELOLAAN PERUBAHAN}

Organisasi memerlukan perubahan yang luas, apabila organisasi tersebut memperoleh tekanan yang kuat dari lingkungan yang tidak mampu diantisipasi oleh kondisi internal organisasi pada saat itu. Di sinilah peran manajemen perubahan akan sangat menentukan sejauhmana kemampuan perusahaan dalam merespon perubahan yang sangat luas itu. Dalam hal ini Robbin (1994: 395, 427) menguraikan masalah perubahan ini sebagai berikut:

Tindakan yang paling komprehensif yang diambil oleh manajemen jika menghadapi lingkungan yang tidak menguntungkan adalah dengan berpindah ke dominan yang mempunyai ketidakpastian lingkungan yang lebih sedikit.

Dan penurunan prestasi yang terus menerus......melakukan sejumlah perubahan yang dapat disebut "komprehensif" atau sistem yang luas".. menggunakan strategi yang lebih berorientasi pada pasar. Lini produksi dipotong... penekanan lebih diberikan kepada manajemen lini produksi, penjualan dan pemasaran.

Lebih jauh Robbin (1994: 421-437) menjelaskan perubahan sebagai berikut:

1. Kekuatan yang memprakarsai Perubahan 
Faktor-faktor yang dapat memprakarsai perubahan struktural pada dasarnya suiti untuk diperhitungkan jumlahnya, namun dapat dikelompokkan menjadi kategori yaitu eksternal dan internal.

Faktor eksternal antara lain perkembangan ekcnomi, peraturan pemerintah, tindakan para pesaing, pemasok, perkembangan teknologi dan lain-lain.

Faktor internal: perubahan misi, visi dan tujuan, penggabungan atau akuisisi, pembelian peralatan baru, peningkatan kualitas, peningkatan pelayanan dan pemuasan pelanggan, imlementasi dari sistem informasi baru yang lebih canggih, meningkatkan volume produksi dan diversifikasi, kelangkaan atau semakin meningkat jumiah tenaga kerja, menurunnya moral pegawai, menurunnya keuntungan, meningkatnyaa turn over, dll.

\section{Agen Perubahan}

Agen perubahan adalah mereka yang memprakarsai perubahan. Mereka tersebut terdiri dari orang perusahaan, antara lain pemilik, pihak manajemen baik eksekutif senior, menengah, spesialis pengembangan staf maupun pegawai tingkat rendah. Bisa juga dari Iuar atau konsultan. Namun biasanya konsultan terlihat sebagai alat manajemen.

\section{Apa yang harus berubah}

Faktor yang dapat dirubah meliputi: (1) struktur, termasuk klasifikasi struktur adalah rantai komando, kewenangan, alokasi imbalan, tingkat 
formalisasi. (2) Teknologi, yang terdiri antara lain modifikasi peralatan (3) proses organisasi, antara tain proses pengambilan keputusan, pola komunikasi.

4. Proses Perubahan

Proses perubahan organisasi dan manajemen melalui tiga tahap, yaitu (1) pencarian status quo (unfreezing), (2) perpindahan pergerakan (moving), (3) pembekuan kembali (refreezing) untuk menjadi permanen. Perubahan tiga tahap tersebut antara lain untuk memastikan bahwa kondisi sebelum perubahan akan hilang dan perubahan tersebut dapat dipertahankan.

Proses pencarian (unfreezing) dapat dicapai dengan cara:

a. Menjadikan kekuatan pendorong perubahan mengarahkan perilaku menjadi dari status quo.

b. Mengurangi kekuatan penghambat yang menghalangi perpindahan dari ekuilibrium yang ada.

c. Kombinasi dari kedua cara tersebut.

Jika pencarian telah terlaksana, maka gerakan (moving) ke arah perubahan dapat dijalankan. Pada saat demikian agen perubahan memperkenalkan satu atau lebih strateginya. Namun dalam kenyataan, tidak terdapat pernisahan yang jelas antara pencairan dan pergerakan atau perpindahan.

Langkah berikutnya adalah pembekuan (refreezing) kembali.

Faktor-faktor yang harus diperhatikan dalam pembekuan kembali adalah:

a. Formalisasi 
Yaitu memformalkan kekuatan yang mendorong melalui peraturan formal, baik yang mengatur perilaku maupun prosedur-prosedur kerja. Hal ini dilakukan dengan meninjau kembali peraturan-peraturan formal yang berlaku sebelumnya, untuk memperkuat situasi yang baru.

\section{b. Sistem Alokasi}

Hal ini penting untuk memenuhi harapan dalam jangka waktu tertentu, agar momentum perubahan dapat dipertahankan dan tidak pendek umurnya.

c. Legitimasi

Legitimasi perubahan biasanya diperoleh dari tingkat tertinggi dari hirarkhi manajemen, yang harus bias menjamin akan tercapainya harapan yang lebih baik akan terjadinya perubahan. Kegagalan menyampaikan informasi mengenai harapan akan mengurangi tingkat pembekuan kembali.

d. Kekuatan kelompok

Hal ini juga merupakan faktor penting, ketika pegawaj mulai mengetahui bahwa yang lainya dalam kelompok mereka menerima dan menyetujui perubahan tersebut, mereka akan lebih bisa mudah menerima hal tersebut.

e. Komitmen

Kornitmen terhadap perubahan mengakibatkan penerimaan terhadap perubahan lebih besar dari lebih pasti. Jika para pegawai turut serta daiam keputusan mengenai perubahan tersebut, maka mereka dapat diharapkan akan merasa lebih terikat untuk menjadikannya berhasil.

5. Pilihan taktik dalam melakukan perubahan sebagai berikut: 


\section{a. Intervensi (Campur Tangan)}

Dalam taktik ini, agen perubahan memberikan argumentasi bahwa prestasi yang ada kurang memadahi, lalu menetapkan standar-standar baru. Agen perubahan kemudian merujuk organisasi yang sebanding atau unit yang berprestasi lebih baik sebagai contoh untuk mengesahkan (melegitimasi) kebutuhan perubahan dan kemudian secara eksplisit menjelaskan cara memperbaiki keadaan. Dalam taktik ini, untuk memperlancar perubahan, agen perubahan membentuk gugus tugas yang terdiri dari pegawai yang sudah dipengaruhi dan agen perubahan bisa memveto rekomendasi dari giugus tugas tersebut.

b. Partisipasi (Penyertaan)

Agen perubahan mengemukakan tentang rincian kebutuhan akan perubahan serta peluang yang mungkin akan didapat dari perubahan. Setelah itu menunjuk atau menciptakan gugus tugas untuk melakukan tugas tersebut, serta mendelegasikan wewenang bagi proses perubahan tersebut karena gugus tugas, dibarengi dengan penyertaan tentang harapan maupun hambatannya. Jadi kekuasaan penuh diberikan kepada gugus tugas, dan agen perubahan tidak menggunakan kekuasaan veto atas keputusan yangi diambilnya.

c. Persuasi (Peyakinan)

Agen perubahan mengidentifikasi kebutuhan atau peluang perubahan, kemudian meminta bantuan kepada para pakar menyampaikan ide-ide mereka untuk melakukan perubahan. Setelah 
berbagai ide ditawarkan oleh berbagai pihak dianggap bisa dilaksanakan mak agen perubahan menjadi aktif mengimplementasikannya.

d. Edict ( Pemaklumatan)

Manajemen puncak membuat keputusan tentang perubahan struktural secara sepihak. Mereka menghindari partisipasi apa saja, dan memberitahukan kepada mereka yang terkena, mengenai bagaimanakah berubahan bentuk itu nantinya. Agen perubahan memberitahukan perubahan-perusahan tersebut dengan menggunakan memo, dan presentasi formal untuk menyampaikan keputusannya.

\section{Hasil-Hasil}

Puncak dari perubahan adaiah timbulnya efek tertentu pada efektifitas organiasi. Apakah dampak tersebut positif, negatif, sementara atau permanen.

\section{B. TEORI BAURAN PEMASARAN}

Kotler (1996 : 92 ) mendefinisikan bauran pemasaran (marketing mix) adalah seperangkat alat-alat pemasaran yang dipakai perusahaan untuk mengejar tujuan pemasarannya di dalam target pasar. Ada empat faktor dalam bauran pemasaran itu yang disebutkan dengan $4-P$ (The Four Ps) yang terdiri atas product (produk), Price (harga), place (tempat atau saluran distribusi), dan promotion (promosi).

Menurut Adrian Payne (2001: 231), dalam konteks strategis, perencanaan pemasaran memiliki dua langkah yaitu menentukan misi 
dan mengidentifikasi tujuan-tujuan korporat. Ini diawali langsung dari proses perencanaan strategik. Penting kiranya mengidentifikasi konteks strategik rencana pemasaran untuk mamastikan bahwa tujuan-tujuan dan strategi-strategi pemasaran spesifik lebih diarankan pada keseluruhan kebutuhan korporat perusahaan.

Pemasaran sebagai strategi, menyangkut berbagai unsur yang kemudian dikenal dengan bauran pemasaran (marketing mix). Unsur produk (product), antara lain menyangkut variasi, kualitas, desain, ciri-ciri khusus, nama merek, pengemasan, ukuran, layanan, dan jaminan. Unsur harga (price) meliputi pemberian diskon, cara dan waktu pembayaran. Unsur distribusi atau tempat (place) menyangkut chanel (jaringan), jangkauan pelayanan, tempat persediaan (stock), dan sarana angkutan. Sedangkan unsur promosi (promotion) menyangkut sales, Promotion, adversiting, sales force, public relations, and direct marketing.

Irawan (1996: 85 ) membagi produk dilihat dari pemakaiannya menjadi empat. Yaitu barang konsumen yaitu barang yang dipakai oleh konsumen akhir individual tanpa proses atau pengolahan komersial lebih lanjut. Kemudian barang konvenien yaitu barang konsumen yang biasanya dibeli berulang kali, mudah diproleh, dan dengan pengorbanan usaha yang paling minimum. Barang belanjaan yaitu barang -barang yang oleh pembeli dibandingkan atas dasar kesesuaian, kualitas, harga dan style sebelum calon pembeli memutuskan untuk membeli. Kemudian satu lagi barang khusus yaitu barang- barang yang berciri istimewa dalam kualitas, pelayaran yang diberikan atau keadaan yang khas, dan bukan karena harga. 
Jika ditilik dari kiteria yang diberikan Irawan itu, produk surat kabar bisa masuk pada barang konsumen karena ia dipakai oleh konsumen akhir individual tanpa proses atau pengelolaan komers. al lebih lanjut. Juga bisa dikategorikan sebagai produk konvenien karena dibeli berulang kali, mudah diperoleh, dan dengan pengorbanan usaha yang paling minimum. Namun produk surat kabar juga bisa dikategorikan sebagai produk belanjaan karena pembeli membanding- bandingkan tentang kualitas, harga dan style sebelum mereka membeli.

Unsur lain dalam bauran pemasaran (Marketing mix) adalah penetapan harga. Menurut Irawan (1996: 113), tujuan perusahaan menetapkan harga ada empat, yaitu mendapatkan laba maksimum, pengembalian investasi, mencegah atau mengurangi persaingan, dan mempertahankan atau memperbaiki pangsa pasar.

Ada tiga pertimbangan dalam menetapkan harga, yaitu atas dasar biaya, harga bersaing, dan berdasar harga persepsi. Untuk produk konvenien, pertimbangannya adalah harga produk. Sedangkan untuk produk belanjaan (shopping) pertimbangannya adalah harga bersaing. Kemudian untuk produk spesial pertimbangannya adalah harga persepsi.

Sedangkan menurut Kotler (1987: 4), keputusan-keputusan yang diambil oleh perusahaan mengenai harga dipengaruhi oleh sejumlah faktor faktor intern yang meliputi sasaran pemasaran, strategi marketing mix, dan organisasi perusahaan. Faktor ekstern yang mempengaruhi terdiri atas sifat pasar dan permintaan, persaingan, serta faktor-faktor lingkungan lainnya. 
Dalari hal distribusi, Irawan (1996: 138) membagi empat tingkat saluran. Pertama, saluran - nol - tingkat (saluran pemasaran langsu.ng), yaitu dari produsen langsung ke konsumen. Kedua, saluran - satu tingkat mempunyai satu perantara. Dalam pasar konsumen, perantara sekaligus sebagai pengecer, dan baru kemudian ke konsumen. Ketiga saluran dua tingkat mempunyai dua perantara Dalam pasar konsumen mereka merupakan grosir atau pedagang besar, dan pengecer. Dari sini barang kemudian sampai ke konsumen. Keempat, saluran tiga tingkat mempunyai tiga perantara. Dalam pasar konsumen mereka merupakan grosir, pemborong, dan pengecer. Dari sini barang lalu dikirim atau sampai ke konsumen.

Satu unsur yang terakhir dalam bauran pemasaran (Marketing mix) adalah promosi. Dalam pandangan Kotler (1995: $370-371$ ) promosi lebih menekankah pada keunggulan yang dimililiki perusahaan). Sedangkan tujuan dari promosi atau periklanan itu harus berdasarkan keputusan sebelumnya mengenai pasar sasaran, penentuan posisi pasar, dan bauran pemasaran (Kotler, 2002: 658-65).

Inti promosi adalah komunikasi. Sedikitnya ada lima hal yang perlu diperhatikan dalam melakukan promosi. Pertama, apa yang akan disampaikan. Ini menyangkut isi pesan promosi. Kedua, kepara siapa akan disampaikan. Ini menyangkut komunikan / khalayak. Ketiga, siapa yang akan menyampaikan. Ini menyangkut komunikatornya. Keempat, bagaimana cara menyampaikannya. Ini menyangkut media yang akan dipakai untuk berpromosi . 
Secara umum, bisnis surat kabar punya karakteristik yang berbeda dari bisnis kainnya. Dalam hal produk, misalnya, bagi surat kabar harian, perusahaannya harus mencetak dalam jumlah eksemplar tertentu setiap hari, dan harus habis pada hari itu juga (sehari ). Jika tidak laku, maka sudah tidak ada harapan inntuk bisa laku pada hari berkutnya. Ini berarti menuntut kecermatan strategi pemasaran, kualitas produk, dan kecepatan dalam menyampaikan produk ke pelanggan.

Dalam soal harga (price), harga surat kabar juga termasuk peka. Sebabnya, dilinat dari struktur pasarnya, pasar surat kabar termasuk pasar oligopoly. Menurut Irawan (1996: 111), pasar oligopoly industrinya terdiri atas beberapa penjual yang sangat peka terhadap strategi pemasaran dan penetapan harga perusahaan lain. Perusahaan dalam menetapkan harga harus memperhatikan perusahaan lain karena akan mengundang reaksi oleh perusahaan lain.

Dalam soal distribusi (place), bisnis surat kabar, terutama harian, juga dituntut memberikan perhatian yang lebih. Oleh karena itu menurut Gitosudarmo(2000: 257), perusahaan bisa menggunakan pihak Juar untuk membantu menyalurkan barang-barangnya kepada konsumen. Pihak luar tersebut merupakan pedagang penyalur atau pedagang perantara.

Surat kabar pada umumnya tidak punya jaringan yang luas, sehingga masyarakat tidak bisa dengan mudah membelinya atau mendapatkannya, maka peluang produknya untuk laku juga menjadi kecil. Jika seseorang membutuhkan beras atau sabun, orang itu mau datang ke toko atau ke pasar. Namun jika orang membutuhkan surat kabar, kecil kemungkinannya untuk mau datang ke kiosa atau agen surat kabar 
apapalagi harus setiap hari. Mereka lebih suka menunggu di rumah, menunggu pengantaran dari loper koran. Karena itu mereka lebih suka menjadi pelanggan koran karena kedatanganya lebih pasti, konsumen tidak perlu repot, dan harganya pun lebih murah.

Dalam hal promosi, perusahaan surat kabar, juga punya karakteristik yang berbeda dari bisnis komoditi lainnya. Sebab surat kabar, selain menjual berita kepada pembacanya, juga menjual space ( sebagian ruang atau halamannya untuk pemasang iklan). Karena itu, bagi perusahaan penerbitan yang sudah besar, jarang sekali yang beriklan di media massa lain. Jika suatu ketika beriklan, perusahaan surat kabar itu biasanya berikłan di dalam korannya sendiri.

\section{TEORI EFEKTIFITAS ORGANISASI}

Perubahan bauran pemasaran terkait langsung dengan efektifitas organisasi. Keberhasilan Jawa Pos memperoleh penghargaan Top Marketing 1998 dari The Bussiness Inside Mark Plus Jakarta, merupakan bukti betapa efektifnya perubahan bauran pemasarar. dalam meningkatkan kinerja perusahaan.

Harian Jawa Pos bisa berkelit dari deraan badai krisis ekonomi 2001 yang cukup berat ini. Perubahan bauran pemasaran perusahaan yang kini berkantor di Graha Pena Jalan A. Yani No. 88 Surabaya ini, sangat efektif dimana saat banyak perusahaan bangkrut, di saat daya beli masyarakat kian menurun, justru PT Jawa Pos Surabaya bisa meningkatkan jumlah pembacanya dan profitabilitasnya. 
Untuk menjelaskan efektifitas organisasi PT Jawa Pos, akan digunakan teori sebagai berikut:

Robbin (1994: 53-55), menjelaskan tentang efektifitas organisasi, yang didefinisikan sebagai sejauh mana sebuah organisasi mewujudkan tujuan-tujuannya. Namun tidak ada kesepakatan umum mengenai arti sebenarnya dari efektifitas organisasi. Di dalam definisi tersebut tersembunyi makna ganda yang sangat membatasi penelitian mengenai subyek tersebut maupun kemampuan para manajer untuk menangkap arti dan menggunakan konsep tersebut. Misalnya tentang tujuan, tujuan jangka panjang atau pendek, tujuan resmi organisasi atau tujuan aktual.

Keaneka ragaman organisasi serta minat para penilai atau peneliti yang berbeda-beda, mengakibatkan kesulitan untuk mendefinisikan secara persis tentang efektifitas organisasi. Oleh karena itu, efektifitas organisasi dirumuskan dalam bentuk kriteria. Hal tersebut di atas dirinci lebih lanjut oleh Robbins, (1997: 65-79), yang menguraikan tentang ukuran efektifitas organisasi melalui tiga pendekatan, yaitu:

a. Ukuran keefektitan sistem, yang meliputi: (1) profitabilitas, (2) perputaran persediaan, (3) volume penjualan, (4) perubahan modal kerja.

b. Ukuran keefektifan konstituensi strategis, yang meliputi: (1) profitabilitas dan pertumbuhan (bagi pemilik), (2) kompensasi dan tunjangan tambahan yang bersaing, kepuasan pada kondisi kerja dan kesediaan untuk melakukan tawar menawar (bagi pegawai dan serikat pegawai), (3) kepuasan terhadap harga, kualitas dan pelayanan (bagi pelanggan), (4) kepuasan terhadap pembayaran 
dan potensi penjualan masa datang (bagi pemasok), (5)

kemampuan untuk membayar hutang (bagi kreditur), (6) tidak menimbulkan kerusakan lingkungan, keikutsertaan pada organisasi lokal (bagi masyarakat lokal), (7) tunduk kepada hukum, menghindari dan denda (bagi lembaga pemerintahan).

c. Ukuran keefektifan berdasarkan nilai-nilai bersaing, yang meliputi: (1) fleksibilitas (mampu menyesuaikan diri terhadap perubahan kondisi, (2) perolehan sumber (mampu meningkatkan dukungan dari luar dan memperluas jumlah tenaga kerja), (3) perencanaan (tujuan jelas dan dipahami dengan benar), (4) produktifitas dan efisiensi (volume keluaran tinggi dan rasio keluaran terhadap masukan tinggi), (5) ketersediaan informasi (pemberian informasi yang mempengaruhi pekerjaan), (6) stabilitas (kontinyuitas, kegiatan lancar, perasaan tenteram), (7) tenaga kerja yan ¡ kohesif dan terampil (saling mempercayai dan menghormati, bersedia bekerja sama), mempunyai keterampilan dan kapasitas melakukan pekerjaan.

Dalam penelitian ini tidak seluruh ukuran efektifitas sebagaimana dijelaskan Robbins digunakan, akan tetapi didasakan pada data yang terkumpul dari PT Jawa Pos, maka ukuran efektifitas yang akan digunakan dalam penelitian ini adalah ukuran efektifitas sistem yang meliputi: (1) profitabilitas, (2) perputaran persediaan, (3) volume penjualan, (4) perubahan modal kerja.

Ukuran efektifitas profitabilitas dan volume penjcalan bisa dilihat dari jumlah pelanggan yang dimiliki PT Jawa Pos. Kecenderungan dari jumlah 
pelanggan itu naik atau menurun. Kalau kecenderungan jumlah pelanggan setelah dilakukan perubahan itu naik, berarti ukuran efektifitas yang digunakan menunjukkan indikasi positif. Tetapi jika setelah perubahan jumlah pelanggan menurun berarti efektifitas dari perubahan menunjukkan indikasi kegagalan.

Naiknya jumlah pelanggan akan berokorelasi positif dengan kenaikan jumlah laba yang diperoleh PT Jawa Pos. Besarnya laba yang diperoleh PT Jawa Pos akan sangat mempengaruhi efektifitas untuk ukuran perubahan modal. Dengan naiknya laba maka bagian laba yang disimpan perusahaan akan lebih besar sehingga struktur modal yang dimiliki PT Jawa Pos semakin kuat.

Khusus mengenai indikator perputaran persediaan, tidak relevan dalam penelitian ini karena PT Jawa Pos menerapkan inventory just in time sehingga semua produk koran PT Jawa Pos dijual hari itu juga. Sistem yang diterapkan di PT Jawa Pos seperti itu tidak memungkinkan terjadinya stock okname sehingga indikator perputaran persediaan tidak relevan digunakan dalam penelitian ini.

Penentuan efektifitas sistem di PT Jawa Pos ini sudah disesuaikan dengan orientasi tujuan penelitian ini yaitu menilai sejauhmana pelaksanaan perubahan bauran pemasaran penerbitan Pers PT Jawa Pos dalam mengendalikan, memperbaiki serta meningkatkan efektifitas perusahaan. 


\section{BAB III}

\section{KERANGKA KONSEPTUAL DAN PROPOSISI THESIS}




\section{BAB III}

\section{KERANGKA KONSEPTUAL DAN PROPOSISI THESIS}

\section{A. MODEL PENGELOLAAN PERUBAHAN}

Dalam penelitian evaluasi perubahan bauran pemasaran penerbitan pers untuk meningkatkan efektifitas perusahaan PT Jawa Pos, akan diteliti berdasarkan analogi model teori pengelolaan perubahan dari Robbbins, sebagai berikut:

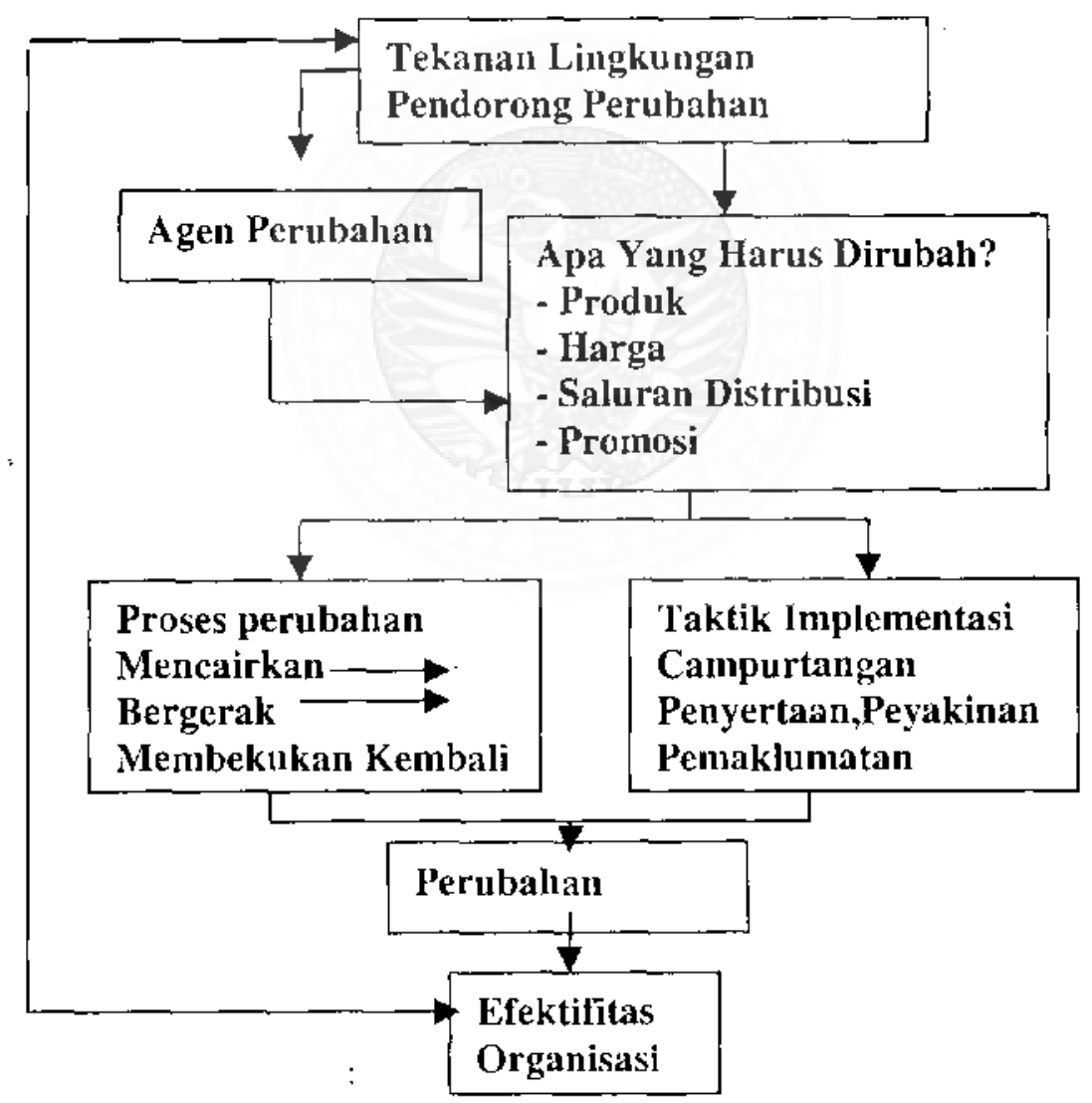

Gambar: 3.01: Model perubahan

Sumber: Robbins (1994: 422) 
Fenomena tekanan lingkungan organisasi (eksternal maupun kondisi internal) menyebabkan kinerja perusahaan mengałarni penurunan secara terus menerus sehingga membahayakan kelangsungan perusahaan. Untuk mengatasi masalah tersebut, perusahaan memutuskan dilakukan perubahan terhadap bauran pemasaran.

Perubahan terhadap bauran pemasaran dilakukan karena dalam bauran pemasaran terdapat seperangkat alat-alat pemasaran yang digunakan perusahaan untuk mengejar tujuan pemasarannya sesuai dengan target pasar yang telah ditetapkan. Perubahan ini dirumuskan dalam suatu perencanaan strategik pemasaran, untuk memastikan bahwa tujuan-tujuan dan strategi-strategi pemasaran bisa diarahkan pada pencapaian target korporat perusahaan, melalui peningkatan efektifitas organisasi.

Elemen-elemen bauran pemasaran yang dirubah adalah produk (product), antara lain menyangkut variasi, kualitas, desain, ciri-ciri khusus, nama merek, ukuran, layanan dan jaminan. Elemen harga (orice) meliputi pemberian diskon, cara dan waktu pembayaran. Elemen distribusi atau tempat (place) menyangkut jaringan (chinel), jangkuan pelayanan, tempat, persediaan (stock), dan saran angkutan. Sedangkan elemen promosi (promotion) menyangkut sales, promotion, advestising, sales force, oublic relations, and direct marketing.

Komponen atau unsur-unsur dalam bauran pemasaran PT Jawa Pos harus dipadukan dalam satu tindakan. Sebab, masing-masing komponen akan bisa mempengaruhi pembeli. Jika manajemen tidak padu maka akan 
dimungkinkan terjadi konflik sehingga perubahan bauran pemasaran yang dilakukan akan sia-sia. Sebagai contoh, jika pesan iklan dalam tampilannya menekankan pada kualitas, sementara tenaga penjual mengutamakan harga rendah, maka pembeli akan bingung. Brand image PT Jawa Pos juga akan bisa terpengaruh.

Dalam bauran pemasaran PT Jawa Pos, harga memegang peranan penting dalam penempatan suatu sura kabar. Pembeli atau calon pembeli biasanya punya banyak pilihan soal harga produk sejenis. Pada sisi lain, jika suatu surat kabar atau harian pagi dijual jauh lebih murah dari pada harga produk sejenis, sebagian pembeli malah akan meragukan kualitas produk yang dijual dengan harga lebih murah itu. Namun sebaliknya, jika suatu produk ditetapkan dengan harga lebih tinggi dari pada produk sejenis, sebagian calon pembeli akan menilai bahwa produk yang dijual lebih mahal itu kualitasnya lebih bagus dibanding dengan produk sejenis yang harganya lebih murah. Tetapi, yang perlu juga diingat, jika harga yang ditawarkan selalu tinggi mungkin sebagian calon pembeli juga menolaknya jika memang harga itu tidak sesuai dengan kualitas atau nilai produk yang mereka beli.

Untuk melaksanakan perubahan berbagai komponen bauran pemasaran kemudian direalisasikan dalam satu tindakan, perusahaan perlu membentuk agen perubahan. Agen perubahan ini adalah mereka yang memegang posisi kunci di perusahaan. Ėiasanya posisi ini ditempati oleh eksekutif senioi, manajer unit utama. Yang termasuk di dalamnya adalah konsultan dari luar yang dibawa ke dalam. Setelah ditetapkan siaṕ yang menjadi agen 
perubahan dan telah ditetapkan apa yang harus diubah, maka selanjutnya kita perlu memperhatikan bagaimana melaksanakan perubahan tersebut.

Agar proses perubahan bisa berjalan sesuai dengan yang direncakan, maka perubahan membutuhkan pencairan (unfreezing) status quo, perpindahan (moving) ke keadaan yang baru, dan pembekuan kembali (refreezing) perubahan tersebut agar menjadi permanen. Selanjutnya, proses perubahan pada tahap implementasi adalah menetapkan keputusan mengenai taktik apa yang akan digunakan untuk melakukan perubahan yang direncanakan tersebut. Taktik tersebut meliputi intervention, participation, persuasion, dan edict.

Dalam penelitian evaluasi ini digunakan peridekatan Yin (2002: 29), dimana dalam pendekatan tersebut akan digunakan proposisi penelitian. Proposisi merupakan jawaban teoritik terhadap masalah penelitian, oleh karena itu harus mencerminkan isu-isu teoritis penelitian yang dirumuskan berdasarkan teori tentaing proses perubahan, bauran pemasaran serta efektifitas organisasi. Dengan demikian, dalam penelitian evaluasi ini proposisi berfungsi sebagai kriteria penilaian sekalis 'us sebagai pengarah penelitian untuk menjawab masalah penelitian.

Sebagai kriteria penilaian maka apabila proses perubahan terdapat kesamaan (kesesuaian) dengan proposisi, maka perubahan tersebut secara teoritik dapat dinyatakan benar. Kriteria penilaian dapat pula berupa teori atali hal-hal pragmatis yang ditentukan oleh obyek penelitian. 
Apabila kriteria penilaian yang ditentukan itu benar atau terdapat kesesuaian, berarti efektifitas organisasi sebagaimana bisa dilihat pada gambar di atas dapat tercapai. Tercapaianya efektifitas organisasi sesuai dengan kriteria yang ditetapkan peneliti akan memberikan umpan balik, sekaligus jawaban terhadap tekanan lingkungan eksternal yang mendorong terjadinya perubahan bauran pemasaran.

\section{B. PROPOSISI PENELITIAN}

Berdasarkan hubungan antara teori-teori tersebut, maka rumusan proposisi penelitiannya adalah sebagai berikut:

a. Apabila tekanan lingkungan organisasi mengakibatkan penurunan prestasi organisasi secara terus menerus maka organisasi akan melakukan perubahan bauran pemasaran.

b. Agar perubahan bauran pemasaran dapat terlaksana secara terencana, terarah dan sesuai dengan target yang ditetapkan, maka diperlukan formalisasi proses perubahan dengan mengikut sertakan kekuatan dominan organisasi sebagai agen (penanggung jawab) dan pelaksana perubahan.

c. Apabila proses perubahan tidak disosialisasikan dan diimplementasikan sesuai dengan kultur dan tujuan karyawan akan memunculkan ketegangan dan konflik. Oleh karenanya diperiukan jalan tengah untuk menyelesaikan hambatan dan konflik tersebut. 
d. Apabila perubahan bauran pemasaran dapat dilakukan secara tepat dengan melibatkan elemen-elemen bauran pemasaran, maka akan mampu meningkatkan efektifitas organisasi. Oleh karenanya, diperlukan kerjasama yang sinergis antar departemen/divisi dalam perusahaan penerbitan pers. 


\section{BAB IV}

\section{METODE PENELITIAN}




\section{BAB IV}

\section{METODE PENELITIAN}

Perubahan lingkungan eksternal krisis ekonomi sangat mempengeruhi kenerja PT Jawa Pos. Karena pengaruhnya yang signifikan terhadap kenerja perusahaan, maka perubahan lingkungan eksternal itu harus ditanggai oleh setiap level manajemen yang ada di dalam PT Jawa Pos.

Depresiasi nilai rupiah sangat memperangi harga bahan baku sehingga mengalami lonjakan harga. Melonjaknya harga bahan baku PT Jawa Pos menyebabkan manajemen F T Jawa Pos harus sangat hati-hati dalam melakukar, keputusan untuk menyiasati keadaan yang serba sulit. Indikasi sulitnya situasi itu bisa dilihat dari menurunya volumen penulajan sejak krisis ekonomi.

Berbagai langkah perubahan dilakukan untuk menyesuaikan dengan kondisi krisis ekonomi. Perubahan itu mencakup semua aspek dalam bauran pemasaran yaitu product (produk), price (harga), place (tempat atau saluran distribusi), dan promotion (promosi). Semua elemen dalam bauran pemasaran itu dikombinasikan menjadi satu tindakan agar bisa dicapai efektifitas organisasi sebagaimana ditargetkan dalam perencanaan perubahan bauran pemasaran.

Agar dalam proses perubahan itu tidak melahirkan konflik maka perubahan yang ada dalam PT Jawa Pos melibatkan kekuatan dominan dan disosialisasikan kepada seluruh unsur yang ada dalam perusahaan. Sosialisasi memegang peranan penting, terutama dalam hal mengkomunikasikan perencanaan perubahan bauran pemasaran kepada semua bagian yang merupakan elemen dari bauran pemasaran. Dari sosialisasi ini kemudian 
masing-masing bagian atau departemen akan tahu arah dan tujuan dari perubahan sehingga konflik bisa dihindari dan sinergisitas tindakan untuk mencapai efektifitas organisasi bisa dicapai.

Berbagai perubahan unsur bauran pemasaran terbukti efektif untuk meningkatkan kinerja perusahaan PT Jawa Pos. Hal iłu bisa dilihat dari meningkatnya volumen penjualan PT Jawa Pos setelah perubahan bauran pemasaran dilakukan. Fonomena seperti inilah yang menjadi pertimbangan penting untuk menjadikan PT Jawa Pos sebagai obyek penelitian.

Untuk mencapai tujuan penelitian bauran pemasaran pada PT Jawa Pos, maka dirumuskan metodologi penelitian sebagai berikut;

1. Metode Studi

Penelitian evaluasi ini menggunakan metode studi kasus eksploratoris. Untuk menjamin validitas penelitian, digunakan replika studi kasus tunggal, Penggunaan replika studi kasus tunggal ini untuk memenuhi uji validitas penelitian, yaitu untuk menjamin bahwa seluruh laıgkah penelitian sampai dengan perolehan data dan temuan dapat dipertanggungjawabkan kebenarannya. Kegunaannya agar data dan temuan tersebut dapat divisualisasikan dan digeneralisasikan (generalisasi analitik, bukan generalisasi statistik).

2. Jenis Data

Data yang digunakan dalam penelitian ini melului berbagai sumber yang berbeda yaitu; 
a. Data Primer.

Data yang diperoleh melalui wawancara langsung dengan pimpinan PT. Jawa Pos Surabaya dengan cara berstruktur (daftar pertanyaan) dan tak berstruktur (Spontanitas).

Data ini terdiri dari :

1. Tanggapan dari jimpinan PT. Jawa Pos Surabaya terhadap biaya produksi Koran.

2. Tanggapan dari pimpinan PT. Jawa Pos Surabaya terhadap Fasilitas kantor.

3. Tanggapan dari pimpinan PT. Jawa Pos Surabaya terhadap letak gedung .

4. Tanggapan dari pimpinan PT. Jawa Pos Surabaya terhadap lingkungan.

5. Tanggapan dari pimpinan PT. Jawa Pos Surabaya terhadap perubahan Bauran pemasaran.

\section{b. Data Skunder}

Data yang diperoleh melalui penelitian perpustakaan untuk mendapatkan teori-teori dan fakta-fakta yang mendukung strategi bauran pemasaran yang dilakukan PT. Jawa Pos Surabaya untuk menghadapi krisis ekonomi. 
Datanya meliputi :

1. Dokumen.

Jenis dokumen dalam kasus ini antara lain surat keputusan, pengumuman resmi, laporan kemajuan PT Jawa Pos, serta kliping atau artikel yang muncul di media massa, tentang hal yang berkaitan pada topik penelitian.

2. Rekaman Arsip.

Rekaman arsip (seringkali dalam bentuk komputerisasi) terdiri atas layanan jumlah pemasok, pelanggan, anggaran pada periode tertentu, daftar komoditi dan performance organisai.

3. Prosedur Pengumpulan Data

a. Penelitian Pendahuluan

Penelitian diawali dengan melakukan pengamatan dan penelitian pendahuluan di perusahaan untuk dapat memperoleh gambaran yang dihadapi perushaan secara lengkap dan jelas.

b. Penelitian Lapangan

Penelitian ini dilakukan dengan mengadakan wawancara secara langsung kepada pimpinan PT Jawa Pos. Wawancara merupakan sumber informasi yang esensial bagi studi kasus ini. Tipe wawancara yang akan dilaksanakan adalah Open-ended. Wawancara yang akan ditujukan kepada responden kunci untuk memperoleh fakta-fakta, di samping opini dari responden kunci 
tersebut. Responden kunci adalah yang mempunyai peran besar dalam keberhasilan perubahan bauran pemasaran PT Jawa Pos. Namun demikian, akan dihindari ketergantungan pada responden kunci, karena tidak menutup kemungkinan terdapat pengaruh hubungan antar pribadi atau subyektifitas.

Selain itu juga dilakukan wawancara terfokus. Dalam wawancara ini, dilakukan dengan menyampaikan pertanyaan-pertanyaan spesifik untuk mendukung fakta-fakta tertentu. Dalam wawancara ini sejauh mungkin akan digali komentar yang segar dan orisinal dari responden. Tipe wawancara bisa open-ended, tidak harus mengikuti secara ketat serangkaian pertanyaan yang diturunkan dari perumusan masalah penelitian.

\section{Teknis Analisa}

Data yang sudah diperoleh atau dikumpulkan lalu diklasifikasi menurut jenisnya. Untuk mencapai tujuan penelitian ini maka dipandang perlu dilakukan analisa terhadap keseluruhan data yang sudah berhasil dihimpun selama penelitian. Baik yang menyangkut data kualitatif maupun yang kuantitatif.

Analisa itu dilakukan dengan mengkomparasikan antara peristiwa empirik yang disusun secara kronologis dengan kronologi teoritik (proposisi) yang telah dirumuskan sebelumnya.

Skema analisis studi kasus secara kronologis adalah sebagai berikut : 
KRONOLOGI

TEORITIK

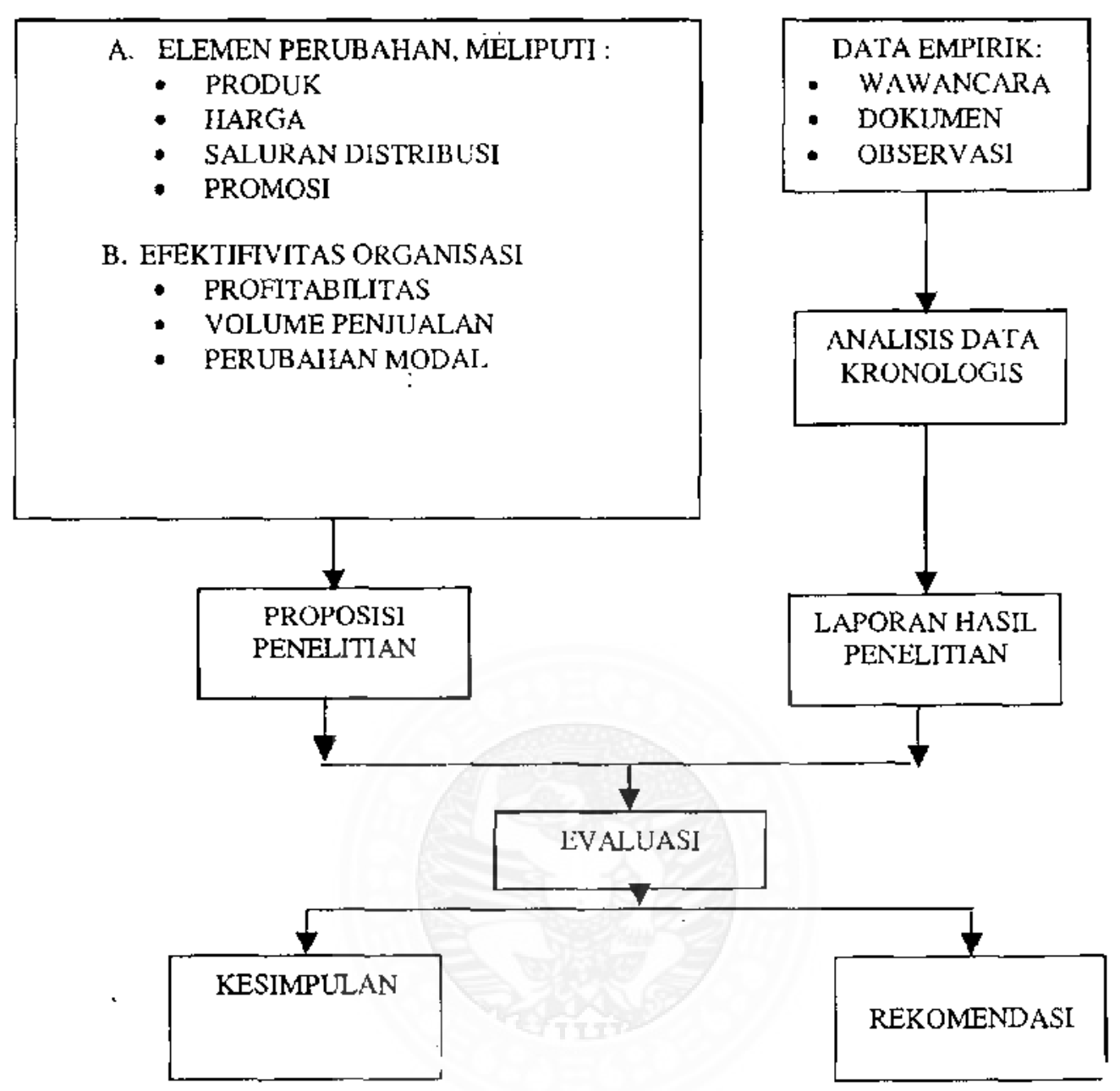

Gambar : 4.02 : Pola Analisis Kronologis

Sumber : disusun peneliti

Penjelasan gambar bagan tersebut di atas adalah sebagai berikut :

a. Kronologi empirk adalah susunan peristiwa empirik yang diperoleh dari penelitian yang diawali dengan proses pengumpulan data dan analisis data secara kronologis yang secara keseluruhan dituangkan dalam laporan hasil penelitian. Laporan penelitian ini digunakan sebagai bahan 
untuk menyusun evaluasi peristiwa empirik yang dibandingkan dengan proposisi penelitian.

b. Evaluasi adalah proses verifikasi dengan kriteria yaitu membandingkan antara kronologi empirik dengan proposisi penelitian atau langsung pada teori yang digunakan dalam penelitian. Hasil evaluasi adalah peristiwa dinyatakan mempunyai kesesuaian atau tidak dengan proposisi sehingga secara teoritik dapat dinyatakan benar atau salah (baik atau buruk). Lebih lanjut untuk menilai proses perubahan yang telah dilaksanakan adalah dengan melakukan analisis dampak perubahan yang telah dilaksanakan. Analisis ini hanya dilakukan dari sudut pandang teoritik berdasarkan landasan teori yang digunakan.

Selain itu juga digunakan analisis SWOT (Strenght), (Weaknesses), (Opportunity), and (Treats) yaitu kekuatan, kelemahan, peluang dan ancaman (Freedy Rangkuti, 2001, hal. 18). Lewat analisis ini akan diungkapkan apa saja kekuatan yang dipakai PT. Jawa Pos Surabaya untuk menghadapi krisis ekonomi, apa kelemahan yang perlu dihilangkan, ancamait yang harus diatasi, dan peluang apa saja yang seharusnya bisa dimanfaatkan. 


\section{BAB V}

\section{EVALUASI PERUBAHAN BAURAN PEMASARAN UNTUK MENINGKATKAN EFEKTIVITAS ORGANISASI}




\section{BAB V}

\section{EVALUASI PERUBAHAN BAURAN PEMASARAN UNTUK MENINGKATKAN EFEKTIVITAS ORGANISASI}

Dalam penelitian evaluasi perubahan bauran pemasaran PT Jawa Pos untuk meningkatkan efektifitas organisasi, dilakukan pembandingan antara kronologi teoritik yang tertuang dalam proposisi penelitian dengan proses empirik perubahan, yang dapat dilihat sebagai berikut :

1. Perbandingan proposisi pertama dengan faktor pendorong perubahan perusahaan.

Proposisi Utama :

Apabila tekanan lingkungan organisasi mengakibatkan penurunan prestasi organisasi secara terus menerus maka organisasi akan melakukan perubahan bauran pemasaran.

Perubahan terhadap bauran pemasaran dilakukan karena dalam bauran pemasaran terdapat seperangkat alat-alat pemasaran yang digunakan perusahaan untuk mengejar tujuan pemasarannya sesuai dengan target pasar yang telah ditetapkan. Perubahan ini dirumuskan dalam suatu perencanaan strategik pemasaran, untuk memastikan bahwa tujuan-tujuan dan strategi-strategi pemasaran bisa diarahkan pada pencapaian target korporat perusahaan, melalui peningkatan efektifitas organisasi. 
Proses empirik diputuskannya perubahan adalah sebagai berikut: dari laporan hasil penelitian dokumen, arsip dan wawancara dapat dirumuskan faktor-faktor dominan penyebab perubahan adalah :

Adanya tekanan lingkungan yang bersumber pada krisis moneter 1997 menjadi tanda tanya besar bagi Harian Jawa Pos. Ketika itu posisi bisnis Jawa Pos belum begitu mantap. Kemampuan keuangannya masih terus digerogoti oleh kewajiban - kewajiban yang timbul untuk investasi membesarkan Jawa Pos itu sendiri di masa lalu. Misalnya, untuk membeli mesin - mesin cetak termodern yang tentu dengan cara leasing atau kredit.

Lebih dari jtu Jawa Pos juga baru saja melahirkan anak-anak perusahaan yang banyak sekali jumlahnya dan luas sekali jangkauannya. Terlihat posisi Jawa Pos memang sangat rawan terhadap badai krisis yang sangat hebat. Begitu banyak sisi negatif yang bisa membuat Jawa Pos rapuh di tengah badai tersebut. Di samping itu perusahaan mempunyai kendala internal yang cukup besar antara lain, melonjaknya harga bahan baku sejerti kertas, tinta dan biaya pemeliharaan peralatan produksi.

Atas tekanan lingkungan dan kondisi internal tersebut, perusahaan selama beberapa tahun berturut-turut merugi dan tidak mampu membayar kewajiban (pinjaman). Tekanan lingkungan dan penurunan prestasi keuangan tersebut telah diidentifikasi akan mengancarn kelangsungan operasi perusahaan. 
Atas kondisi tersebut perusahaan kemudian melakukan perubahan bauran pemasaran yang meliputi semua unsur dalam bauran pemasaran yaitu produk, harga, saluran distribusi dan promosi. Dengan melakukan perubahan tersebut perusahaan sedang berusaha meminimalisasi ketidakpastian usaha. Dengan demikian nampak bahwa proposisi pertama mempunyai kesesuaian dengan kondisi empirik keputusan perubahan bauran pemasaran dalam PT Jawa Pos.

Secara teoritik, keputusan dilakukan perubahan dalam aspek yang cukup luas telah benar menurut teori Robbins sebagai jalan untuk mengatasi lingkungan yang mengakibatkan prestasi organisasi mengalami penurunan secara terus menerus, sehingga organisasi akan melakukan perubahan menyeluruh terhadap semua elemen bauran pemasaran.

2. Perbandingan proposisi ke dua dengan pembentukkan agen perubahan. Proposisi Kedua :

Agar perubahan bauran pemasaran dapat terlaksana secara terencana, terarah dan sesuai dengan target yang ditetapkan, maka diperlukan formalisasi proses perubahan dengan mengikutsertakan kekuatan dominan organisasi sebagai agen (penanggung jawab) dan pelaksana perubahan. 
Proses empirik terjadinya perubahan dalam perusahaan adalah sebagai berikut: proses perubahan bauran pemasaran dalam perusahaan, dimulai sejak adanya penjelasan khusus dari CEO PT Jawa Pos Dahlan Iskan tentang bahaya-bahaya dari krisis moneter yang terjadi saat itu. Dari penjelasan bahaya krisis ini kemudian CEO PT Jawa Pos Dahlan Iskan memberikan langkah-langkah solusi yang perlu diambil perusahaan untuk menyelamatkan masa depan bisnis Jawa Pos.

Penjelasan dari CEO itu kemudian diperinci dalam bentuk menetapkan kebijakan pokok yang melibatkan jajaran direktur utama, seluruh direksi dan manajer. Di sini juga ditekankan pentingya melakukan evaluasi pelaksanaan perubahan serta memberikan informasi yang diaggap perlu demi kelancara proses perubahan bauran pemasaran dalam perusahaan.

Dengan demikian proses perubahan yang terjadi di Jawa Pos melalui pembentukan agen seperti tersusun dalam proposisi penelitian. Agen perubahan itu langsung dimotori oleh CEO PT Jawa Pos Dahlan Iskan, dengan memberikan pengarahan tentang langkah-langkah yang perlu diambil untuk menyiasati krisis moneter.

Proses perubahan bauran pemasaran itu telah mielibatkan unsurunsur dominan dalam perusahaan, yang bisa memberikan kemungkinan keberhasilan proses perubahan yang cilperlukan untuk mempertahankan kelangsungan hidup perusahaan. Pelibatan unsur-unsur dalam perusahaan dilakukan melalui sosialisi yang intensif sehingga perusahan 
bauran pemasaran dapat terlaksana secara terencana, terarah sesuai dengan target yang ditetapkan.

3. Perbandingan proposisi ketiga dengan konflik dalam perusahaan.

Proposisi Ketiga :

Apabila proses perubahan tidak disosialisasikan dan diimplementasikan sesuai dengan kultur dan tujuan karyawan akan memunculkan ketegarigan dan konflik. Oleh karenanya diperlukan jalan tengah untuk menyelesaikan hambatan dan konflik tersebut.

Kondisi empirik perubahan bauran pemasaran dan efektifitas organisasi adalah sebagai berikut :

Sejak ada penjelasan khusus dari CEO Jawa Pos Dahlan Iskan tentang bahaya krisis moneter sejak tahun 1997, maka proses pencairan status quo (unfreezing) organisasi perusahaan dimulai. Tindak lanjutnya kemudian dilakukkan berbagai perubahan yang diperlukan untuk menyelematkan Jawa Pos dari badai krisis moneter.

Dari sana kemudian pelaksanaan perubahan dimulai (moving). Hasil dari perubahan tersebut adalah perubahan struktur organisasi, mempertegas kewenangan (otonomi) departemen menjadi profit centre, perubahan sistem kompensasi, proses manajerial, dan pengukuran efektifitas perusahaan serta perubahan susunan dan komposisi karyawan (refreezing). 
Sedang taktik Implementasi perubahan dilakukan dengan cara memperbanyak menggunakan forum resmi baik berupa rapat resmi perusahaan maupun forum-forum lain yang dibentuk untuk sosialisasi dan menampung berbagai pendapat dari karyawan manajemen maupun operasional. Dengan taktik implementasi tersebut diatas, nampak bahwa perusahaan menggunakan cara partisipatif dan persuatif. Forum konsultatif juga dilakukan, dimana forum ini merupakan forum untuk sosialisasi dan mencari kompromi-kompromi, bisa mengakibatkan perubahan target, dan jadwal perubahan. Cukup banyak kompromikompromi dilakukan (khususnya yang berkaitan dengan karyawan) sehingga tidak banyaik menimbulkan gejolak dan keresahan diantara para karyawan.

Cara yang tempuh tersebut menjadikan pros es perubahan bauran pemasaran menjadi berjalan secara perlahan karena banyak program perubahan bauran pemasaran yang harus direvisi agar sesuai dengan kondisi dan kultur yang berlangsung pada saat itu. Namun hal tersebut menjadikan tingkat konflik dapat dibatasi.

Dengan demikian nampak kesesuaian antara proposisi keempat dengan proses perubahan yang dilaksanakan pada perusahaan, meskipun waktu yang dibutuhkan ternyata cukup panjang. Secara teoritik, proses dan taktik perubahan telah benar menurut teori Robbins tentang proses dan taktik implementasi perubahan, yaitu melaluj unfreexing, 
moving, refreesing, dan taktik implementasi dengan menggunakan cara partisipatif dan persuasif.

4. Perbandingan proposisi keempat dengan perubahan bauran pemasaran PT Jawa Pos.

Proposisi Utama :

Apabila perubahan bauran pemasaran dapat dilakukan secara tepat dengan melibatkan elemen-elemen bauran pemasaran, maka akan mampu meningkatkan efektifitas organisasi. Oleh karenanya, diperlukan kerjasama yang sinergis antar departemen/divisi dalam perusahaan penerbitan pers.

Proses empirik terjadinya perubahan unsur-unsur bauran pemasaran dalam perusahaan adalah sebagai berikut:

a. Mengubah Jumlah dan Ukuran Halaman

Untuk menghadapi krisis ekonomi 2001, manajemen PT. Jawa Pos menerapkan beberapa kebijaksanaan yang berkaitan dengan produknya. Antara lain mengubah ukuran koran dan mengurangi jumlah halaman. Ukuran koran yang semula terdiri atas sembilan kolom setiap halaman, dipersempit menjadi tinggal tujuh kolom. Sedangkan jumlah halaman koran yang semula 24 halaman setiap hari dikurangi menjadi tinggal 20 halaman. dan bahkan akhimya tinggal 16 halaman.

Pengurangan dan penyempitan halaman ini dilakukan dengan pertimbangan bahwa harga kertas koran selama 2001 tidak stabil, 
mengalami kenaikan beberapa kali seiring dengan fluktuasi nilai tukar dolar Amerika Serikat terhadap rupiah. Dengan pengurangan dan penyempitan halaman, perusahaan ini bisa melakukan efisiensi penggunaan kertas. Dengan demikian ada efisiensi dalam bidang produksi.

Pertimbangan lain mengapa efisiensi penggunaan kertas itu dilakukan karena manajemen menganggap tidak mungkin menaikkan hargajual koran saat itu, meski harga bahan baku produksinya naik tajam. Manajemen memandang sangat tidak realistis jika kenaikan harga kertas itu dibebankan secara langsung kepada pelanggan dengan cara menaikkan harga jual koran yang ekuivalen der gan kenaikan harga kertas koran. Sebab saat itu masyarakat sedang dilanda krisis ekonomi. Dan lagi, perusahaan pers yang lain, termasuk juga surat kabar pesaing, saat itu tidak menaikkan harga produknya.

Saat harga kertas naik tajam seiring dengan naiknya kurs dollar terhadap rupiah, PT Jawa Pos sempat mengalami kerugian bes ar dari hasil penjualan produknya (koran). Sebab biaya produksi naik, sementara perusahaan tidak segera bisa menaikkan harga jual produknya karena pertimbangan seperti disebut di atas.

Pada periode 1 Januari 2001 hingga akhir Mei 2001, misalnya harga langganan koran Jawa Pos adalah R-p 50.000 per bulan. Harga jual dari penerbit (perusahaan) ke agen adalah Rp 820 per eksemplar. Padahal, ongkos cetak atau biaya produksinya di atas hargajual ke agen itu. 
Sebagai contoh, pada 1 Januari 2001, ongkos cetak adalah Rp 868 per eksemplar. Pada 8 Januari 2001, ongkos cetak itu naik menjadi Rp 1.028 per eksemplar, pada 20 Januari naik menjadi $\mathrm{Rp} 4.005$ per eksemplar, dan pada 22 Januari turun menjadi Rp 1.040 per eksemplar.

Naik turunnya ongkos cetak (terutama biaya kertas, tinta dan percetakan) itu karena kurs dolar yang saat itu sangat tidak stabil. Pada 6 Maret 2001, misalnya ongkos cetak mencapai Rp 995 per eksemplar. Pada 19 Maret turun menjadi Rp 827, pada 26 Maret 742, pada 30 Maret Rp 740 dan dalam April 2001 ongkos cetak berkisar pada angka Rp 707 per eksemplar. Saat ongkos cetak mencapai di atas Rp 800 per eksemplar, perusahaan Jawa Pos mengatami kerugian dari penjuaian korannva. Sebab, ongkos cetaknya lebih mahal dari pada harga jual korannya. Baru ketika ongkos cetak di bawah Rp 800 per eksemplar, perusahaan mendapatkan laba dari hasil penjualan koran. Karena itu, pengurangan dan penyempitan halaman itu dimaksudkan untuk mengurangi pemakaian kertas. Dengan demikian perusahaan bisa menekan ongkos produksinya.

b. Meningkatkan Kualitas Berita

Perubahan lain yang menyangkut produk ialah bahwa manajemen PT Jawa Pos bekerja keras untuk meningkatkan kualitas berita-berita yang disuguhkan kepada pelanggannya. Manajemen menyadari bahwa dengan pengurangan dan penyempitan halaman maka porsi berita yang 
disuguhkan kepada pelanggannya juga berkurang. Apalagi jika ruang atau halaman yang sudah berkurang itu juga digunakan untuk iklan.

Menyadari kondisi seperti itu, manajemen perusahaan berjuang keras untuk melakukan perubahan kualitas berita. Caranya, di bagian redaksi kian selektif terhadap berita-berita yang akan dimuat atau diturunkan. Dengan cara ini manajemen berharap pembaca tetap terpuaskan oleh sajian beritanya.

Untuk meningkatkan kualitas berita tersebut, manajemen melakukan berbagai langkah. Diantaranya melakukan penyegaran terhadap bagian redaksi. Bagian redaksi, mulai dari reporter hingga redaktur diberi pengarahan. Intinya diingatkan kembali bagaimana mencari, menulis dan menurunkan berita yang berkualitas yang sekiranya bisa disenangi dan dibutuhkan masyarakat. Pengarahan dilakukan CEO PT Jawa POS Dahian Iskan setiap pagi di kantor selama beberapá minggu.

Selain itu, manajemen melakukan degradasi terhadap bagian redaksinya. Reporter yang dianggap kualitasnya rendah, dipindahkan ke bagian lain tapi masih di lingkungan perusahaan PT Jawa Pos dan sebagian lain dipindah-tugaskan ke perusahaan anak-anak perusahaan. Menurut Dahlan Iskan, diantara mereka ada yang ditugaskan untuk ikut membantu di SI (Suara Indonesia), koran Ekbis (Ekonomi Bisnis) anak perusahaan dan ada yang diperbantukan ke koran Malang Pos, koran anak perusahaan PT Jawa Pos, yang berbasis di Malang, Jatim. 
Karyawan PT Jawa Pos yang dipindah-tugaskan itu tidak seluruhnya karena terkena degradasi. Sebagian diantara mereka sebenamya dinilai berkualitas bagus dan tetap layak di PT Jawa Pos. Namun sejalan dengan prinsip perampingan (efisiensi tenaga) dan sekalig، ss mengoptimalkan kinerja karyawan di PT Jawa Pos, mereka yang berkualitas itu diminta untuk membenahi anak-anak perusahaan.

Sebagai koran harian yang menjual berita kepada pelanggannya, manajemen PT Jawa Pus sangat memperhatikan soal desain dan variasi produknya. Tujuannya agar pelanggan koran tetap menyukainya dan tidak merasa bosan. Karena itu, desain koran meski halamannya tetap berbentuk segi empat namun tata wajahnya bisa sering berubah. Hampir tiap hari ada perubahan kecil pada tata wajah. Begitu pula variasi beritanya. Adakalanya berita-berita politik yang mendominasi halaman koran, namun adakalanya berita-berita ekonomi atau kriminal atau olahraga yang mendominasinya.

\section{c. Meningkatkan Nilai Voucher}

Sebagai salah satu bentuk pemberian layanan dalam soal produk kepada pelanggan, manajemen PT Jawa Pos selama 2001 berupaya melakukan perubahan kualitas pelayanan kepada mereka (pelanggan). Selain kian memberikan kepastian bahwa jam kedatangan koran di tangan pernbaca lebih pagi, juga memberikan voucher kepada pelanggan yang menerima koran terlambat atau tidak menerima koran dari agen atau penyalurya. 
Pemberian voucher ini sebenarya sudah dilakukan sejak beberapa tahun Jalu namun selama 2001 nilainya ditingkatkan. Dari semula senilai $R p$ 1.000 ditingkatkan menjadi Rp 1.500 setiap satu kali tidak menerima koran. Ini artinya, bagi pelanggan koran Jawa Pos yang tidak menerima koran satu kali (satu hari) maka dia berhak mendapatkan voucher itu. Voucher akan diperhitungkan saat pembayaran uang langganan. Dan meski sudah mendapatkan voucher, bagi pelanggan yang tid.ak menerima koran bisa meminta ke bagian pengaduan pelanggan agar diberi koran pengganti pada hari itu juga. Pemberian koran pengganti ini bisa dilayani sekitar satu jam setelah adanya pengaduan.

d. Melakukan Diskriminasi tᄂarga

Selama 2001 manajemen Jawa Pos tercatat dua kali melakukan perubahan harga produknya. Mulai 1 Januari 2001 harga dinaikkan dari semula $\mathrm{Rp} 18.000$ per bulan untuk langganan menjadi $\mathrm{Rp} 20.000$. Kenaikan harga ini dimaksudkan untuk mengurangi kerugian yang terlalu besar bagi PT Jawa Pos akibat tingginya kenaikan harga kertas koran. Pada Juni 2001, perusahaan ini menetapkan harga baru langganannya menjadi $R p 25.000$ per bulan.

Tentang ongkos kirim ini, dalam kota rata-rata $\mathrm{Ap} 10$ per eksemplar. Namun untuk luar pulau misalnya Samarinda di Kalimatan Timur, ongkos kirim itu bisa mencapai Rp 400 per eksemplar. Karena itu, harga jual koran disana (harga ke agen), mencapai Rp 1.100 per eksemplar. 
Harga jual koran Jawa Pos, seperti disebut diatas, masih lebih tinggi dibanding dengan koran pesaingnya. Harga jual Jawa Pos yang cukup tinggi itu juga karena biaya operasionalnya tinggi, sementara biaya produksi maupun biaya operasional koran kompetitor tidak setinggi PT Jawa Pos. Antara lain, karena kompensasi yang diberikan manajemen kepada karyawannya, secara umum lebih tinggi (lebih baik) dibanding kompensasi yang diberikan perusahaan kompetitor kepada karyawannya.

Karena itu, selama 2001 manajemen Jawa Pos melakulan berbagai efisiensi. Misalnya memotong gaji direksi antara 15 persen hingga 25 persen, memotong tunjangan profesi redaksi hingga 50 persen, efisiensi dalam penggunaan telepon, melikuidasi sejumlah kantor biro (terutama di Jatim) dan mengurangi jatah rekening telepon untuk wartawan di daerahdaerah.

Saat gencar-gencarnya gerakan reformasi harga kertas koran tinggi, sementara harga jual koran lebih rendah dibanding dengan HPP-nya. Saat itu Jawa Pos mengalami kerugian jika hanya mengandalkan dari penjualan koran. Saat itu perusahaan mi menerapkan kebijaksanaan menekan oplah. Artinya, meskipun pada saat itu permintaan koran cukup tinggi, namun perusahaan kurang tertarik untuk memenuhi permintaan mereka itu. Sebab dalam perhitungan manajemen, menjual koran saat itu rugi.

Untuk menekan oplah itu, manajemen membatasi secara ketat terhadap jatah para agennya. Caranya, agen yang minta tambahan jatah, 
tidak dilarang, namun dikenai harga khusus yang lebih mahal atas jatah tambahan tersebut.

Tujuan diterapkannya kebijaksanaan pembedaan (diskriminasi) harga itu, antara lain adalah untuk menekan permintaan agen-agen. Sebab PT Jawa Pos ingin menekan angka kerugian dari sektor penjualan produknya. Apalagi saat itu perolehan iklan juga turun.

Namun diakui pihak manajemen bahwa kebijaksanaan diskriminasi harga itu menjadi bumerang. Kebijaksanaan itu malah merugikan perusahaan. Sebab agen-agen banyak yang lari ke perusahaan kompetitor. Artinya, agen yang membutuhkan tambahan koran akhimya minta ke perusahaan kompetitor PT Jawa Pos. Akibatnya, koran kompetitor oplahnya saat itu meningkat tajam, sementara oplah PT Jawa Pos menurun.

PT Jawa Pos lalu bangkit untuk merubah kekeliruannya itu. Caranya, agen-agen multimedia, yaitu agen yang tidak hanya menjual koran PT Jawa Pos namun juga menjual koran-koran lain, diawasi secara ketat. Agen-agen multimedia yang jatah koran dari kompetitomva lebih dari sepertiga jatah koran dari PT Jawa Pos, dikenai harga lebih mahal Rp 50 rupiah per eksemplar. Banyak agen yang mengurangi penjualan koran kompetitor Jawa Pos dan lebih memilih memperbanyak penjualan Jawa Pos. Sebab mereka menilai, penjualan koran ini masih lebih prospektif dibanding dengan penjualan koran kompetitor. Di sini PT Jawa Pos betul-betul memanfaatkan kekuatannya, terutama yang menyangkut brand name dan brand-image untuk melawan kompetitornya. Namun setelah Jawa Pos melakukan 
perubahan seperti itu, oplah koran kompetitor itu berangsur-angsur menurun hingga kini tinggal sekitar 60 ribu per hari.

e. Memacu Perolehan Iklan

Manajemen menyadari bahwa perolehan iklan sejak krisis ekonomi terus menurun. Karena itu, untuk tetap mempertahankan perolehan iklan selama krisis, manajemen melakukan terobosan apa yang disebutnya dengan partnering. Yaitu menggandengkan wartawan dengan bagian lain, terutama bagian iklan untuk bersama-sama mencari iklan.

Tujuan partnering ini, adalah lebih mendinamisasi bagian-bagian lain yang dianggapnya masih perlu ditingkatkan. Manajemen menyadari bahwa dengan berkurangnya jumlah dan lebar halaman koran maka bagaimanapun ruang untuk berita menjadi berkurang. Karena itu, agar wartawan tetap punya beban kerja yang cukup apalagi di saat krisis ekonomi maka ada beberapa wartawan yang diwajibkan ikut program partnering bekerja sama dengan bagian iklan untuk mencari iklan. Sebab pemasukan dari iklan merupakan salah satu sumber utama pendapatan perusahaan pers. Jika pemasukan dari iklan kecil apalagi tidak ada, maka perusahaan pers tidak akan bisa survive. Program partnering ini berlangsung selama krisis moneter mencapai puncaknya dan kemudian dihentikan setelah kondisi dianggap berangsur-angsur stabil.

Selain itu, manajemen juga melakukan efisiensi dalam femakaian space untuk iklan, khususnya iklan jitu. Sebab menurut perhitungan pihak manajemen, saat harga kertas koran mahal (tinggi), perolehan dari iklan jitu 
masih lebih rendah dibanding dengan pemakaian kertasnya. Karena itu, manajemen lalu membikin terobosan. Jenis dan ukuran huruf untuk teks iklan jitu diperkecil sementara nomor kode iklan yang biasanya dicantumkan di bagian bawah teks iklan jitu dihilangkan karena dianggap pemborosan tempat.

Selain itu, bagian tengah halaman yang sebelumnya ada ruang kosong, digunakan untuk satu kolom iklan jitu. Akibatnya iklan jitu menjadi lebih padat. Dengan kata lain, daya tampung halaman iklan jitu terhadap iklan menjadi lebih banyak. Artinya jika pada halaman berita setiap dua halaman hanya terdiri atas 14 kolom setiap halaman tujuh kolom namun khusus untuk dua halaman iklan jitu terdiri atas 15 kolom karena setiap halamannya bisa menampung 7,5 kolom.

\section{f. Memperbesar Diskon dan Periode Pembayaran}

Perubahan lain dalam hal harga, manajemen PT Jawa Pos selama 2001 memberikan diskon yang lebih besar kepada agen-agennya yang bisa membayar koran secara kontan. Tahun-tahun sebelumnya diskon seperti itu sebenarnya sudah diberikan namun selama 2001 makin ditingkatkan. Dari yang semula hanya 3 persen, lalu ditingkatkan menjadi 5 persen bagi agen yang mau membayar korannya secara kontan.

Pemberian diskon ini, dimaksudkan untuk merangsang agen-agen untuk mau segera membayar koran yang dibelinya. Juga sekaligus untuk mengimbangi bunga deposito di bank yang selama 2001 cukup tinggi. Pertimbangannya, jika tidak ada diskon untuk agen yang membayar kontan 
atau ada diskon namun rendah dikhawatirkan agen-agen akan lebih suka menahan uangnya untuk didepositokan terlebih dulu di bank dengan harapan mereka bisa mendapatkan bunga dari deposito yang saat itu cukup tinggi. Karena itu, dengan adanya rangsangan diskon 5 persen itu agenagen Jawa Pos diharapkan lebih suka membayarkan uangnya secara kontan daripada didepositokan dulu di bank selama satu atau dua bulan.

Dalam kaitannya dengan masa pembayaran (Payment period and credit term ), manajemen PT Jawa Pos juga melakukan perubahan. Sebelum krisis ekonomi 2001, masa piutang iklan perusahaan bisa sampai 90 hari namun akhirnya diperpendek menjadi tinggal 60 hari. Sedangkan piutang koran diagen-agen yang semula 45 hari diperpendek menjadi tinggal 25 hari. Artinya, sebelum 2001 pemasang iklan ataupun biro iklan diperbolehkan membayar biaya pemasangan iklannya 90 hari setelah iklannya termuat di koran. Begitu pula agen berhak membayar koran yang dibelinya selama 45 hari setelah pembelian.

Keberhasilan memperpendek piutang perusahaan itu, berkat kerja sama yang baik antara beberapa bagian melalui program partnering. Program ini dilakukan selama empat bulan dalam tahun 2001. Wujudnya bagian wartawan digandengkan dengan bagian iklan dan bagian keuangan untuk mencari iklan, termasuk melakukan penagihan piutang perusahaan. Dalam hal ini manajemen P.T Jawa Pos memanfaatkan keunggulannya di bidang SDM (Sumber Daya Manusia) yang cukup banyak. Apalagi, ketika koran terbit 16 halaman dengan ukuran tujuh kolom, maka ada sejumlah 
tenaga di bagian wartawan (redaksi) yang beban kerjanya berkurang. Karena itu dengan pertimbingan bahwa di saat krisis tenaga kerja harus lebih dioptimalkan, maka sejumlah wartawan ditugaskan juga mencari iklan bersama bagian iklan. Sebagian lainnya ditugaskan juga mencari iklan bersama bagian iklan. Sebagian lainnya ditugaskan melakukan penagihan piutang perusahaan bersama bagian keuangan.

g. Memperkuat Distribusi Lewat SCJJ

Di bidang layanan distribusi, manajemen PT. Jawa Pos melakukan berbagai perubahan. Tujuan utamanya adalah untuk meningkatkan kepuasan pelanggan, khususnya dalam hal kedatangan koran di tangan pembaca.

Langkah itu diwujudkan dengan satu tekad untuk lebih mempercepat kedatangan koran di tangan pembaca. Caranya dengan melakukan sistem cetak jarak jauh (SCJJ) di Solo dan Jakarta. Dengan menggunakan SCJJ ini maka pembaca di Solo dan sekitarnya maupun yang di DKI Jakarta dan sekitarnya bisa menerima koran dalam waktu yang hampir sama dengan pembaca di Surabaya dan sekitarnya.

Sebelum menggunakan SCJL pembaca di Solo dan sekitarnya menerima kiriman koran dari Surabaya. Begitu pula pembaca yang di DKI Jakarta dan sekitarnya. Akibatnya, karena pengiriman ke Solo melalui jalan darat (bukan pesawat) satu angkutan dengan koran untuk wilayah Madiun dan sekitarnya, maka jam kedatangan koran di Solo dan sekitarnya sering 
siang (terlambat). Naniun, dengan diterapkannya SCJJ di Solo, maku sebagian koran bisa dicetak di sana, lalu diedarkan untuk pembacanya di kota itu dan sekitarnya.

Dari total oplah Jawa Pos yang kini sekitar 310 ribu eksemplar sehari, 50 ribu eksemplar diantaranya dicetak di Solo. Sedangkan yang di Jakarta dicetak 25.000 eksemplar.

Koran yang dicetak di Solo untuk melayani pembaca di Solo, Kudus, Jepara, Cilacap, Yogyakarta, Semarang dan beberapa kota lainnya di Jateng. Sedangkan yang dicetak di Jakarta untuk melayani pembacanya di ibu kota negara itu dan Bali.

Sebelum ada SCJJ di Jakarta, pembaca di Bali dikirimi koran dari Surabaya satu mobil dengan koran untuk wilayah Banyuwangi dan sekitamya atau terkadang lewat pesawat dari Surabaya. Akibatnya, jam kedatangan koran Jawa Pos di Bali siang sekitar pukul 11.00. Dengan dilayani dari Jakarta lewat pesawat udara, jam kedatangan koran di Bali bisa lebih pagi. Selain itu, pengirimannya juga lebih terjamin kepastiannya.

Karena ada SCJJ di Solo dan Jakarta, maka manajemen menambah jumlah angkutan, baik yang untuk melayani Solo dan sekitamya, maupun yang untuk melayani Jakarta dan sekitamya serta Bali. Dengan cara seperti itu maka secara umum jam kedatangan koran Jawa Pos ditangan pembaca menjadi lebih awal (Pagi).

Bagi surat kabar, jam kedatangan ini sangat menentukan laku atau tidaknya produk itu. Apalagi untuk koran pagi. Koran yang bisa datang atau 
menemui pembacanya lebih awal dibanding pesaingnya, maka peluang untuk laku menjadi lebih besar. Sebaliknya, koran yang datangnya terlambat, atau lebih belakangan di banding pesaingnya, maka peluang untuk tidak terjual menjadi lebih besar. Dengan demikian, jika misalnya ada dua koran atau lebih yang kualitasnya kurang lebih sama, maka pembaca akan lebih memilih koran yang bisa datang lebih awal.

h. Memperbanyak Jaringan Distribusi

Selain dengan menerapkan SCJJ di Solo dan Jakarta, manajemen Jawa Pos selama 2001 juga memperbanyak agen atau penyalurnya. Ini dimaksudkan agar masyarakat yang hendak membeli Jawa Pos bisa kian lebih mudah mendapatkannya. Khusus untuk Surabaya, misalnya, agennya yang semula 120 buah ditingkatkan menjadi 130 buah untuk pelanggan. Sedangkan agen yang khusus melayani eceran dari semula 55 orang ditingkatkan menjadi 60 orang. Sementara agen di Jatim (di luar Surabaya) dari semula 475 agen menjadi 500 agen. Sedangkan agen di Jateng dari 140 menjadi 170. Jumlah agen di Jateng ini mengalami banyak penambahan karena Jawa Pos sedang ekspansi pasar di sana.

Pada tahun 2001, bagian pemasaran PT. Jawa Pos bermaksud memperkuat sistem distribusinya. Sebab diakui oleh manajemen perusahaan ini bahwa tampilan korannya yang kini hanya tujuh kolom, sehingga lebih sempit dua kolom dibanding koran kompetitomya, itu merupakan salah satu titik kelemahan koran ini. Sebab, dengan tampil lebih sempit maka akan ada 
anggapan bahwa koran ini koran mini. Selain itu, karena koran makin sempit maka ruang untuk berita menjadi berkurang. Padahal, umumnya pembaca yang membeli surat kabar, salah satu tujuannya adalah untuk bisa mendapatkan berita yang sebanyak-banyaknya dan sebaik-baiknya. Dengan koran kian sempit maka kapasitas atau daya tampung koran terhadap berita juga berkurang. Apalagi jika ruangnya banyak dihabiskan untuk iklan.

Melalui penambahan jaringan distribusi itu tampak sekali manajemen PT Jawa Pos ingin memanfaatkan sebaik-baiknya tentang keunggulannya atau kekuatannya untuk menghadapi krisis ekonomi 2001. Keunggulanny a berupa kecukupan modał, tenaga kerja, pengalaman dan kemampuan dalam penguasaan teknologi pencetakan koran, dimanfaatkan untuk melakukan SCJJ demi lebih mempercepat kedatangan koran di tangan pembaca. Begitu pula penguasaan jaringan distibusi dan kepemilikan power berupa brand name dan brand image, dimanfaatkan untuk lebih memperbanyak agen agar pelayanan kepada pelanggan bisa kian cepat dan mudah.

i. Membangun Image Koran Modern Melalui Promosi

Pada saat harga : kertas koran mahal dan fluktuatif, sementara perusahaan pers belum berani menyesuaikan harga jual produknya, perusahaan penerbitan pers hidup dalam kondisi yan j dilematis. Satu sisi mereka tidak ingin oplahnya menurun karena berarti market share-nya menjadi rendah yang dikhawatirkan akan berpengaruh pada minat pemasang iklan. Namun pada sisi yang lain perusahaan tidak ingin, atau 
tidak berani menaikkan oplah karena khawatir kerugian akibat penjualan koran kian besar.

PT. Jawa Pos juga mengalami kondisi seperti itu. Saat harga kertas koran mahal, perusahaan ini mengalami rugi besar akibat pemasukan dari hasil penjualan koran tidak sesuai dengan biaya produksi yang harus dikeluarkan. Namun untuk menaikkan harga jual koran juga tidak punya keberanian sebab kondisi ekstemal yang tidak memungkinkan. Misalnya karena menyadari daya beli masyarakat sedang mentirun, dan kompetitor juga tidak atau belum menaikkan harga.

Manajemen PT. Jawa Pos waktu itu sempat memilih membatasi atau bahkan mengurangi oplah. Sebelum itu, oplah koran ini sekitar 310 ribu eksemplar. Saat krisis kertas, manajemen sempat menginginkan hanya mencetak 200 ribu eksemplar. Yang berarti ada sekitar seratus ribu pelanggannya yang bakal tidak terlayani. Ini tujuannya untuk menghemat kertas, dan sekaligus mengurangi/memperkecil kerugian.

Cara yang dilakukan manajemen perusahaan ini adalah dengan membatasi jatah agen melalui diskriminasi harga. Namun temyata kebijaksanaan itu justru merugikan perusahaan, kemudian hal itu dicabut atau dihentikan.

Karena itu, manajemen Jawa Pos tetap berusaha mempertahankan image - nya di mata masyarakat. Caranya dengan melakukan promosi (advertising) melalui radio swasta dan media massa retak lainnya seperti majalah berita mingguan Tempo Jakarta. 
Iklan itu terutama untuk membangun image masyarakat terhadap koran. Jawa Pos berkaitan dengan mulai ditampilkannya koran wajah baru yang hanya tujuh kolom dengan sebutan Broadsheet Junior. Manajemen perlu keija keras agar produk barunya yang masih sangat asing di mata sebagian besar masyarakat pembaca koran di Indonesia, bisa diterima mereka. Bersamaan dengan diluncurkannya produk baru itu, yaitı. Februari 2001, manajemen melakukan riset pasar, minta tanggapan dan penilaian masyarakat tentang produk baru itu. Hasilnya sebagian besar menyatakan bisa menerimanya dengan alasan lebih praktis, lebih handy, dan lebih modern.

Demi membangun image bahwa koran wajah baru itu modern, manajemen memasang koran-koran ternama Amerika Serikat sebagai contoh atau sebagai model iklan. Dengan memasang koran-koran ternama Amerika Serikat yang berukuran tujuh kolom (broadsheet junior, wajah barı ${ }^{\star}$ Jawa Pos), bertahap pembaca punya image bahwa koran modern memang berukuran seperti itu (tujuh kolom), dan bukan lagi sembilan kolom. Akan berbeda seandainya yang dijadikan iklan koran tujuh kolom itu terbitan negara berkembang, maka image masyarakat acan berbeda. ini namanya membangun image masyarakat terhadap produk.

Berbagai langkah kreatif untuk melakukan perubahan pada setiap elemen bauran pemasaran PT Jawa Pos-terbukti efektif bagi kelangsungan hidup FT Jawa Pos. Berdasarkan laporan keuangan per 31 Desember 2001, yang sudah diaudit akuntan publik, terlihat efektifitas perusahaan s makin 
meningkat, nilai bersih dari total penjualan mencapai 240 milyar rupiah, pendapatan bersih meningkat menjadi 32,8 milyar rupiah, modal mengalami perkembangan yang signifikan menjadi 139,07 milyar rupiah.

Kalau kita komparasikan dengan laporan keuangan per 31 Desember 1999, tercatat nilai penjualan 133 milyar, pendapatan bersih 30 milyar, modal mengalami perkembangan signifikan sebesar 126 milyar rupiah. Karena itu, apa yang dicapai PT Jawa Pos Surabaya Selama krisis ekonomi sangat menakjubkan. Sebab, di tengah krisis ekonomi yang sangat berat, justrus manajemen $\mathrm{PT}$ Jawa Pos bisa meningkatkan pembacanya.

Dengan demikian nampak bahwa proposisi keempat mempunyai kesesuaian dengan kondisi empirik keputusan perubahan bauran pemasaran dalam PT Jawa Pos. Bahwa perubahan bauran pemasaran yang ditakukan secara tepat dengan melibatkan elemen-elemen bauran pemasaran akan mampu meningkatkan efektifitas organisasi. Hal itu ditunjang dengan kerja sama antar devisi atau departemen dalam PT Jawa Pos.

Berdasarkan ukuran efektifitas yang digunakan dalam peneitian ini, yaitu profitabilitas, volume penjualan dan perubahan modal. Membaiknya laporan keuangan mengindikasikan adanya kesesuaian atau terbuktinya indikator yang digunakan dalam penelitian ini, yang ditunjukkan dengan meningkatnya realitasi penjualan sebagaimana tertera dalam lampiran tentang realisasi penjualan.

Meningkatnya jumlah penjualan mengindikasikan jumlah pelanggan setelah dilakukan perubahan itu naik, berarti ukuran efektifitas yang 
digunakan menunjukkan indikasi positif. Naiknya jumlah pelanggan akar, berokorelasi positif dengan kenaikan jumlah laba yang diperoleh PT Jawa Pos. Besarnya laba yang diperoleh PT Jawa Pos akan sangat mempengaruhi efektifitas untuk ukuran perubahan modal. Dengan naiknya laba maka bagian laba yang disimpan perusahaan akan lebih besar sehingga struktur modal yang dimiliki $P \top$ Jawa Pos semakin kuat.

Efektifitas sistem yang telah dicapai PT Jawa Pos ini sudah sesuai dengan orientasi tujuan penelitian ini yaitu menilai sejauhmana pelaksanaan perubahan bauran pemasaran penerbitan Pers PT Jawa Pos dalam mengendalikan, memperbaiki serta meningkatkan efektifitas perusahaan. 


\section{BAB VI}

\section{PEMBAHASAN}




\section{BAB VI}

\section{PEMBAHASAN}

Bercasarkan evaluasi terhadap perubahan bauran pemasaran yang dilakukan PT Jawa Pos dapat dianalisis keunggulan dibandingkan sebelum perubahan maupun kelemahan-kelemahan yang mungkin masih dapat terjadi sebagai berikut :

\section{KEUNGGULAN}

a. Dengan promosi yang sangat gencar maka Jawa Pos sudah dikenal masyarakat secara luas. Terutama di Jatim, na na Jawa Pos bagi sebagian besar masyarakat sudah tidak asing lagi.

b. Image Jawa Pos di masyarakat juga cukup baik. Paling tidak ada kesan atau image bahwa Jawa Pos adalah koran kuning, koran yang hanya mencari sensasi atau koran yang tidak serius dan tidak dipercaya. Image masyarakat terhadap koran ini cukup bajgus. Koran ini merupakan salah satu koran yang terpercaya.

c. Dengan terbit sekitar 310.000 eksemplar setiap hari, Jawa Pos sudah termasuk produk massal. Ini diharapkan bisa efisien dalam biaya produksi, dan dengan demikian diharapkan bisa menjual dengan harga yang bersaing.

d. Orang-orang Jawa Pos termasuk profesional dan punya banyak pengalaman di bidang penerbitan surat kabar. Sebab koran ini terbit sejak 1 Juli 1949 dan sejak 1 April 1982 ditangani wartawan -wartawan senior dari Majalah Tempo yang sudah pengalaman. Pada generasi 
berikutnya, sebagian besar karyawannya lulusan sajana S-1 yang berkualitas baik.

e. Jawa Pos didukung teknologi yang cukup modern dan canggih. Kini memiliki lima unit mesin cetak dengan kapasitas masing-masing 50 ribu eksemplar per jam. Proses produksinya, mulaj dari penulisan berita sampai penataan lay out menggunakan komputer.

f. Jawa Pos cukup inovatif. Manajemennya berani mengubah produknya setiap saat dengan prinsip lebih baik dan disukai konsumen. Ini terlihat, koran ini berani tampil berwarna setiap hari, tampil 24 halaman dan sejak 9 Februari 2001 berani tampil dengan wajah barunya yang lebih kecil, broadsheet junior (tujuh kolom).

g. Manajemen Jawa Pos berorientasi pada kepuasan konsumen (customer satisfaction). Berbagai upaya atau inovasi produk dan layanannya diarahkan untuk memberikan kepuasan kepadi pelanggannya.

h. Jawa Pos punya pabrik kertas koran sendiri. Ini sangat menguntungkan karena dengan demikian soal pasokan kertas koran sebagai bahan baku utama koran, lebih terjamin. Begitu pula dengan memiliki percetakan sendiri, maka kekhawatiran akan tidak dicetak atau dicetak terlambat hampir tidak ada.

i. Jawa Pos punya jaringan yang sangat luas melalui JPNN (Jawa Pos News Network). Ini memungkinkan karena Koran ini memiliki puluhan anak perusahaan Koran yang terbesar di banyak pulau di negeri ini. Dengan demikian, jika Jawa Pos membutuhkan berita besar dari Irian 
Jaya, misalnya meski Koran ini tidak punya wartawan di sana, Koran ini bisa meminta bantuan ke wartawan Cenderawasih Pos, perusahaan Koran anggota PT Jawa Pos Group di Irian Jaya.

j. Jawa Pos punya akses yang cukup baik dengan kantor berita resmi baik dalam negeri maupun luar negeri. Dengan demikian, jika suatu ketika ada peristiwa besar di luar negeri dimana Jawa Pos tidak punya perwakilan atau wartawan di sana, koran ini bisa mendapatkan berita untuk pembacanya melalui kantor berita resmi luar negeri, misalnya Reuter (Inggris) yang memang punya jaringan sangat luas di hampir setiap negara di dunia ini.

k. Sebagai Koran yang sudah dikenal luas dan terpercaya, Jawa Pos mempunyai akses yarig cukup baik dengan nara sumber atau pakar untuk bisa wawancara secara eksklusif. Akses ini sangat diperlukan Jawa Pos untuk mendapatkan berita - berita yang berkualitas tentang suatu masalah.

1. Dengan kemammpuan manajemen PT Jawa Pos memberikan kompensasi kepada karyawannya dengan cukup baik maka perusahaan ini bisa mendapatkan karyawan yang berkualifikasi dan dengan etos kerja yang cukup baik. Selain itu tingkat turn over (keluar masuk) karyawan juga rendah.

m. Jawa Pos memiliki lembaga jaksa penuntut umum internal (ombudsmen) yang berfungsi untuk mengontrol dengan ketat terhadap karyawannya, 
terutama di bagian redaksi dan sekaligus bisa menjembatani antara Jawa Pos dengan masyarakat jika terjadi suatu persoalan.

\section{KELEMAHAN YANG DAPAT DIIDENTIFIKASI}

Meskipun perubahan bauran pemasaran dapat dinilai benar menurut landasan teori penelitian dan mempunyai keunggulan dibanding manajemen sebelumnya, namun masih terdapat kelemahan yang terdapat diuraikan sebagai berikut :

a. Sebagai dampak dari krisis ekonomi, pemasuká dari iklan selama 2001 juga menurun. Ini berpengaruh pada arus kas (cash flow) perusahaan dan juga pada pendapatan (income) dan keuntungan (profit) perusahaan.

b. Produk yang dihasilkan Jawa Pos merupakan produk yang gampang ditiru oleh pihak lain. Artinya, karena bisnis yang ditawarkan Jawa Pos adalah penjualan informasi kepada masyarakat, maka produk yang ditawarkan mudah ditiru perusahaan lain sejenis. Akibat, akan terjadi persaingan antar sesarna perusahaan sejenis.

c. Terialu banyak anak perusahaan. Kini ada 52 perusahaan yang dibawah naungan bendera Jawa pos. Sebagian terbesar diantaranya adalah perusahaan pers. Sebagian masih menumpang fasilitas Jawa Pos. Bahkan ada yang tidak hanya menumpang fasilitas, namun juga masih memerlukan subsidi. 
d. Dengan banyaknya anak perusahaan Koran dibawah naungan PT. Jawa Pos maka perusahaan ini menjadi tidak focus. Pada hal, untuk jangka panjang perusahaan yang fokus yang akan memiliki prospek yang lebih baik.

\section{PELUANG}

a. Di era reformasi dan keterbukaan ini, Koran bisa bebas menulis atau menurunkar, berita untuk pembacanya. Kondisi ini sangat berbeda di zaman Orde Baru dimana ada budaya telepon dari pejabat atau instanssi tertentu. Jika ada berita yang sekiranya dianggap menjelekkan pejabat, lalu ada telepon dari instansi tertentu agar koran tidak menurunkan berita tersebut. Namun kini, dengan adanya era reformasi dan keterbukaan seperti sekarang ini, ancaman pencabutan SIUPP (Surat Izin Usaha Penerbitan Pers) yang merupakan momok yang menakutkan bagi perusahaan pers, kini mulai menurun. Dengan demikian, perusahaan pers bisa lebih leluasa untuk memberitakan suatu peristiwa atau fakta di lapangan yang sesuai dengan kondisi yang sebenarnya.

b. Peluang membuat berita yang menarik lebih besar sehingga kemungkinan jumlah masyarakat yang tertarik untuk membeli koran juga membesar.

c. Menjelang akhir 2001 kondisi perekonomian sudah mulai stabil. Salah satu indikasinya bagi perusahaan pers adalah banyaknya perusahaan 
atau pengusaha yang beriklan di media massa. Banyaknya iklan yang terpasang di media massa ini merupakan satu peluang bagi perusahaan pers untuk meningkatkan pendapatannya.

d. Tingkat pendidikan masyarakat yang kian membaik membawa konsekuensi sendiri. Misalnya kebutuhan mereka terhadap informasi lewat bacaan juga meningkat. ini memberikan peluang kepada perusahaan pers untuk bisa memperluas pasé rnya.

\section{ANCAMAN}

a. Di era reformasi ini, pengurusan SIUPP dipermudah. Akibatnya, banyak pihak yang tertarik ingin mendirikan perusahaan koran. Sejak era reformasi yang antara lain ditandai dengan lengsernya Soeharto dari jabatan Presiden pada 21 Mei 1998, kini sudah ratusan SIUPP dikeluarkan oleh Departemen Penerangan. Ini sangat berbeda dengan era sebelumnya dimana prosedur mendapatkan SIUPP sangat sulit. Akhirnya, persaingan pers sangat terbatas. Namun kini kian banyak penerbitan pers sehingga tingkat persaingannya sangat ketat.

b. Masyarakat kini kian kritis. Kesalahan sedikit saja sering mengakibatkan kantor koran didatangi oleh pihak-pihak yang merasa dirugikan oleh suatu pemberitaan pers. Jawa Pos, misalnya beberapa kali kantornya didatangi puluhan massa yang merasa tokohnya atau lembaganya diberitakan oleh pers (Jawa Pos), yang mereka nilai 
kurang pas atau menjelekkan. Protes mereka ini bisa jadi sampai berlanjut ke pengadilan.

c. Secara makro diramalkan bahwa pertumbuhan ekonomi nasional masih minus, atau mungkin pertumbuhannya nol. Akibatnya, perekonomian masih dalam kondisi kurang menggairahkan. Ini juga berakibat pada kurang maraknya pemasangan iklan di media nıassa. Dalam kondisi seperti ini sebagian masyarakat daya belinya juga rendah. Akibatnya, minat dan kemampuan mereka untuk berlangganan koran atau membeli koran secara eceran juga rendah.

d. Harga kertas koran masih tinggi. Ini jika dibandingikan dengan harga kertas koran beberapa saat (hari) sebelum krisis ekonomi mulai Juli 1997. Akibat harga kertas koran yang merupakan bahan baku utama koran ini masih tinggi, maka harga jual produk penerbitan pers juga masih tinggi.

e. Perubahan selera masyarakat mungkin akan berubah dengan cepat seiring dengan perubahan situasi politik di neeeri ini. Ini juga berkaitan dengan era reformasi dan keterbukaan yang selera dicoba terus dituntut masyarakat dan tampaknya akan terus dikembangkan oleh penguasa. Perubahan selera ini juga terkait dengan makin meningkatnya taraf pendidikan masyarakat. Perubahan selera ini juga mengancam eksistensi Jawa Pos jika tidak segera diantisipasinya atau dibacanya sejak dini. 
f. Koran tanpa kertas (paperless news) dengan menggunakan teknologi internet. Banyaknya stasiun televisi (media elektrc nik audio visual) yang juga banyak merilis peristiwa-peristiwa aktual, bisa jadi menjadi ancaman bagi Koran konvensional (Koran dengan kertas).

\section{KELEBIHAN DAN KELEMAHAN}

Manajemen PT Jawa Pos Surabaya menilai bahwa masing-masing perubahan bauran pemasaran yang diterapkan selama 2001 mempunyai kelebihan dan kekurargan. Satu sama lain saling mendukung, saling menunjang, strategi yang satu bisa menutup kelemahan strategi yang lain.

Perubahan harga koran misalnya, dianggap sangat berperan dalam mengurangi kerugian dari penjualan koran saat harga kertas koran mahal dan ongkos cetak tinggi. Strategi menaikkan harga langganan sebesar Rp $5.000,00$ dari semula $\operatorname{Rp} 11.000,00$ menjadi $\operatorname{Rp} 25.000,00$ bisa memberikan tambahan penghasilan $\mathrm{Rp}$ 1,5 miliar per bulan (oplah dikalikan Rp 5.000,00 sebulan). Atau jika dihitung per hari, tambahan income itu adalah Rp 43,5 juta (Rp 145 dikalikan oplah per hari sekitar 300.000 eksemplar). Sebab manajemen menaikkan harga jual koran ke agen dari semula Rp 520 per eksemplar menjadi Rp 665 atau naik Rpi45 mulai I Juni2001.

Penetapan harga tinggi itu satu segi bisa mengurangi minat beli sebagian pelanggan. Namun satu segi lainnya bisa membangun image bahwa kualitas produk tetap terjaga. Begitu pula keputusan untuk melakukan pengurangan dan penyempitan halaman dari semula 24 
halaman menjadi tinggal 16 halaman, dan dari semula lebar sembilan kolom menjadi tujuh koloin. Dengan demikian ada efisiensi Rp 75 juti. per hari (Rp 250 dikalikan oplah sehari sekitar 300.000 eksemplar). Dari sisi ini, berarti pengurangan halaman itu cukup signifikan dalam kaitan dengan efisiensi di bidang biaya produksi. Dengan demikian bisa mengurangi beban kerugian yang harus ditanggung perusahaan saat itu.

Namun, seperti diakui oleh bagian pemasaran, penyempitan halaman itu juga merupakan sisi lemah dalam pemasaran. Oleh karena itu, untuk menutupi sisi lemah ini, bagian pemasaran gencar melakukan terobosan. Misalnya dengan memperkuat jaringan distribusi. Wujudnya dengan menambah jumlah agen, dan mempercepat jam tiba Koran melalui SCJJ (Sistem Cetak Jarak Jauh).

Keputusan untuk menekan oplah dengan cara melakukan diskriminasi harga bagi agen yang minta tambahan jatah koran, ternyata justru menjadi masalah bagi pemasaran. Penerapan harga progresif itu dikeluhkan oleh banyak agen. Sebab, saat keputusan itu diterapkan, permintaan akan koran sedang meningkat. Akibatnya, banyak agen yang berusaha untuk bisa tetap memenuhi permintaan konsumen (pelanggannya) dengan cara minta tambahan jatah ke perlisahaan koran pesaing Jawa Pos. Akibat berikutnya, demand terhadap koran kompetitor menjadi meningkat pesat, dan sebaliknya Jawa Pos justru membatasi dan menekan oplah. Akhirnya oplah koran kompetitor menjadi membesar, sementara Jawa Pos menjadi stagnan. 
Diskriminasi harga model itu kemudian dicabut, dan kemudian diterapkan dalam bentuk lain yaitu Jawa Pos tidak membatasi oplah, dan justru berusaha membatasi permintaan agen multimedia terhadap koran kompetitor. Caranya, bagi agen Jawa Pos yang juga menjual koran lain (kompetitor) ini yang disebut dengan agen multi media dikenai pera.uran baru yang ketat. Yaitu, bagi agen multimedia yang jatah koran kompetitor melebihi jatah koran Jawa Pos, mereka dikenai harga lebih mahal Rp 50 per eksemplar dibanding dengan agen lainnya.

Strategi diskriminasi harga model yang terakhir itu cukup membawa hasil. Sebab banyak agen multimedia yang akhirnya mengurangi jatah koran kompetitor dan sebaliknya memperbanyak jatah koran Jawa Pos. Sebab menurut perhitungan mereka, penjualan koran ini masih lebih prospektif dibanding dengan penjualan koran lain. 


\section{BAB VII}

\section{KESIMPULAN DAN REKOMENDASI}




\section{BAB VII}

\section{KESIMPULAN DAN REKOMENDASI}

A. Kesimpulan

1. Tekanan lingkungan organisasi yang mengakibatkan penurunan prestasi organisasi secara terus menerus mengharuskan PT Jawa Pos melakukan perubahan bauran pemasaran yang meliputi semua unsur dalam bauran pemasaran yaitu produk, harga, saluran distribusi dan promosi. Dengan melakukan perubahan tersebut PT Jawa Pos sedang berusaha meminimalisasi ketidakpastian usaha.

2. Proses perubahan bauran pemasaran pada PT Jawa Pos telah melibatkan unsur-unsur dominan dalam perusahaan sebagai agen dan pelaksana perubahan. Pelibatan unsur dominan dalam perusahaan sangat penting untuk bisa memberikan kemungkinan keberhasilan proses perubahan yang diperlukan untuk mempertahankan kelangsungan hidup perusahaan. Pelibatan unsur-unsur dalam PT Jawa Pos dilakukan melalui sosialisi yang intensif sehingga perubahan bauran pemasaran dapat terlaksana secara terencana, terarah sesuai dengan target yang ditetapkan.

3. Implementasi perubahan bauran pemasaran dilakukan dengan cara memperbanyak menggunakan forum resmi baik berupa rapat resmi perusahaan maupun forum-forum lain yang dibentuk untuk sosialisasi dan menampung berbagai pendapat dari karyawan manajemen maupun operasional. Di sini PT Jawa Pos lebih menempuh cara partisipatif dan 
persuatif. Pendekatan yang ditempuh PT Jawa Pos ini menjadikan proses perubahan bauran pemasaran menjadi berjalan sejalan dengan kondisi dan kultur karyawan PT Jawa Pos. Hal tersebut menjadikan tingkat konflik dapat dibatasi.

4. Proses perubahan bauran pemasaran PT Jawa Pos telah dilakukan secara tepat dengan melibatkan semua elemen-elemen bauran pemasaran, yaitu produk, harga, saluran distribusi dan promosi. Perubahan itu dilakukan dengan kerjasama yang sinergis antar departemen/divisi dalam perusahaan penerbitan pers. Dengan kerja sama yang sinergis antar departemen/divisi, efektifitas PT Jawa Pos bisa dicapai.

B. Rekomendasi

1. Pengalaman yang dimiliki Jawa Pos, dan berbagai kekuatan lain yang dimilikinya, hendaknya dimanfaatkan sebaik-baiknya untuk terus meningkatkan kualitas produknya. Ini mengingat tuntutan dan selera pembaca koran kian meningkat.

2. Tradisi manajemen PT Jawa Pos yang selalu inovatif, perlu terus dikembangkan. Sebab, salah satu kunci utama suatu produk bisa disukai konsumen adalah keberaniannya berinovasi ke arah yang lebih baik dengan tetap berorientasi pada kepuasan pelanggan. 
3. Terbukanya peluang membuat berita yang menarik di era refonnasi ini hendaknya dimanfaatkan dengan baik untuk lebih memuaskan pelanggan.

4. Banyaknya anak perusahaan, dimana yang sebagian masih "merepotkan" Jawa Pos, perlu segera dicarikan jalan keluarnya agar tidak kian membebani manajemen PT Jawa Pos, dan sekaligus koran ini bisa lebih tertokus.

5. Mengingat maraknya penerbitan baru di era reformasi ini, dan mungkin di masa-masa yang akan datang, pemasaran intelejen perlu ditingkatkan. Melalui pemasaran intelejen ini diharapkan manajemen banyak tahu tentang kiat dan strategi penisahaan pesaing, terutama dalam kaitannya dengan pemasaran.

6. Koran tanpa kertas melalui teknologi internet perlu diwaspadai. Sebab, meski pertumbuhannya relatif lamban di Indonesia antara lain karena faktor tingkat pendidikan, ekonomi, dan budaya namun lambat laun internet ini bisa berkembang dan ada kemungkinan akan bisa mengurangi pasar koran konvensional (koran dengan kertas). 


\section{DAFTAR PUSTAKA}

Gitosudarmo, Indriyo. 2000. Manajemen Pemasaran. Edisi Pertama. Yogyakarta: BPFE

Irawan. 1996. Prinsip-prinsip Pemasaran. Edisi Pertama. Cetakan Pertama. Yogyakarta: BPFE.

Kotler, Philip. 1987. Dasar- Dasar Pemasaran. Edisi Ketiga. Jakarta: Intermedia

Kotler, Philip. 1995. Manajemen Pemasaran. Jakarta: Salemba Empat

Kotler, Philip. 1996. Marketing Management: Analysis. Planning, Implementation. and Conirol, Ninth Edition. New Jersey: Prentice-Hall, Inc.

Kotler, Philip. 2002. Manajemen Pemasaran. Edisi Mileniurn. Jakarta: Prenhallindo

Payne, Andrian. 2001. Services Marketing Pemasaran Jasa. Yogyakarta: ANDI

Rangkuti, Freedy. 2001. Analisis SWOT Teknik Membelah Kasus Bisnis. Jakarta: Gramedia Pustaka Utama:

Robbins, Stephen P. 1994. Teori Organisasi, Struktur, Desain dan Aplikasi. Edisi Tiga, Terjemahan. Jakarta: Arcan.

Soedjatmiko, Basuki. 2001. Laporan Keuangan PT. Jawa Pos per 31 Desember 2001.

Yin, Robert K. 2002. Studi Kasus, Desain dan Metode. Terjemahan. Jakarta: Raja Grafindo Persada

Jawa Pos, edisi 6 Desember 1998

Tim Penulis Jawa Pos, Koran Kita, 1999. 


\section{LAMPIRAN}




\section{DAFTAR LAMPIRAN}

\section{Lampiran 1:}

Kerangka Penelitian EVALUASI "Peristiwa X" dengan Pendekatan Studi Kasus Yin.

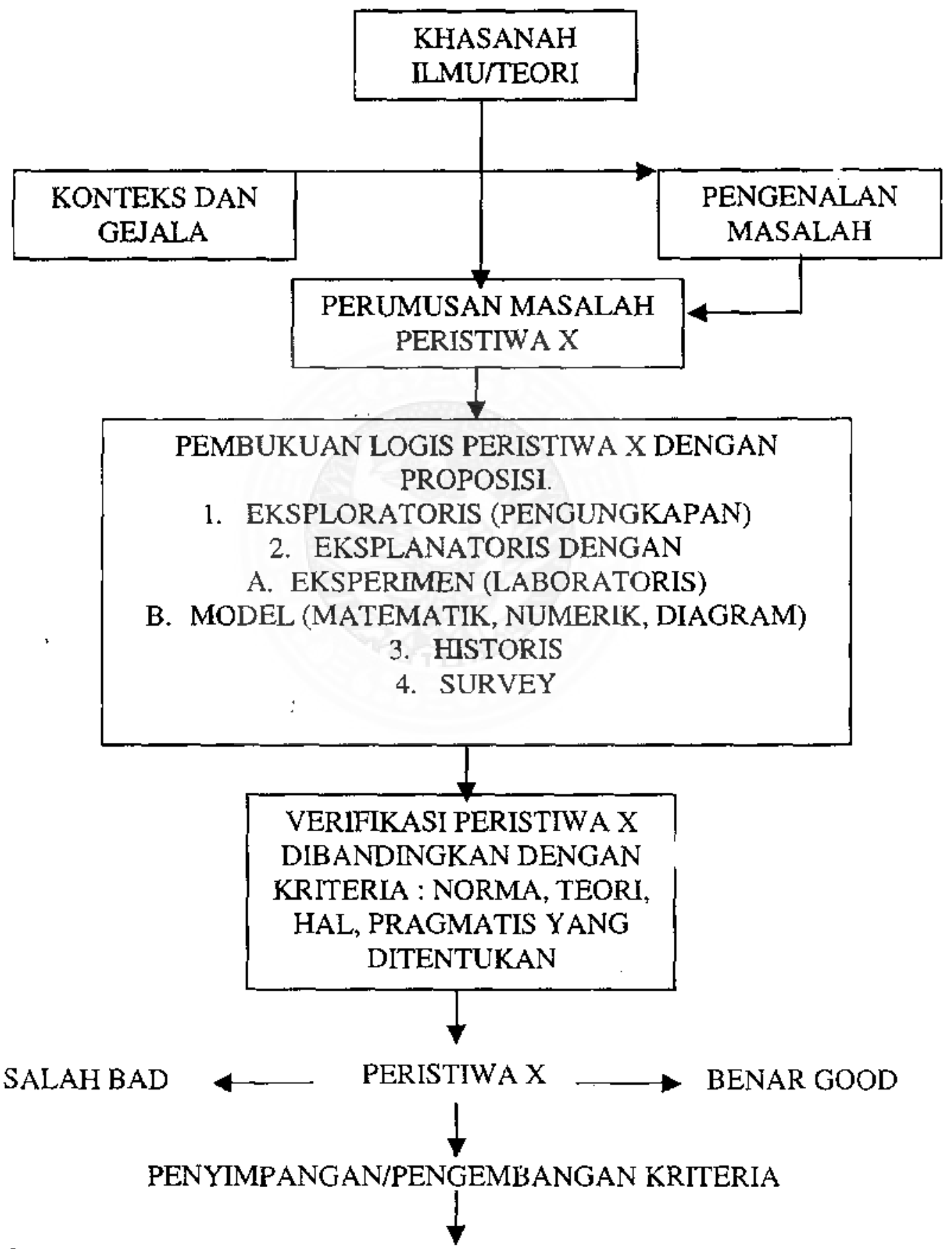

KEMUNGKINAN PENGEMBANGAN TEORI, MELALUI PENELITIAN REKOMENDASI 


\section{Lampiran 2 : Rangkuman Komparatif Peristiwa dalam Perusahaan dengan}

Proposisi Penelitian

\begin{tabular}{|c|c|c|c|}
\hline No & Proposisi & No & Peristiwa Empirik \\
\hline 1 & $\begin{array}{l}\text { Apabila tekanan lingkungan } \\
\text { organisasi mengakibatkan } \\
\text { penurunan prestasi } \\
\text { organisasi secara terus } \\
\text { menerus maka organisasi } \\
\text { akan melakukan perubahan } \\
\text { bauran pemasaran. }\end{array}$ & 1 & $\begin{array}{l}\text { Adanya tekanan lingkungan yang bersumber pada } \\
\text { krisis moneter t997. Menjadi tanya besar menghantui } \\
\text { Harian Jawa Pos ketika krisis moneter yarig begitu } \\
\text { dahsyat mulai menghantam Indonesia. Ketika itu } \\
\text { posisi bisnis Jawa Pos belum begitu mantap. } \\
\text { Kemampuan keuangannya masih terus digerogoti } \\
\text { oleh kewajiban - kewajiban yang timbul untuk } \\
\text { investasi membesarkan Jawa Pos itu sendiri di masa } \\
\text { lalu. Misalnya, untuk membeli mesin - mesin cetak } \\
\text { termodern yang tentu dengan cara leasing atau kredit. } \\
\text { Lebih dari itu Jawa Pos juga baru saja melahirkan } \\
\text { anak-anak perusahaan yang banyak sekali jumlahnya } \\
\text { dan luas sekali jangkauannya. Terlihat posisi Jawa } \\
\text { Pos memang sangat rawan terhadap badai knisis } \\
\text { yang begitu hebat. } \\
\text { Begitu banyak sisi. negatif yang bisa membuat } \\
\text { Jawa Pos rapuh di tengah badai tersebut. Disamping } \\
\text { itu perusahaan mempunyai kendala internal yang } \\
\text { cukup besar antara lain, melonjaknya harga bahan } \\
\text { baku seperti kertas, tinta dan biaya pemeliharaan } \\
\text { peralatan produksi. } \\
\text { Atas tekanan lingkungan dan kondisi internal } \\
\text { tersebut, perusahaan selama beberapa tahun } \\
\text { berturut-turut merugi dan tidak mampu membayar } \\
\text { kewajiban (pinjaman). Tekanan lingkungan dan } \\
\text { penurunan prestasi keuangan tersebut telah } \\
\text { diidentifikasi akan mengancam kelangsungan operasi } \\
\text { perusahaan. } \\
\text { Atas kondisi tersebut perusahaan kemudian } \\
\text { melakukan perubahan terhadap seluruh unsur bauran } \\
\text { pemasaran. }\end{array}$ \\
\hline 2 & $\begin{array}{l}\text { Agar perubahan bauran } \\
\text { pemasaran dapat terlaksana } \\
\text { secara terencana, terarah } \\
\text { dan sesuai dengan target }\end{array}$ & 2 & $\begin{array}{l}\text { Proses perubahan bauran pemasaran dalam } \\
\text { perusahaan, dimulai sejak adanya penjelasan khusus } \\
\text { dari CEO Jawa Pos Dahlan Iskan tentang bahaya- } \\
\text { bahaya dari krisis moneter yang terjadi saat itu. Dari }\end{array}$ \\
\hline
\end{tabular}




\begin{tabular}{|c|c|c|c|}
\hline & $\begin{array}{l}\text { yang ditetapkan, maka } \\
\text { diperlukan formalisasi } \\
\text { proses perubahan dengan } \\
\text { mengikut sertakan kekuatan } \\
\text { dominan organisasi sebagai } \\
\text { agen (penanggung jawab) } \\
\text { dan pelaksana perubahan. }\end{array}$ & & $\begin{array}{l}\text { penjelasan bahaya krisis ini kemudian CEO Dahlan } \\
\text { Iskan memberikan langkah-langkah perusahan yang } \\
\text { perlu diambil untuk menyelamatkan masa depan } \\
\text { bisnis Jawa Pos. } \\
\text { Penjelasan dari CEO itu kemudian diperinci dalam } \\
\text { bentuk menetapkan kebijakan pokok yang melibatkan } \\
\text { jajaran direktur utama, seluruh direksi dan manajer. } \\
\text { Di sini juga ditetakan pentingya melakukan evaluasi } \\
\text { pelaksanaan perubahan serta memberikan informasi } \\
\text { yang diaggap perlu. } \\
\text { Dengan demikian proses perubahan yang terjadi } \\
\text { di Jawa Pos melalui pembentukan agen seperti } \\
\text { tersusun dalam proposisi penelitian. Perubahan itu } \\
\text { langsung dimotori oleh CEO Jawa Pos Dahlan Iskan, } \\
\text { dengan memberikan pengarahan tentang langkah- } \\
\text { langkah yang perlu diambil untuk menyiasati krisis } \\
\text { moneter. } \\
\text { Namun demikian, proses perubahan itu telah } \\
\text { melibatkan unsur-unsur dominan dalam perusahaan, } \\
\text { yang bisa memberikan kemungkinan keterhasilan } \\
\text { proses perubahan yang diperlukan untuk } \\
\text { mempertahankankelangsungan hidup perusahaan. }\end{array}$ \\
\hline No & Proposisi & No & Peristiwa Empirik \\
\hline 3 & $\begin{array}{l}\text { Apabila proses perubahan } \\
\text { tidak disosialisasikan dan } \\
\text { diimplementasikan sesuai } \\
\text { dengan kultur dan tujuan } \\
\text { karyawan akan } \\
\text { memunculkan ketegangan } \\
\text { dan konflik. Oleh karenanya } \\
\text { diperlukan jalan tengah } \\
\text { untuk menyelesaikan } \\
\text { hambatan dan konflik } \\
\text { tersebut. }\end{array}$ & 3 & $\begin{array}{l}\text { Sejak ada penjelasan khusus dari CEO Jawa Pos } \\
\text { Dahlan Iskan tentang bahaya krisis moneter sejak } \\
\text { tahun 1997, mika proses pencairan status quo } \\
\text { (unfreezing) organisasi perusahaan dimulai. Tindak } \\
\text { lanjutnya kemudian dilakukkan berbagai perubahan } \\
\text { yang diperłukan untuk menyelematkan Jawa Pos dari } \\
\text { badai krisis moneter. } \\
\text { Dari sana kemudian pelaksanaan perubahan dimulai } \\
\text { (moving). . Hasil dari perubahan tersebut adalah } \\
\text { perubahan struktur organisasi, mempertegas } \\
\text { kewenangan (otonomi) departemen menjadi profit } \\
\text { centre, perubahan sistem kompensasi, proses } \\
\text { manajerial, dan pengukuran efektifit as perusahaan } \\
\text { serta perubahan susunan dan komposisi karyawan } \\
\text { (refreezing). } \\
\text { Sedang taktik Implementasi perubahan dilakukan } \\
\text { dengan cara memperbanyak menggunakan forum } \\
\text { resmi baik berupa rapat resmi perusahaan maupun }\end{array}$ \\
\hline
\end{tabular}




\begin{tabular}{|c|c|c|c|}
\hline & & & $\begin{array}{l}\text { forum-forum lain yang dibentuk untuk sosialisasi dan } \\
\text { menampung berbagai pendapat dari karyawan } \\
\text { manajemen maupun operasional. Dengan taktik } \\
\text { implementasi tersebut diatas, nampak bahwa } \\
\text { perusahaan menggunakan cara partisipatif dan } \\
\text { persuatif. Forum konsultatif juga dilakukan, dimana } \\
\text { forum ini merupakan forum untuk sosialisasi dan } \\
\text { mencari kompromi-kompromi, bisa mengakibatkan } \\
\text { perubahan target, dan jadwal perubahan. Cukup } \\
\text { banyak kompromi-kompromi dilakukan (khususnya } \\
\text { yang berkaitan dengan karyawan) sehingga tidak } \\
\text { banyak menimbulkan gejolak dan keresahan diantara } \\
\text { para karyawan. } \\
\text { Cara yang tempuh tersebut menjadikan proses } \\
\text { perubahan bauran pemasaran menjadi berjalan secara } \\
\text { perlahan karena banyak program perubahan bauran } \\
\text { pemasaran yang harus direvisi agar sesuai dengan } \\
\text { kondisi dan kultur yang berlangsung pada saat itu. } \\
\text { Namun hal tersebut menjadikan tingkat konflik dapat } \\
\text { dibatasi. }\end{array}$ \\
\hline No & Proposisi & No & Peristiwa Empirik \\
\hline 4 & $\begin{array}{l}\text { Apabila perubahan bauran } \\
\text { pemasaran dapat dilakukan } \\
\text { secara tepat dengan } \\
\text { melibatkan elemen-elemen } \\
\text { bauran pemasaran, maka } \\
\text { akan mampu meningkatkan } \\
\text { efektifitas organisasi. Oleh } \\
\text { karenanya, diperlukan } \\
\text { kerjasama yang sinergis } \\
\text { antar departemen/divisi } \\
\text { dalam perusahaan } \\
\text { penerbitan pers. }\end{array}$ & 4 & $\begin{array}{l}\text { Ada banyak langkah perubahan yang diten puh PT } \\
\text { Jawa Pos dalam kaitanya dengan bauran pemasaran. } \\
\text { Mengubah jumlah dan ukuran halaman koran Jawa } \\
\text { Pos. Meningkatkan kualitas berita. Meningkatkan nilai } \\
\text { voucher. Melakukan diskriminasi harga. Memacu } \\
\text { perolehan iklan. Memperbesar diskon dan periode } \\
\text { pembayaran. Memperkuat distribusi melalui Sistem } \\
\text { Cetak Jarak Jauh (SC,JJ). Memperbanyak jaringan } \\
\text { distribusi. Berbagai langkah kreatif untuk melakukan } \\
\text { perubahan pada setiap elemen bauran pemasaran } \\
\text { PT Jawa Pos terbukti efektif bagi kelangsungan hidup } \\
\text { PT Jawa Pos. Beraasarkan laporan keuangan per } 31 \\
\text { Desember } 2001, \text { yang sudah diaudit akuntan publik, } \\
\text { terlihat efektifitas perusahaan semakin meningkat, } \\
\text { nilai bersih dari total penjualan mencapai } 240 \text { milyar } \\
\text { rupiah, pendapatan bersih meningkat menjadi } 32,8 \\
\text { milyar rupiah, modal mengalami perkembangan yang } \\
\text { signifikan menjadi } 139,07 \text { milyar rupiah. } \\
\text { Kalau kita komparasikan dengan laporan } \\
\text { keuangan per } 31 \text { Desember 1999, tercatat nilai } \\
\text { penjualan } 133 \text { milyar, pendapatan bersih } 30 \text { milyar, }\end{array}$ \\
\hline
\end{tabular}




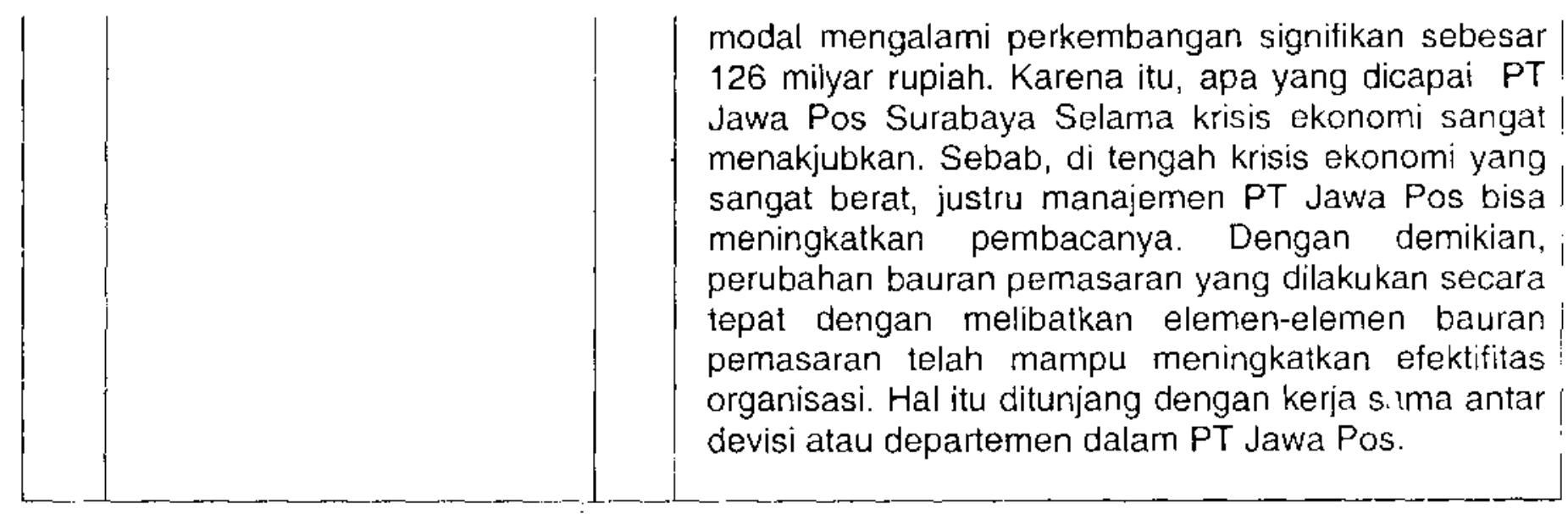

Lampiran 3 : Draf Pertanyaan Yang Diajukan

\begin{tabular}{|c|c|c|c|c|}
\hline No & Proposisi Penelitian & No & Daftar pertanyaan (open ended) & $\begin{array}{c}\text { Sumber } \\
\text { Bukti }\end{array}$ \\
\hline \multirow[t]{3}{*}{1} & $\begin{array}{l}\text { Apabila tekanan lingkungan } \\
\text { organisasi mengakibatkan } \\
\text { penurunan prestasi } \\
\text { organisasi secara terus } \\
\text { menerus maka organisasi } \\
\text { akan melakukan perubahan } \\
\text { bauran pemasaran. }\end{array}$ & $\overline{1}$ & $\begin{array}{l}\text { Apa saja faktor- aktor yang melatar } \\
\text { belakangi dilakukannya perubahan } \\
\text { dalam bauran pemasaran PT Jawa Pos, } \\
\text { baik secara internal seperti skala } \\
\text { ekonomi dan produksi, pembiayaan yang } \\
\text { lebih efisien serta faktor eksternal seperti } \\
\text { persaingan, perkembangan teknologi, } \\
\text { peluang pasar, kebijakan pemerintah dan } \\
\text { lain-lain. }\end{array}$ & $\begin{array}{l}\text { Dok., } \\
\text { Arsip, } \\
\text { Wawanc } \\
\text { ara }\end{array}$ \\
\hline & & 2 & $\begin{array}{l}\text { Apa saja yang dilakukan perusahac n } \\
\text { untuk merumuskan faktor-faktor yang } \\
\text { mempengaruhi perubahan bauran } \\
\text { pemasaran dalam perusahaan. }\end{array}$ & $\begin{array}{l}\text { Dok., } \\
\text { Arsip, } \\
\text { Wawanc } \\
\text { ara }\end{array}$ \\
\hline & & 3 & $\begin{array}{l}\text { Dapatkah saudara memberikan } \\
\text { gambaran mengenai rumusan perubahan } \\
\text { bauran pemasaran yanga akan dilakukan } \\
\text { perusahaan anda. }\end{array}$ & $\begin{array}{l}\text { Dok., } \\
\text { Arsip, } \\
\text { Wawanc } \\
\text { ara }\end{array}$ \\
\hline 2 & $\begin{array}{l}\text { Agar perubahan bauran } \\
\text { pemasaran dapat terlaksana } \\
\text { secara terencana, terarah } \\
\text { dan sesuai dengan target }\end{array}$ & 4 & $\begin{array}{l}\text { Apakah proses perubahan yang terjadi } \\
\text { dalam perusahaan didahului semacam } \\
\text { surat keputusan direksi atau direktur } \\
\text { utama, tentang pembentukan Tim untuk }\end{array}$ & $\begin{array}{l}\text { Dok., } \\
\text { Arsip, } \\
\text { Wawanc } \\
\text { ara }\end{array}$ \\
\hline
\end{tabular}




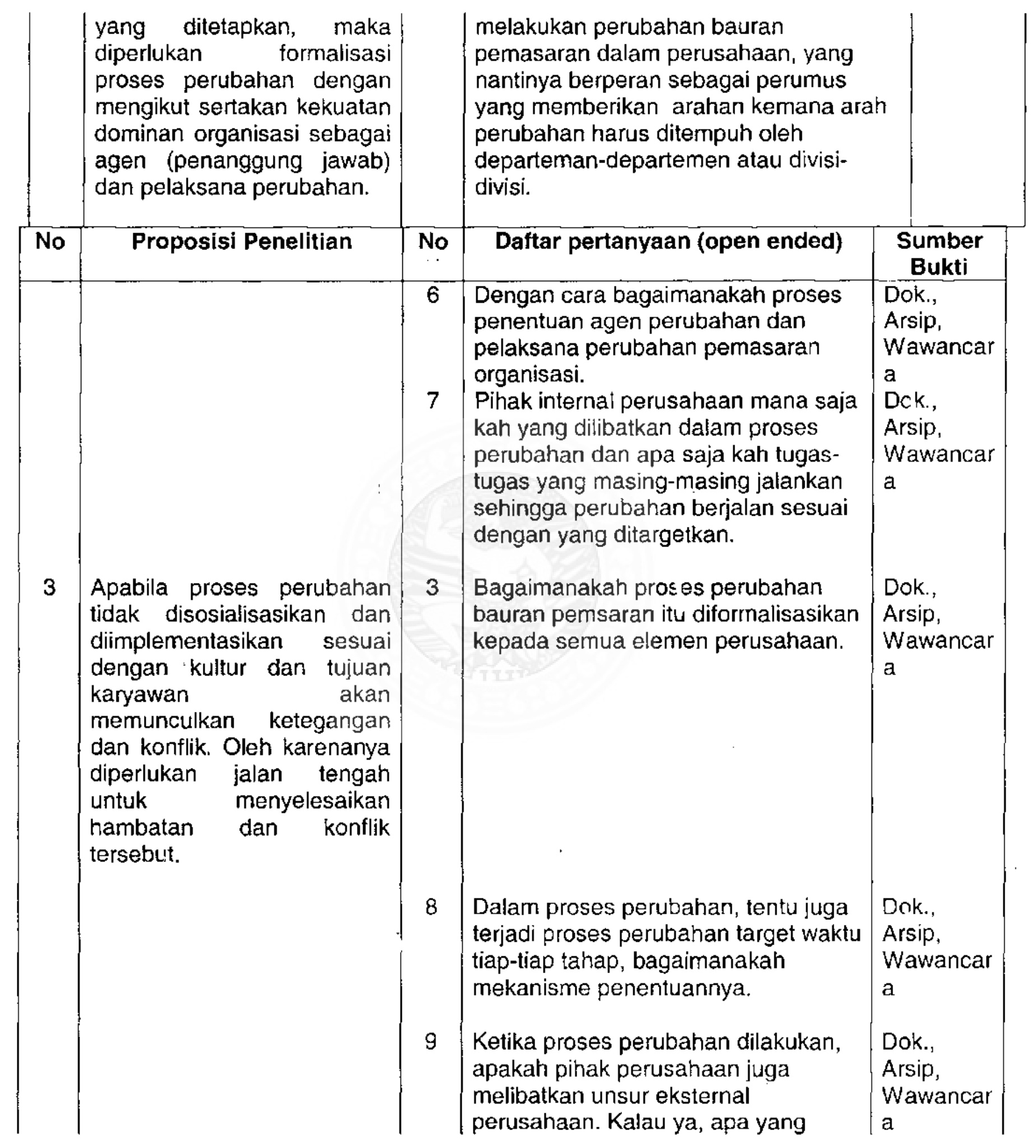




\begin{tabular}{|c|c|c|c|c|}
\hline & & 10 & $\begin{array}{l}\text { melatarbelakangi diperlukanya } \\
\text { keterlibatan unsur luar perusahaan. } \\
\text { Dalam hal hubungan antara } \\
\text { karyawan dengan agen perubahan, } \\
\text { apakah dalam relasi kedua unsur itu } \\
\text { juga menggunakan forum-forum, baik } \\
\text { resmi atau tidak, untuk mencari } \\
\text { kesepahaman substansi perubahan } \\
\text { yang akan dan sedang cilakukan } \\
\text { dalam perusahaan. }\end{array}$ & $\begin{array}{l}\text { Dok., } \\
\text { Arsip, } \\
\text { Wawancar } \\
\text { a }\end{array}$ \\
\hline No & Proposisi Penelitian & No & Daftar pertanyaan (open ended) & $\begin{array}{c}\text { Sumber } \\
\text { Bukti }\end{array}$ \\
\hline 4 & $\begin{array}{l}\text { Apabila perubahan bauran } \\
\text { pemasaran dapat dilakukan } \\
\text { secara tepat dengan } \\
\text { melibatkan elemen-elemen } \\
\text { bauran pemasaran, maka } \\
\text { akan mampu meningkatkan } \\
\text { efektifitas orgarisasi. Oleh } \\
\text { karenanya, diperlukan } \\
\text { kerjasama yang sinergis } \\
\text { antar departemen/divisi } \\
\text { dalam perusahaan } \\
\text { penerbitan pers. }\end{array}$ & 11 & $\begin{array}{l}\text { Dalam hai produk, saja yang } \\
\text { dilakukan perusahaan untuk } \\
\text { meningkatkan kualitas produk } \\
\text { Dalam hal harga, kebiijakan apa saja } \\
\text { yang dikeluarkan PT Jawa Pos agar } \\
\text { harga tetap bersaing dan bisa } \\
\text { memberikan keuntungan yang } \\
\text { maksimal bagi perusahaan. } \\
\text { Dalam hal distribusi, usaha-usaha } \\
\text { apa saja yang dilakukan PT Jawa } \\
\text { untuk memperkuat dan memperluas } \\
\text { jaringan distribusinya. } \\
\text { Dalam hal promosi, langkah-langkah } \\
\text { apa saja yang ditempuh PT Jawa Pos } \\
\text { dalam mempromosikan produknya. } \\
\text { Untuk melakukan perubahan } \\
\text { berbagai unsur bauran pemasaran, } \\
\text { sangat diperlukan kerjasama antar } \\
\text { departemen/devisi, bagiamanakah } \\
\text { proses kerjasama antara } \\
\text { departemen/divisi itu dilakukan di PT } \\
\text { Jawa Pos. }\end{array}$ & $\begin{array}{l}\text { Dok., } \\
\text { Arsip, } \\
\text { Wawancar } \\
\text { a } \\
\text { Dok., } \\
\text { Arsip, } \\
\text { Wawancar } \\
\text { a } \\
\text { Dok., } \\
\text { Arsip, } \\
\text { Wawancar } \\
\text { a }\end{array}$ \\
\hline
\end{tabular}




\title{
LAMPIRAN 4 \\ LAPORAN HASIL PENELITIAN DOKUMEN / ARSIP \\ DAN WAWANCARA
}

\author{
Pokok Penelitian : Faktor-faktor yang mendorong Perubahan Bauran Pemasaran \\ untuk Meningkatkan Efektifitas Organisasi. \\ Tanggal $\quad: 27$ September 2001 \\ Nara Sumber : Dahlan Iskan
}

Motivasi dasar dilaksanakannya perubahan bauran pemasaran tak bisa lepas dari fenomena krisis moneter tahun 1997. Krisis ekonomi .ang menimpa negeri ini sejak akhir tahun 1997, sangat berbeda sekali dengan krisis yang terjadi sebelumnya. Krisis kali ini lebih berat, lebih kompleks, biayanya (cost of crisis) lebih tinggi, dan dampak negatifnya sangat luas, termasuk telah memukul industri pers nasional akibat melonjaknya harga bahan baku seperti kertas, tinta dan biaya pemeliharaan peralatan produksi.

Pada saat yang sama, masyarakat hidup dalam dunia yang makin kompleks dan modern. Banyak kebutuhan yang harus dipenuhi dalam rangka memenuhi kebutuhan hidupnya, bahkan terus berkembang seirama dengan perkembangan yang ada di sekitarnya. Salah satu kebutuhan masyarakat yang semakin modern adalah kebutuhan informasi. Banyak sarana yang menawarkan suatu produk berupa informasi, yaitu melalui berbagai media. Berbagai media yang ada antara lain, media cetak dapat berupa surat kabar harian, majalah, jurnal dan sebagianya, dan media elektronik antara lain radio, telephone, faximile dan internet. 
Media yang menawarkan berbagai informasi ini mempunyai ciri khas yang berbeda-beda, masing-masing memiliki kebaikan dan juga memiliki kelemahankelemahan yang melekat pada produk yang dihasilkannya. Dalam rangka tersedianya informasi, seseorang tidak akan lepas dari usaha-usaha untuk melakukan keputusan pembelian, sebab secara umum sarana itu tidak dapat diperoleh secara gratis.

Salah satu produk yang dianggap paling penting untuk mendapat perhatian adalah surat kabar, sebab surat kabar ini memiliki keunikan tersendiri dan tidak terdapat di media lain, misalnya: kecepatan informasi, dapat disimpan, dapat dibaca sesuai dengan waktu yang diinginkan, dapat dibawa kemana saja dan sebagainya.

Terkait dengan situasi yang serba sulit akibat krisis ekonomi, maka kesuksesarı bisnis dalam industri pers sangat ditentukan sejauh mana perusahaan mampu melakukan perubahan sesuai dengan perubahan yang ada pada lingkungan perusahaan.

Perusahaan pers yang menerapkan prinsip-prinsip manajemen pers dan selalu responsif untuk melakukan perubahan sesuai perubahan lingkungan perusahaanlah yang akan jadi pemenang ditengah persaingan yang ketat. Karena bisnis penerbitan pers pada prinsipnya adalah perpaduan dari tiga kegiatan bisnis yaitu bidang redaksional, bidang percetakan, dan bidang unit usaha. Ketiga usaha ini dalam kegiatannya harus saling berkait dan mendukung satu sama lain. Penerapan manajemen pers mendapat tantangan serius di saat krisis moneter, terutama akibat harga bahan baku penerbitan pers naik dan cenderung berfluktuasi. Perusahaan pers 
diuji pada ketiga komponen utama pers tersebut bersinergi dan mengatur strategi menghadapi situasi yang sertia sulit.

Melonjaknya harga bahan baku media cetak (kertas, tinta, plate, film, dan lainlain) menyebabkan harga jual koran menjadi tinggi, dayc beli masyarakat menurun, akibatnya koran media cetak yang oplahnya kecil bisa langsung tutup. Akibat dikondisi diatas, perusahaan mengalami penurunan kinerja penjualan. Situasi sulit di atas, harus direspon penerbitan pers dengan mengambil langkah-langkah perubahan strategis.

Sasaran pokok dari perubahan dalam perusahaan itu adalah untuk menjadikan perusahaan sebagai badan usaha yang sehat sesuai dengan norma keuangan yang berlaku, mempunyai organisasi yang responsif terhadap perubahan, mampu bersaing di pasar, serta menjadi acuan masyarakat dalam mencari informasi. Sasaran jangka panjang perusahaan tetap menguasai pasar media cetak di Jatim, dan berusaha melakukan ekspansi ke daerah lain.

Sedang sasaran jangka pendek adalah menghasilkan produk yang berkualitas, biaya dan delivery yang bersaing pada pasar, organisasi dan manajemen yang dinamis, mantap dan efektif menghadapi perubahan, kemampuan personil yang tinggi, mampu melakukan penetrasi pasar dengan menggunakan keunggulan daya saing, dan mencapai penilaian wajar tanpa pengecualian dan sehat.

Perubahan dalam perusahaan yang dilakukan meliputi:

a. Bidang keuangan, yaitu merasionalkan aspek finansial neraca perusahaan, struktur modal, sistem pembiayaan, serta memperbaiki standar akuntansi dan prosedur. 
b. Bidang organisasi, manajemen dan sumber daya manusia, yang menyangkut aspek organisasi dan manajemen, sumber daya manusia.

c. Bidang usaha, yang menyangkut aspek peningkatan intensitas pemasaran, logistik, dan operasional.

Penyusunan program itu sendiri tidak diawali dengan pembentukan Tim khusus yang merancang program perubahan yang diperlukan dalam perusahaan. Akan tetapi, langsung dimotori oleh CEO Jawa Pos Dahlan Iskan yang menjelaskan segala sesuatunya kepada seluruh jajaran yang ada di dalam perusahaan.

Mula-mula dijelaskan bahaya krisis moneter yang akan memiliki dampak yang sangat serius terhadap kelangsungan dan masa depan perusahaan. Di sini CEO berusaha mati-matian untuk menyakinkan semua yang harus untuk mempercaya betapa besar bahaya krisis yang sedang menghadang.

Setelah itu dilanjutkan dengan penjelasan mengenai langkah-langkah strategis apa yang perlu dan harus diambil oleh perusahaan. Walaupun, tanpa pembentukan Tim khusus sebagai agen perubahan, akan tetapi dengan dimotori CEO Dahlan Iskan, hampir semua kekuatan-kekuatan dominan dalam perusahaan ikut terlibat langsung dalam proses perusahan yang sangat diperlukan untuk menyiasati bahaya krisis moneter saat itu.

Proses perubahan itu boleh dikatakan cukup lancar, terbukti dari waktu yang diperlukan untuk melakukan perubahan tidak terlalu lama. Selain itu, beberapa indikator kinerja perusahaan seperti penjualan juga mulai menunjukkan kecenderungan positif. Dengan demikian, tampak sekali program perubahan yang diperlukan dalam perusahaan telah berjalan lancar tanpa menemui hambatan yang berarti.

Surabaya, 5 Oktober 2001

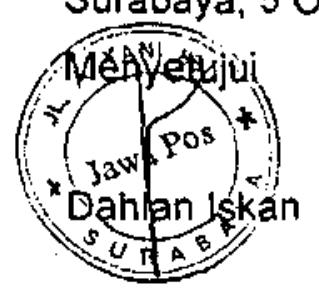


Pokok Penelitian : Perubahan penganggaran, pengukuran, pelaporan, penyusunan program, analisis perencaan strategis dan efektifitas organisasi.

Tanggal : 25 Oktober 2001

Nara Sumber : Jamin Hamid

Proses analisis perubahan pada Harian pagi Jawa Pos, dilakukan sejak krisis moneter terjadi, melalui berbagai forum pertemuan, baik formal maupu informal dengan dimotori langsung oleh CEO Dahlan Iskan. Dari hasil analisis terhadap kondisi perusahaan dan lingkungan eksternal, disusun program perubahan-perubahan yang akan dilaksanakan oleh masing-masing departemen. Program perubahan manajemen itu dimulai dengan adanya arahan program yang telah diberikan oleh CEO. Dalam perjalannya program perubahaan manajerial dalam Harian Pagi Jawa Pos sering mengalami perubahan sesuai dengan perkembangan kondisi perusahaan.

Perubahan kearah yang lebih pasti dimulai ketika ada keputusan tentang pemberian otonomi pada masing-masing departemen. Perubahan-perubahan dalam perusahaan itu tetap mengacu pada kinerja perusahaan, yang meliputi aspek pemasaran, produksi, teknologi, organisasi dan sistem manajemen sumber daya manusia, keuangan dan hasil usaha.

Dalam evaluasi tersebut dirumuskan permasalahan perusahaan sebagai berikut:

1. Faktor internal

a. Rentabilitas perusahaan sangat rendah, dan kemampuan perusahraan menyediakan pendanaan murah bagi pembeli masih lemah.

b. Jumlah wartawan di bagian redaksi terlalu banyak sehubungan dengan kebijakan pengurangan jumlah halaman. Wartawan yang kurang optimal fungsinya ini harus dijntensifkan kinerjannya dengan memindahkannya ke departemen iklan.

2. Faktor eksternal, yaitu : 
a. Tingkat persaingan pasar media massa yang semakin ketat. Hal ini sebagai akibat langsung dari maraknya terbit koran baru, baik lokal maupun nasional. Koran-koran baru ini harus dicermati perkembanganya karena punya potensi untuk merebut pasar Harian Pagi Jawa Pos.

b. Selain koran baru, koran-koran besar seperti Kompas juga mulai melakukan penetrasi di Jatim. Bahkan, kompas menamban halaman khusus yang berisi berita-berita khusus mengenai kondisi Jawa Timur. Sedikit banyak, perkembangan ini akan bisa menarik minat pembeli. Oteh karena itu, perkembangan semacam ini harus benar-benar dicermati dan diwaspadai oleh Jawa Pos.

c. Pengaruh inflasi dan nilai tukar vauta asing sangat besar, karena sebagian besar material dan peralatan masih impor.

Dengan berlandas tumju pada evaluasi tersebut, kemudian dirum uskan visi, misi, tujuan dan posisi yang diharapkan oleh perusahaan, sebagai berikut :

Visi perusahaan adalah sebagai industri penerbitan media massa yang berdaya saing tinggi.

Misi perusahaan adalah (a) terwujudnya industri media massa yang unggul yang mampu memenuhi kebutuhan seluruh lapisan masyarakat (b) memberikan kontribusi kepada pembangunan nasional, serta ikut mencerdaskan kehidupan bangsa melalui penyediaan berita yang kritis, aktual dan akurat.

Tujuan perusahaan adalah (a) melaksanakan usaha di bidang penerbitan media massa (b) menyediakan jasa percetakan untuk masyarakat umum yang ingin mencetak, buku, majalah, dan lain-lain. Untuk menjalankan strategi tersebut departemen periklanan dan pemasaran diperankan sebagai ujung tombak bisnis perusahaan.

Tahapan pencapaiannya adalah ditentukan sebagai berikut :

a. Survival, yang diharapkan selesai pada tahun 1997-2000 Dalam tahapan ini, yang akan dicapai adalah : 
1. Meningkatkan efisiensi dan produktivitas perusahaan sehingga perusahaan bisa memperbaiki kinerja keuangannya.

2. Melaksanakan penelitian dan pengembangan pasar ciengan memfokuskan pada produk unggulan/andalan dan segmen pasar yang menguntungkan.

3. Mendapatkan segera finansial support untuk mengatasi likuiditas perusahaan.

b. Diversifikasi dan pertumbuhan, yang diharapkaiı dapat dicapai pada tahun 2001-2003 adalah sebagai berikut :

1. Menciptakan usaha-usaha baru yang $n$ enguntungkan dengan ditunjang kompetensi yang dimiliki. Usaha ini diwujudkan dalam bentuk menerbitkan Radar daerah yang memiliki identitas dan sentimen daerah.

2. Mengembangkan usaha maupun kompetensi (teknologi) perusahaan sehingga bisa menghasilkan produk yang lebih berdaya saing.

Untuk mencapai tahapan tersebut disusun program perusahaan (corporate), antara lain :

a. Perspektif keuangan, yaitu (1) melaksanakan perencanaan dan pengendalian secara konsisten, (2) evaluasi dan menjual aktiva yang tidak produktif, (3) melaksanakan finansial engineering dan cash manajemen secara konsisten.

b. Perspektif customer, yaitu (1) memperbanyak jumlah agen, (2) meningkatkan kualitas produk.

c. Perspektif proses internal, yaitu (1) mengurangi birokrasi, (2) melaksanakan market studi, (3) melakukan aliansi dengan pihak luar dalam bidang pendanaan.

d. Perspektif pertumbuhan dan pembelajaran organisasi/sdm, yaitu (1) melaksanakan penyempurnaan pola diklat, (2) melaksanakan penerapan disiplin secara konsisten, (3) memodifikasi system pengendalian, (4) memperbanyak jumlah alat komunikasi dan mengefektifkan pemakaiannya. 
Dalam menjalankan tahapan dan program tersebut liatas, departemen/divisi diberikan wewenang sebagai pusat laba, namun tingkat kewenangan pemasarainya akan diberikan bertahap. Untuk setiap departemen berbeda dalam pertahapannya sesuai dengan kesiapan masing-masing departemen. Oleh karena itu masing-masing departemen menen tukan sendiri posisi lini/bidang usaha, yang meliputi :

a. Analisis industri

b. Analisis rantai nilai (Value change). Analisis ini disusun dalam bentuk matrix, dimana sisi vertical meliputi factor infrastruktur, teknologi, human resource, primary capability, sedang sisi horizontal meliputi factor sourcing, operation, marketing (sales and service).

c. Posisi usaha. Analisis ini disusun daiam bentuk matrix, dimana sisi vertical meliputi factor daya saing (kuat, setara, lemah), sedang sisi horizontal meliputi factor daya tarik usaha:

d. Strategi usaha

Dalam menyusun rencana jangka panjang perusahaan (RJPP) yang memuat strategi, program, target dan anggaran, secara prosedural tidak terdapat perbedaan yang mendasar.

Pada tahap awal penyusunannya, terdapat proses dialog dan tawar menawar antara corporate dengan departemen/divisi. Setelah ditetapkan, maka masing-masing departemen/divisi menjabarkannya sesuai dengan kewenangannya masing-masing. Pada level ini baru terdapat perbedaan proses dan pertanggung jawaban antara organisasi dan kewenangan yang lama, penyusunan tersebut seluruh departemen/divisi. Jadi pada level bisnis dalam penjabarannya terdapat proses yang lebih sederhana dan singkat sesuai dengan kebutuhan masing-masing departemen/ divisi.

Perbedaan lain adalah pada penentuan keefektifan organisasi. Ukuran keefektifan organisasi selain terdapat pada level corporate, terdapat pula ukuran 
keefektifan pada level departemen/divisi, yang ha! ini pada organisasi yang lama tidak ada. Untuk masing-masing departemen/divisi mempunyai ukuran keefektifan yang beda, sesuai dengan kondisi dan spesifikasi kerjanya. Ukuran keefektifan organisasi tersebut merupakan kesepakatan bersama antara corporate dengan pihak departemen/divisi.

Selain itu, ukuran keefektifan organisasi juga lebih dirinci, dipertajam dan terdapat progres berdasarkan periode waktu, dan harus dapat diukur. Ukuran yang bersifat kualititatif diukur berdasarkan waktu dan pencapaian, sedang ukuran kuantitatif diukur berdasarkan rupiah atau dollar, jumlah satuan, ratio dan prosentase.

Surabaya, 12 Nopember 2001

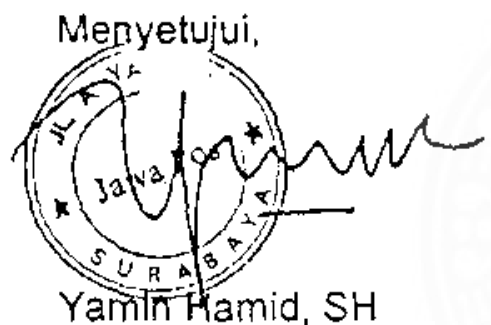


Pokok Penelitian : Struktur Organisasi PT Jawa Pos

Tanggal : 27 Nopember 2001

Nara Sumber : Yamin Hamid, $\mathrm{SH}$

Adapun struktur organisasi Harian Pagi Jawa Pos di Surabaya yang menjelaskan bagian-bagian dalam suatu organisasi dan kewenangannya adalah sebagai berikut:

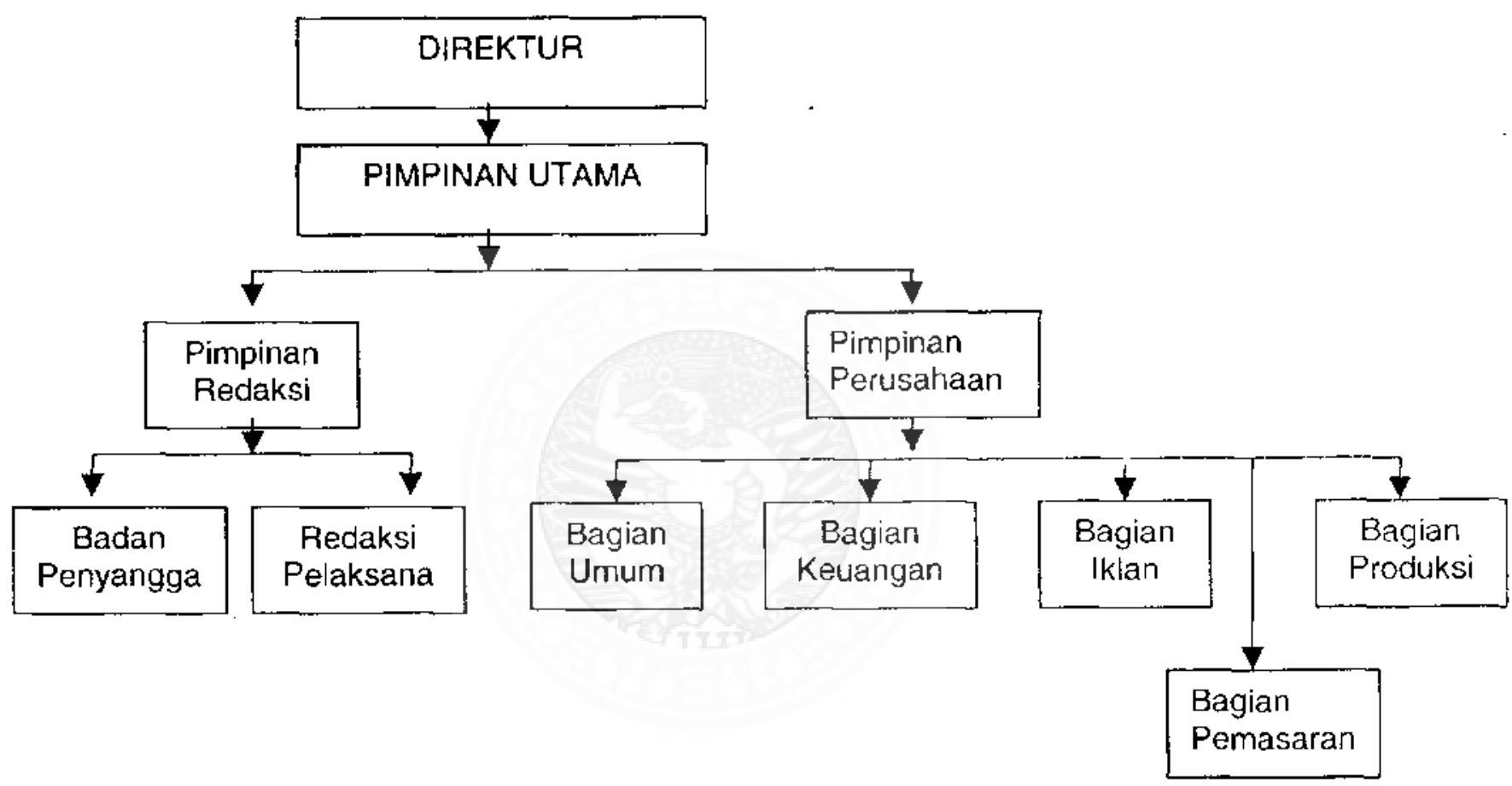

Adapun pembagian kerja pada perusahaan penerbitan media massa PT Jawa Pos di Surabaya ini adalah;

1. Direktur Utama

- Sebagai pemimpin dan penaggung Jawab tertinggi perusahaan. 
- Menentukan kebijakan pokok perusahan baik intern maupun ekstern di bidang perencanaan, penyusunan, pengarahan, pengunaan, pengembangan, pengaman dan pengendalian faktor-faktor produksi perusahaan.

- Melakukan dan membina kegiatan dan hubungan dengan pihak-pihak di luar perusahaan.

- Atas nama perusahaan mengadakan dan menandatangani segala perjanjian dengan pihak luar perusahaan dalam usaha pengembangan perusahaan dalam batas-batas tertentu.

- Memberi pertanggungjawaban atas hasil-has il usaha berskala dari kegiatan-kegiatan perusahaan kepada pemegang saham.

2. Pemimpin Umum

- Memimpin dan tertanggung jawab terhadap kegiatan perusahaan sehari-hari.

- Mengkoordinasi dan mengawasi pelaksanaan kebijakan perusahaan baik intern maupun ekstern.

- Melaksanakan pengawasan atas kelancaran jalannya perusahaan secara keseluruhan.

- Pemimpin umum memberikan wewenang otomatis kepada wakilnya bila berhalangan.

\section{Pemimpin Redaksi}

- Bertanggung jawab atas terlaksananya jurnalistik.

- Mengkoordinasi para direktur, sekretariat dan lembaga-lembaga di bawahnya.

- Mendelegasikan sebagian dari wewenang dan tanggung jawab kepada para direktur pelaksana sesuai dengan bidangnnya masing-masing.

- Mengarahkan isi surat kabar setiap kali terbit. 
- Bekerja sama dengan pemimpin perusahaan dalam mengkoordinasi kegiatan persiapan sampai dengan pelaksanaan pembuatan surat kabar.

\section{Pemimpin Perusahaan}

- Memimpin dan bertanggung jawab atas pelaksanaan tugas dari bagian umum, keuangan, pemasaran, iklan, produksi dan bagian pengawasan.

- Mendelegasikan sebagian dari wewenang dan tanggung jawab kepada para kepala bagian sesuai dengan kerjanya masing-masing.

- Mengkoordinasi keçiatan bagian-bagian yang dibawahnya açar dapat bekerjasama secara serasi.

- Bekerjasama dengarı pimpimpin umum dan bagian redaksi.

5. Bagian Umum

- Bertanggung jawab atas bagian kepegawaian di dalam perusahaan.

- Mengatur masalah logistik perusahaan serta rumah tangga kantor.

- Membantu menyusun anggaran kepegawaian, logistik dan rumah tangga kantor serta keperluan logistik transportasi.

- Bertanggung jawab atas pengaturan pemakaian dan pemeliharaan kendaraan perusahaan.

- Memimpin, mengawasi dan bertanggung jawab atas pelaksanaan bagian-bagian yang dibawahnya, yaitu: sub bagian kepegawaian, sub bagian logistik dan rumah tangga kantor dan sub bagian kendaraan.

6. Kepala Bagian Keuangan

- Bertanggung jawab atas pelaksana penyusunan rencana-rencana perusahaan.

- Melaksanakan pengawasan atas jalannya keluar masuk keuangan perusahaan. 
- Mengkoordinasi dan mengawasi pelaksanaan kebijaksana an perusahaan yang berkaitan dengan keuangan perusahaan baik intern maupun ekstern.

- Mendelegasikan sebagian wewenang dan tanggung jawab kepada wakil direktur keuangan dan wakil direktur umum/administrasi/personalia.

- Menyusun pertanggungjawaban keuangan secara periodik dan tahunan.

- Memimpin, mengawasi dan bertanggung jawab atas pelaksanaan bagian-bagian yang dibawahnya yaitu sub bagian kasir, sub bagian inkaso dan sub bagian pembukuan.

7. Kepala Bagian Pemasaran

- Menyelenggarakan penjualan koran Jawa Pos

- Menyelenggarakan pengiriman koran Jawa Pos dari percetakan kepada penyalur dan agen.

- Mencari pelanggan baru dengan memantau keinginan para konsumen surat kabar

- Pelaksana pelaporan, percetakan dan penelitian pasar.

- Pelaksana surat kabar dari pelanggan.

- Memimpin, mengawasi dan bertanggurig jawab atas pelaksanaan bagian-bagian yang di bawahnya, yaitu: sub bagian ekspedisi, sub bagian pelanggan dan sub bagian tata usaha.

8. Kepala Bagian Iklan

- Menerima pesanan pemasangan iklan di koran Jawa Pos.

- Mempelajari dan berupaya mencari ide bagi lay out yang menarik dibaca para konsumen Jawa Pos.

- Pelaksanaan penagihan kepada para agen dan penyalur. 
- Memimpin, mengawasi, dan bertanggung jawab atas pelaksanaan bagian yang dibawahi, yaitu: sub bagian order design dan sub bagian sales penagihan.

9. Kepala Bagian Produksi

- Menyusun rencana produksi.

- Mengendalikan pelaksanaan rencana produksi sesuai dengan yang telah digariskan.

- Pembinaan karyawan bagian percetakan.

- Penyelenggara administrasi produksi sesuai yang telah ditetapkan.

- Pengawasan terhadap efisiensi dan efektifitas pelaksanaan proses produksi.

Dengan demikian struktur organisasi ini secara teoritik merupakan struktur organisasi fungsional yang bersifat sentralistik. Semua ini langsung dibawah direktur utama yang sehari-hari dilaksanakan oleh koordinator kegiatan dimana seluruh kewenangan kewenangan dan keputusan terletak pada direktur utama.

Namun demikian, dalam prakteknya struktur organisasi itu tidak bersifat terlalu kaku, karena dalam berbagai forum pun jajaran direktur juga sering miminta pertimbangan dari SDM atau departemen yang ada di bawah manajemennya. Apalagi, setelah ada perubahan justru departemen iklan di beri otonomi dan dijadikan sebagai pusat laba.

Surabaya, 12 Nopember 2001

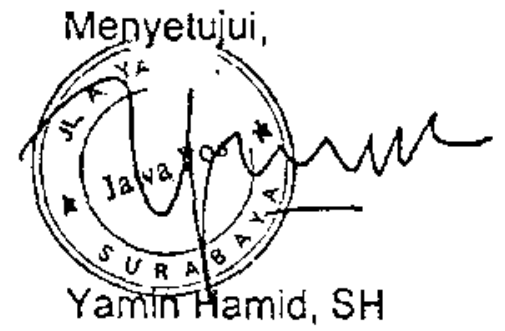


Pokok Penelitian : Reward System, Penataan karyawan

Cara Implementasi

Tanggal $\quad: 5$ September 2001

Nara Sumber : Drs. Nadim Zuhdi, MSi

Penataan Ulang karyawan diposisikan sebagai konsekuensi untuk meningkatkan performenance perusahaan dengan indikator kemampuan menyediakan produk yang lebih berikualitas sesuai dengan tuntutan perubahan dan penerapan strategi bisnis perusahaan.

Penataan ulang pegawai inı disebabkan cukup banyak tenaga kerja yang Restrukturisasi ini terjadi disebabkan cukup banyak tenaga kerja (wartawan) yang hanya memiliki jam kerja kurang maksimal karena adanya pengurangan halaman surat kabat. Dengan demikian nampak sekali mereka kurang maksima! dalam jam kerjanya.

Oleh karena itu tujuan dari penataan ulang ini adalah untuk lebih mengoptimalkan jam kerja karyawan, meningkatkan utilitas tenaga kerja/SDM melalui keseimbangan antara kuantitas dan kualitas/profesionalisme, serta sikap dan budaya wira usaha yang positif. Strategi yang dilakukan perusahaan untuk merealisasikannya adalah menata ulang struktur SDM, mengevaluasi dan menyempurnakan sistem rekrutmen dan penilaian personil, dan pengenalan falsafah budaya perusahaan serta sikap kerja baru. Sedang program kerja untuk mengimplementasikan penataan ulang tersebut anatara lain:

1. Akan dilakukan perubahan komposisi tenaga kerja yaitu para wartawan yang kurang optimal utiliasnya di BKO kan ke departemen iklan. Proses ini juga mempertimbangkan faktor usia, evaluasi kinerja, dan latar belakang kompetensi. 
2. Menanamkan budaya perusahaan sesuai dengan strategi bisnis aliansi, yaitu melalui perumusan buda ‘a formal, sosialisasi budaya perusahaan, pelatihan sikap kerja yang positif, pelatihan leadership, perbaikan sistem manajemen SDM yang meliputi sisterr. rekruitmen, performance apraisal, reawrd system, career system, pola training. Dalam kaitan pengembangan budaya perusahaan, telah banyak forum-forum yang diselenggarakan untuk karyawan dalam rangka sosialisasi budaya perusahaan dan pengembangan wawasan tentang sikap kerja, kepemimpanan dan lain-lain.

3. Dalam proses penataan ulang, akan dihindari terjadi PHK karyawan. Cara yang ditempuh, selain memindahkan wartawan Jawa Pos ke bagian iklan, juga dilakukan dengan cara memindahkan wartawan itu ke anak perusahaan Jawa Pos, yaitu Suara Indonesia. Hal ini penting dilakukan agar tidak timbul gejolak dalam perusahaan. Selain itu, untuk menghindari PHK, beberapa karyawan senior diserahi unit usaha sendiri untuk keloia secara mandiri.

Sebagai konsekuensi dari perubahan pola kompensasi, perusahaan akan menyusun model catatan dan penilaian prestasi kerja dalam bentuk daftar prestasi kerja. Dengan adanya model penilaian prestasi kerja tersebut, dipakai sebagai acuan untuk menilai prestasi keija karyawan dan perusahaan. Bagi karyawan penilaian prestasi tersebut merupakan evaluasi terhadap perkembangan kompetensi, penentuan pengiriman untuk diklat dan sekolah serta mutasi dan promosi dalam jabatan.

Penilaian prestasi kerja tersebut akan dikaitkan langsung dengan keefektifan organisasi yang telah dirumuskan oleh perusahaan yang dituangkan secara formal pada rencana jangka panjang perusahaan.

Surabaya, 17 Oktober 2001

Menyetujui,

Nadim Zuhdi, MSi 
Pokok Penelitian : Perubahan Unsur-Unsur Bauran Pemasaran PT Jawa Pos Tanggal $\quad: 7$ Nopember 2001

Nara Sumber : Abdul Aziz.

Untuk perubahan unsur-unsur Bauran Pemasaran PT Jawa Pos, meliputi semua unsur bauran pemasaran yaitu produk, harga, distribusi dan promosi. Langkah konkret yang diambil PT Jawa dalam kaitannya dengan perubahan bauran pemasaran adalah sebagai berikut:

\section{a. Mengubah Jumtah dan Ukuran Halaman}

Untuk menghadapi krisis ekonomi 2001, manajemen PT. Jawa Pos menerapkan beberapa kebijaksanaan yang berkaitan dengan produknya. Antara lain mengubah ukuran koran dan mengurangi jumlah halaman. Ukuran koran yang semula terdiri atas sembilan kolom setiap halaman, dipersempit menjadi tinggal tujuh kolom. Sedangkan jumlah halaman koran yang semula 24 halaman setiap hari dikurangi menjadi tinggal 20 halaman. dan bahkan akhimya tinggal 16 halaman.

Pengurangan dan penyempitan halaman ini dilakukan dengan pertimbangan bahwa harga kertas koran selama 2001 tidak stabil, mengalami kenaikan beberapa kali seiring dengan fluktuasi nilai tukar dolar Amerika Serikat terhadap rupiah. Dengan pengurangan dan penyempitan halaman, perusahaan ini bisa melakukan efisiensi penggunaan kertas. Dengan demikian ada efisiensi dalam bidang produksi.

Pertimbangan lain mengapa efisiensi penggunaan kertas itu dilakukan karena manajemen menganggap tidak mungkin menaikkan hargajual koran saat itu, meski harga bahan baku produksinya naik tajam. Manajemen memandang sangat tidak realistis jika kenaikan harga kertas itu dibebankan secara langsung kepada pelanggan dengan cara menaikkan hargajual koran yang ekuivalen dengan kenaikan harga kertas koran. Sebab saat itu masyarakat sedang dilanda krisis ekonomi. Dan lagi, perusahaan pers yang lain, termasuk juga surat kabar pesaing, saat itu tidak menaikkan harga produknya.

Saat harga kertas naik tajam seiring dengan naiknya kurs dollar terhadap rupiah, PT. Jawa Pos sempat mengalami kerugian besar dari hasil penjualan produknya (koran). Sebab biaya produksi naik, sementara 
perusahaan tidak segera bisa menaikkan harga jual produknya karena pertimbangan seperti disebut di atas.

Pada periode 1 Januari 2001 hingga akhir Mei 2001, misalnya harga langganan koran Jawa Pos adalah R-p 50.000 per bulan. Hargajual dari penerbit (perusahaan) ke agen adalah Rp 820 per eksemplar. Padahal, ongkos cetak atau biaya produksinya di atas hargajual ke agen itu.

Sebagai contoh, pada 1 Januari 2001, ongkos cetak adalah Rp 868 per eksemplar. Pada 8 Januari 2001, ongkos cetak itu naik menjadi Rp 1.028 per eksemplar, pada 20 Januari naik menjadi Rp 4.005 per eksemplar, dan pada 22 Januari turun menjadi Rp 1.040 per eksemplar.

Naik turunnya ongkos cetak (terutama biaya kertas, tinta dan percetakan) itu karena kurs dolar yang saat itu sangat tidak stabil. Pada 9 Februari 2001 ongkos cetak adalah Rp 411,2 per eksemplar. Itu artinya masih di atas hargajual koran.

Pada 6 Maret 2001, misalnya ongkos cetak mencapai Rp 995 per eksemplar. Pada 19 Maret turun menjadi Rp 827, pada 26 Maret 742, pada 30 Maret Rp 740 dan dalam April 2001 ongkos cetak berkisar pada angka Rp 707 per eksemplar. Saat ongkos cetak mencapai di atas Rp 800 per eksemplar, perusahaan Jawa $P 0^{\wedge}$ mengatami kerugian dari penjuaian korannva. Sebab, ongkos cetaknva leblh mahal dari pada hargajual korannya. Baru ketika ongkos cetak di bawah Rp 800 per eksemplar, perusahaan mendapatkan laba dari hasil penjualan koran. Karena ixu, pengurangan dan penyempitan halaman itu dimaksudkan untuk mengurangi pemakaian kertas. Dengan demikian perusahaan bisa menekan ongkos produksinya.

b. Meningkatkan Kualitas Berita

Strategi lain yang menyangkut produk ialah bahwa manajemen Jawa Pos bekerja keras untuk meningkatkan kualitas berita-berita yang disuguhkan kepada pelanggannya. Manajemen menyadari bahwa dengan pengurangan dan penyempitan haiaman maka porsi berita yang disuguhkan kepada pelanggannya juga berkurang. Apalagi jika ruang/halaman yang sudah berkurang itu juga digunakan untuk iklan.

Menyadari kondisi seperti itu, manajemen perusahaan berjuang keras untuk meningkatkan kualitas berita. Caranya, di bagian redaksi kian selektif terhadap berita-berita yang akan dimuat atau diturunkan. Dengan 
cara ini manajemen berharap pembaca tetap terpuaskan oleh sajian beritanya.

Untuk meningkatkan kualitas berita tersebut, manajemen melakukan berbagai langkah. Diantaranya melakukan penyegaran terhadap bagian redaksi. Bagian redaksi, mulai dari reporter hingga redaktur diberi pengarahan. Intinya diingatkan kembali bagaimana mencaii, menulis dan menurunkan berita yang berkualitas yang sekiranya bisa disenangi dan dibutuhkan masyarakat. Pengarahan dilakukan Dahlan Iskan setiap pagi di kantor selama beberapa minggu.

Selain itu, (manajemen melakukan degradasi terhadap bagian redaksinya. Reporter yang dianggap kualitasnya rendah, dipindahkan ke bagian lain tapi masih dilingkungan perusahaan PT Jawa Pos dan sebagian lain dipindah-tugaskan ke perusahaan anak-anak perusahaan. Menurut Dahlan Iskan, diantara mereka ada yang ditugaskan untuk ikut membantu di Sl (Suara Indonesia), koran ekbis anak perusahaan dan ada yang diperbantukan ke koran Malang Pos, koran anak perusahaan Jawci Pos yang berbasis di Malang, Jatim.

Karyawan PT Jawa Pos yang dipindah-tugaskan itu tidak seluruhnya karena terkena degradasi. Sebagian diantara mereka sebenamya dinifai berkualitas bagus dan tetap layak di Jawa Pos. Namun sejalan dengan prinsip perampingan (efisiensi tenaga) dan sekaligus mengoptimalkan kineria karyawan di PT Jawa Pos, mereka yang berkualitas itu diminta untuk membenahi anak-anak perusahaan.

Sebagai koran harian yang menjual berita kepada pelanggannya, manajemen PT Jawa Pos sangat memperhatikan soal desain dan variasi produknya. Tujuannya agar pelanggan koran tetap menyukainya dan tidak merasa bosan. Karena itu, desain koran meski halamannya tetap berbentuk segi empat namun tata wajahnya bisa sering berubah. Hampir tiap hari ada perubahan kecil pada tata wajah. Begitu pula variasi beritanya. Adakalanya berita-berita politik yang mendominasi halaman koran, namur adakalanya berita-berita ekonomi atau kriminal atau olahraga yang mendominasinya.

\section{c. Meningkatkan Nilai Voucher}

Sebagai salah satu bentuk pemberian layanan dalam soal produk kepada pelanggan, manajemen PT Jawa Pos selama 2001 berupaya 
meningkatkan kualitas pelayanan kepada mereka (pelanggan). Selain kian memberikan kepastian bahwa jam kedatangan koran di tangan pembaca lebih pagi, juga memberikan voucher kepada pelanggan yang menerima koran terlambat atau tidak menerima koran dari agen atau penyalurya.

Pemberian voucher ini sebenamya sudah dilakukan sejak beberapa tahun lalu narnun selama 2001 nilainya ditingkatkan. Dari semula senilai Rp 1.000 ditingkatkan menjadi Rp 1.500 setiap satu kali tidak menerima koran. Ini artinya, bagi pelanggan koran Jawa Pos yang tidak menerima koran satu kali (satu hari) maka dia berhak mendapatkan voucher itu. Voucher akan diperhitungkan saat pembayaran uang langganan. Dan meski sudah mendapatkan voucher, bagi pelanggan yang tidak menerima koran bisa meminta ke bagian pengaduan pelanggan agar diberi koran pengganti pada hari itu juga. Pemberian koran pengganti ini bisa dilayani sekitar satujam setelah adanya pengaduan.

\section{d. Melakukan Diskrimmasi Harga}

Selama 2001 manajemen Jawa Pos tercatat dua kali menaikkan harga produknya. Mulai 1 Januari 2001 harga dinaikkan dari semula Rp 18.000 per bulan untuk langganan menjadi $R p 20.000$. kenaikan harga ini dimaksudk.an untuk mengurangi kerugian yang terialu besar bagi Jawa Pos akibat tingginya kenaikan harga kertas koran. Pada Juni 2001, perusahaan ini menetapkan harga baru langganannya menjadi R-p 25.000 per wulan.

Tentang ongkos kirim ini, dalam kota rata-rata Rp 10 per eksemplar. Namun untuk luar pulau misalnya Samarinda di Kalimatan Timur, ongkos kirim itu bisa mencapai Rp 400 per eksemplar. Karena itu, harga jual koran disana (harga ke agen), mencapai Rp 1.100 per eksempiar.

Harga jual koran Jawa Pos, seperti disebut diatas, masih lebih tinggi dibanding dengan koran pesaingnya. Harga jual Jawa Pos yang cukup tinggi itu juga karena biaya operasionalnya tinggi, Sementara biaya produksi maupun biaya operasional koran kompetitor tidak setinggi, Jalva Pos. Antara lain, karena kompensasi yang diberikan manajemen kepada karyawannya, secara umum lebih tinggi (lebih baik) dibanding kompensasi yang diberik an perusahaan kompetitor kepada karyawannya.

Karena itu, selatna 2001 manajemen Jawa Pos melakukan berbagai efisiensi. Misalnya memotong gaji direksi antara 15 persen hingga 25 persen, memotong tunjangan profesi redaksi hingga 50 persen, efisiensi 
dalam penggunaan telepon, melikuidasi sejumlah kantor biro (terutama di Jatim) dan mengurangijatah rekening telepon untuk wartawan di daerahdaerah.

Saat gencar-gencamya gerakan reformasi harga kertas koran tinggi, sementara harga jual koran lebih rendah dibanding dengan HPP-nya. Saat itu Jawa Pos mengalami kerugian jika hanya mengandalkan dari penjualan koran. Saat itu perusahaan mi menerapkan kebijaksanaan menekan oplah. Artinya, meskipun pada saat itu permintaan koran cukup tinggi, namun perusahaan kurang tertarik untuk memenuhi permintaan mereka itu. Sebab dalam perhitungan manajemen, menjual koran saat itu rugi.

Untuk menekan oplah itu, manajemen membatasi secara ketat terhadap jatah para agennya. Caranya, agen yang minta tambahan jatah, tidak dilarang, namun dikenai harga khusus yang lebih mahal atas jatah tambahan tersebut.

Tujuan diterapkannya kebijaksanaan pembedaan (diskriminasi) harga itu, antara lain adalah untuk menekan pennintaan agen-agen. Sebab Jawa Pos ingin menekan angka kerugian dari sektor penjualan produknya. Apalagi saat itu perolehan iklanjuga turun.

Namun diakui pihak manajemen bahwa kebijaksanaan diskriminasi harga itu menjadi bumerang. Kebijaksanaan itu malah merugikan perusahaan. Sebab asen-agen banyak yang lari ke perusahaan kompetitor. Artinya, agen yang membutuhkan tambahan koran akhimya minta ke perusahaan kompetitor Jawa ros. Akibatnya, koran kompetitor oplannya saat itu memngKat tajam, sememara oplah Jawa Pos menurun.

PT Jawa Pos lalu bangkit untuk menebus kekeliruannya itu-Caranya, agen-agen multimedia, yaitu agen yang tidak hanya menjual koran Jawa Pos namun juga menjual koran-koran lain, diawasi secara ketat. Agen-agen iTiultimedia yang jatah koran dari kompetitomva tebih dari sepertiga jatah koran dari Jawa Pos, dikenai harga lebih mahal $\mathrm{Rp} 50$ rupiah per eksemplar. Banyak agen yang mengurangi penjualan koran kompetitor Jawa Pos dan lebih memilih memperbanyak penjualan Jalva Pos. Sebab mereka menilai, penjualan koran ini masih lebih prospektif dibanding dengan penjualan koran kompetitor. Disini PT Jawa Pos betul-betul memanfaatkan kekuatannya, terutama yan^ menyangkut brand name dan bromd image !ly3. untuk nielawan kotnpetitornya. Namun setelah Jawa Pos melakukan strategi 
seperti itu, oplah koran kompetitor itu berangsur-angsur menurun hingga kini tinggal sekitar 60 ribu per hari.

\section{e. Memacu Perolehan Iklan}

Manajemen inenyadari bahwa perolehan iklan selama krisis ekonomi 1998 terus menurun. Karena itu, untuk tetap mempertahankan perolehan iklan selama krisis, manajemen melakukan terobosan apa yang disebutnya dengan parinering. Yaitu menggandengkan wartawan dengan bagian lain, terutama bagian iklan untuk bersama-sama mencari iklan.

Tujuan partnering ini, adalah lebih mendinamisasi bagian-bagian lain yang dianggapnya masih perlu ditingkatkan. Manajemen menyadari bahwa dengan berkurangnya jumlah dan lebar halaman koran maka bagaimanapim ruang untuk berita menjadi berkurang. Karena itu, agar wartawan tetap punya beban kerja yang cukup apalagi di saat krisis ekonomi maka ada beberapa wartawan yang diwajibkan ikut program partnering bekerjasama dengan bagian iklan untuk mencari iklan. Sebab pemasukan dari iklan merupakan salah satu sumber utama pendapatan perusahaan pers. Jika pemasukan dari iklan kecil apalagi tidak ada, maka perusahaan pers tidak akan bisa survive. Program partnering ini berlangsung empat bulan, yaitu selama krisis moneter mencapal puncaknya dan kemudian dihentikan setelah kondisi dianggap berdngsur-angsur stabil.

Selain itu, manajemen juga melakukan efisiensi dalam pemakaian space

untuk iklan, khususnya iklanjitu. Sebab menurut perhitungan pihak manajemen, saat harga kertas koran mahal (tinggi), perolehan dari iklanjitu masih lebih rendah dibanding dengan pemakaian kertasnya. Karena itu, manajemen lalu membikin terobosan. Jenis dan ukuran huruf untuk teks iklan Jitu diperkecil sementara nomor kode iklan yang biasanya dicantumkan di bagian bawah teks iklan Jitu dihilangkan karena dianggap pemborosan tempat. Selain itu, bagian tengah halaman yang sebelumnya ada mang kosong, digunakan urituk satu kolom iklan jitu. Akibatnya iklan jitu mer.jadi lebih padat. Dengan kata lain, daya tampung halaman iklanjitu terhadap iklan menjadi lebih banyak, sebabjumlah kolom pada halaman berita. Artinyajika pada halaman berita setiap dua halaman hanya te diri atas 14 kolom setiap halaman tujuh kolom namun khusus untuk dua halaman iklan jitu terdiri atas 15 kolom karena setiap halamannya bisa menampung 7,5 kolom. 


\section{f. Memperbesar Diskon dan Periode Pembayaran}

Strategi lain dalam soal harga manajemen PT Jawa Pos selama 2001 memberikan diskon yang lebih besar kepada agen-agennya yang bisa membayar koran secara kontan. Tahun-tahun sebelumnya diskon seperti itu sebenarnya sudah diberikan namun selama 2001 makin ditingkatkan. Dari yang semula hanya3 persen, lalu ditingkatkan menjadi 5 persen bagi agen yang mau membayar^ korannya secara kontan.

Pemberian diskon ini, dimaksudkan untuk merangsang agen-agen untuk mau segera membayar koran yang dibelinya. Juga sekaligus untuk mengimbangi bunga deposito di bank yang selama 2001 cukup tinggi. Pertimbangannya, jika tidak ada diskon untuk agen yang membayar kontan atau ada diskon namun rendah dikhawatirkan agen-agen akan lebih suka menahan uangnya untuk didepositokan terlebih dulu di bank dengan harapan mereka bisa mendapatkan bunga dari deposito yang saat itu cukup tinggi. Karena itu, dengan adanya rangsangan diskon 5 persen itu agenagen Jawa Pos diharapkan lebih sukamembayarkan uangnya secara kontan daripada didepositokan dulu di bank selama satu atau dua bulan.

Dalam kaitannya dengan masa pembayaran (Payment period and credit term ), manajenmen PT. Jawa Pos juga melakukan perubaha. Sebelum krisis ekonomi 2001, masa piutang iklan perusahaan bisa sampai 90 hari namun akhirnya diperpendek menjadi tinggal 60 hari. Sedangkan piutang koran diagen-agen yang semula 45 hari diperpendek menjadi tinggal 25 hari. Artinya, sebelum 2001 pemasang iklan ataupun biro iklan diperbolehkan membayar biaya pemasangan iklannya 90 hari setelah iklannya termuat dikoran. Begitu pula agen berhak membayar koran yang dibelinya selama 45 hari setelah pembelian.

Keberhasilan memperpendek piutang perusahaan itu, berkat kerja sama yang baik antara beberapa bagian melalui program partnering. Program ini dilakukan selama empat bulan dalam tahun 2001. Wujudnya bagian wartawan digandengkan dengan bagian iklan dan bagian keuangan untuk mencari iklan, termasuk melakukan penagihan piutang perusahaan. Dalam hal ini manajemen Jawa Pos memanfaatkan keunggulannya di bidang SDM (Sumber Daya Manusia) yang cukup banyak. Apalagi, ketika koran terbit 16 halarian dengan ukuran tujun kolom, maka ada sejur.lah tenaga di bagian wartawan (redaksi) yang beban kerjanya berkurang. Karena, itu dengan pertimbangan bahwa disaat krisis tenaga kerja harus 
lebih dioptimalkan, maka sejumlah wartawan ditugaskan juga mencari iklan bersama bagian iklan. Sebagian lainnya ditugaskan juga mencari iklan bersama bagian iklan. Sebagian lainnya ditugaskan meiakukan penagihan piutang perusahaan bersama bagian keuangan.

\section{g. Memperkuat Distribusi Lewat SCJJ}

Di bidang layanan distribusi, manajemen PT. Jawa Pos melakukan berbagai perubahan. Tujuan utamanya adalah untuk meningkatkan kepuasan pelanggan, khususnya dalam hal kedatangan koran di tangan pembaca.

Langkah itu diwujudkan dengan satu tekad untuk lebih menyegerakanjam kedatangan koran di tangan pembaca. Caranya dengan melakukan sistem cetak jarak jauh (SCJJ) di Solo dan Jakarta. Dengan menggunakan SCJJ ini maka pembaca di Solo dan sekitarnya maupun yang di DKI Jakarta dan sekitarnya bisa menerima koran dalam waktu yang hampir sama dengan pembaca di Surabaya dan sekitarnya.

Sebelum menggunakan SCJL pembaca di Solo dan sekitarnya menerima kiriman koran dari Surabaya. Begitu pula pembaca'yang di DKI Jakarta dan sekitarnya. Akibatnya, karena pengiriman ke Solo melaluijalan darat (bukan pesawat) satu angkutan dengan koran untuk wilayah Madiun dan sekitarnya, maka jam kedatangan koran di Solo dan sekitarnya sering siang (terlambat). Namun, dengan diterapkannya SCJj di Solo, mai,a sebagian koran bisa dicetak di sana, lalu diedarkan untuk pembacanya di kota itu dan sekitarnya:

Dari total oplah Jawa Pos yang kini sekitar 310 ribu eksemplar sehari, 50 ribu eksemplar diantaranya dicetak di Solo. Sedangkan yang di Jakarta dicetak 25.000 eksemplar.

Koran yang dicetak di Solo untuk melayani pembaca di Solo, Kudus, Jepara, Cilacap, Yogyakarta, Semarang dan beberapa kota lainnya di Jateng. Sedangkan yang dicetak di Jakarta untuk melayani pembacanya di ibu kota negara itu dan Bali.

Sebelum ada SCJJ di Jakarta, pembaca di Bali dikirimi koran dari Surabaya satu mobil dengan koran untuk wilayah Banyuwangi dan sekitamya- Atau terkadang lewat pesawat dari Surabaya. Akibatnya, jam kedatangan koran Jctlva Pos di Bali siang sekitar pukul 11.00. Dengan 
dilayani dari Jakarta lewat pesawat udara,jam kedatangan koraii di Bali bisa lebih pagi. Selain itu, pengirimannya juga lebih tegamin kepastiannya.

Karena ada SCJJ di Solo dan Jakarta, maka manajemen menambahjumlah angkutan, baik yang untuk melayani Solo dan sekitamya, maupun yang untuk melayani Jakarta dan sekitamya serta Bali. Dengan cara seperti itu maka secara umum jam kedatangan koran Jawa Pos ditangan pembaca menjadi lebih awal (Pagi).

Bagi surat kabar, jam kedatangan ini sangat menentukan laku atau tidaknya produk itu. Apalagi untuk koran pagi. Koran yang bisa datang atau menemui pembacanya lebih awal dibanding pesaingnya, maka peluang untuk laku menjadi lebih besar. Sebaliknya, koran yang datangnya terlambat, atau lebih belakangan dibanding pesaingnya, maka peluang untuk tidak terjual menjadi lebih besar. Dengan demikian, jika misalnya ada dua koran atau lebih yang kualitasnya kurang lebth sama, maka pembaca akan lebih memilih koran yang bisa datang lebih awal.

h. MemperbanyakJaringan Distribusi

Selain dengan menerapkan SCJJ di Solo dan Jakarta, manajemen Jawa Pos selama 2001 juga memperbanyak agen atau penyalumya. Ini dimaksudkan agar masyarakat yang hendak membeli Jawa Pos bisa kian lebih mudah mendapatkannya. Khusus untuk Surabaya, misalnya, agennya yang semula 120 buah ditingkatkan menjadi 130 buah untuk pelanggan. Sedangkan agen yang khusus melayani eceran dari semula 55 orang ditingkatkan menjadi 60 orang. Sementara agen di Jatim (di luar Surabaya) dari semula 475 agen menjadi 500 agen. Sedangkan agen di Jateng dari 140 menjadi 170. Jumlah agen di Jateng ini mengalami banyak penambahiın karena Jawa Pos sedang ekspansi pasar di sana.

Pada tahun 2001, bagian pemasaran PT. Jawa Pos bermaksud memperkuat sistem distribusinya. Sebab diakui oleh manajemen perusahaan ini bahwa tampilan korannya yang kini hanya tujuh kolom, sehingga lebih sempit dua kolom dibanding koran kompetitomya, itu merupakan salah satu titik kelemahan koran ini. Sebab, dengan tampil lebih sempit; inaka ada anggapan bahwa koran ini koran mini. Selain itu, karena koran makin sempit maka ruang untuk berita menjadi berkurang. F adahal, umumnya pembaca yang membeH surat kabar, salah satu tujuannya adalah untuk bisa mendapatkan berita yang sebanyak-banyaknya dan sebaik-baiknya. Dengan 
koran kian sempit maka kapasitas atau daya tampung koran terhadap beritajuga berkurang. Apalagijika ruangnya banyak dihabiskan untuk iklan.

Melalui penambahan jaringan distribusi itu tampak sekali manajemen Jawa Pos ingin memanfaatkan sebaik-baiknya tentang keunggulannya/kekuatannya untuk menghadapi krisis ekonomi 2001. Keunggulannya berupa kecukupan modal, tenaga kerja dan peiıalaman dan kemampuan dalam penguasaan teknologi pencetakan koran, diniantaatkan untuk melakukan SCJJ demi lebih mempercepat kedatangan koran di tangan pembaca. Begitu pula penguasaan jaringan distnbusi dan kepemilikan power berupa brand name dan brand image, dimaniaatkan untuk lebih memperbanyak agen agar pelayanan kepada pelanggan bisa kian cepat dan mudah.

i. Promosi, Membangun Image Koran Modern

Pada saat harga kertas koran mahal dan fluktuatif, sementara perusahaan pers belum berani menyesuaikan harga jual produknya, perusahaan penerbitan pers hidup dalam kondisi yang dilematis. Satu sisi mereka tidak ingin oplahnya menurun karena berarti market share-nya menjadi rendah yaing dikhawatirkan akan berpengaruh pada minat pemasang iklan. Namun pada sisi yang lain perusahaan tidak ingin, atau tidak berani menaikkan oplah karena khawatir kerugian akibat penjualan koran kian besar.

PT. Jawa Pos juga mengalami kondisi seperti itu. Saat harga kertas koran mahal, perusahaan ini mengalami rugi besar akibat pemasukan dari hasil penjualan koran tidak sesuai dengan biaya produksi yang harus dikeluarkan. Namun untuk menaikkan harga jual koran juga tidak punya keberanian sebab kondisi ekstemal yang tidak memungkinkan. Misalnya karena menyadari daya beli masyarakat sedang menurun, dan kompetitor juga tidak atau belum menaikkan harga.

Manajemen PT. Jawa Pos waktu itu sempat memilih membatasi atau bahkan mengurangi oplah, Sebelum itu, oplah koran ini sekitar 310 ribu eksemplar- Saat krisis kertas, manajemen sempat menginginkan hanya mencetak 200 ribu eksemplar. Yang berarti ada sekitar seratus ribu pelanggannya yang bakal tidak terlayani. ini tujuannya untuk menghemat kertas, dan sekaligus mengurangi/memperkecil kerugian. 
Cara yang dilakukan manajemen perusahaan ini adalah dengan membatasi jatah agen melalui diskriminasi harga. Namun temyata kebijaksanaan itu justru merugikan perusahaan, kemudian hal itu dicabut atau dihentikan.

Karena itu, manajernen Jawa Pos tetap berusaha mempertahankan image - nya di mata masyarakat. Caranya dengan melakukan promosi (advertising) melalui radio swasta dan media massa cetak lainnya seperti majalah berita mingguan Tempo Jakarta.

Iklan itu terutama untuk membangun image masyarakat terhadap koran. Jawa Pos berkaitan dengan mulai ditampilkannya koran wajah baru yang hanya tujuh kolom dengan sebutan Broadsheet Jimior. Manajemen perlu keija keras agar produk barunya yang masih sangat asing di mata sebagian besar masyarakat pembaca koran di Indonesia, bisa diterima mereka. Bersamaan dengan diluncurkannya produk baru itu, yaitu Februari 2001, inanajemen melakukan riset pasar, minta tanggapan dan penilaian masyarakat tentang produk baru itu. Hasilnya sebagian besar menyatakan bisa menerimanya dengan alasan lebih praktis, lebih handy, dan lebih modern.

Demi membangun image bahwa koran wajah baru itu modern, manajemen memasang koran-koran ternama Amerika Serikat sebagai contoh atau sebagai model iklan. Dengan memasang koran-koran ternama Amerika Serikat yang berukuran tujuh kolom (broadsheet junior, wajah baru jawa Pos), bertahap pembaca punya image bahwa koran modern memang berukuran seperti itu (tujuh kolom), dan bukan lagi sembilan kolom. Akan berbeda seandainya yang dijadikan iklan koran tujuh kolom itu terbitan negara berkembang, maka image masyarakat akan berbeda. Ini namanya membangun image masyarakat terhadap prodık.

Surabaya, 27 Desember 2001

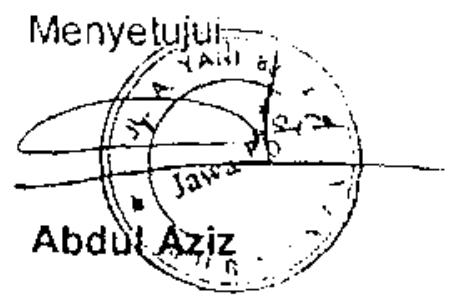


Realisasi Penjualan per Daerah

\begin{tabular}{|c|c|c|c|c|c|c|c|c|c|}
\hline \multirow{2}{*}{$\begin{array}{c}\text { Doerah: } \\
\text { Pemasaran }\end{array}$} & \multicolumn{9}{|c|}{ Tohun } \\
\hline & 1994 & 1995 & 1996 & 1997 & 1998 & 1999 & 2000 & 2001 & 2002 \\
\hline \multicolumn{10}{|l|}{ Surabaya } \\
\hline A. Langganen & 73,000 & 80.400 & 74.800 & 92.000 & 92,000 & 101,200 & 106.260 & 111,573 & 101,275 \\
\hline B. Eceran & 39,000 & 42,300 & 42,800 & 37,250 & 36.200 & 42,000 & 44,100 & 44,225 & 48,900 \\
\hline $\begin{array}{l}\text { Jawa Timur } \\
\text { (Non Surabaya) }\end{array}$ & 138,000 & 137,600 & 148,600 & 135,000 & 132,200 & 128,500 & 133,650 & 136,000 & 145,125 \\
\hline Jateng \& OIY & 17,500 & 24,600 & 27,400 &, + \pm 200 & 41.600 & 42,000 & 42,300 & 42,800 & 44,050 \\
\hline DKI \& Jabar & 3.000 & 13,800 & 6,000 & 3.500 & 3.400 & 1,500 & 1,575 & 3.575 & 6.650 \\
\hline Bali & 12,750 & 23,300 & 15,000 & 7,000 & 16,500 & 9.700 & 10.185 & 13,500 & 14,600 \\
\hline Luar Pulau & 23,500 & 22,600 & 33,800 & 23,500 & 13,800 & 8,800 & 10.100 & 18.500 & 19.750 \\
\hline Joya Pos & - & $\dot{-}$ & - & - & - & 4.200 & 4,410 & 4,500 & 7,200 \\
\hline Total & 306,750 & 344,600 & 348,400 & 339.450 & 335.700 & 337,900 & 352,580 & 374.773 & 387,550 \\
\hline Jumlah Agen & 1,207 & 1,248 & 1,301 & 1,357 & 1,381 & 1,393 & 1409 & 1409 & 1409 \\
\hline
\end{tabular}

Sumber: PT. Jowa Pos

catatan: th 1997, 1998, 1999 terjadi krisis monoter jatah dikurangi (eceran) 


\section{ASSEIS}

\section{CURRENT ASSETS}

Cash and cash equivalents

Trade accounts receivable - third parties - net of allowance for doublful accounts of $\mathrm{Rp} 431,753,536$ in 2001 and Rp $312,642,054$ in 2000

Advances

Prepaid expenses

Tolal Curren! Assels

\section{NONCURRENT ASSETS}

Accounls receivable from related parties inveslments in shares of slocks in subsidiaries Advances for iong-term investments

Property. plant and equipment - nel of accumulated depreciation of $R p 56,653,733,348$ in 2001 and $R p 64,339,826,063$ in 2000

Total Noncurrent Assels

TOTAL ASSETS

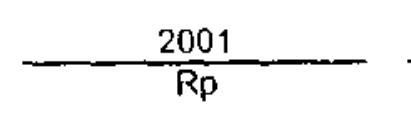

(As restalcd - Note 2)

\begin{tabular}{|c|c|}
\hline $4,925,956,432$ & 11.164 .510 .978 \\
\hline $\begin{array}{r}19,817,304,512 \\
847,487,300 \\
57,477,926 \\
\end{array}$ & $\begin{array}{r}20,980,117,587 \\
301,264,285 \\
49,617,120 \\
\end{array}$ \\
\hline $25,648,226,170$ & $32,495,509,970$ \\
\hline $\begin{array}{r}19,087,205,178 \\
132,720,383,300 \\
17,968,000,000\end{array}$ & $\begin{array}{l}30,226,458,765 \\
58,352,670,818 \\
15,293,000,000\end{array}$ \\
\hline $31,466,343,894$ & $27.629,718,999$ \\
\hline $201,241,932,372$ & $131,501,848,582$ \\
\hline $226,800,158,542$ & $163,997,358,552$ \\
\hline
\end{tabular}

See accompanying notes to financial stalements which are an integral part of the financial statements. 


\begin{tabular}{|c|c|c|}
\hline & $\underbrace{2001}_{\mathrm{Rp}}$ & $\frac{\left(\begin{array}{c}2000 \\
\text { (As restaled - Note 2) }\end{array}\right.}{\text { Rp }}$ \\
\hline \multicolumn{3}{|l|}{ LABILUTES AND EQUITY } \\
\hline \multicolumn{3}{|l|}{ CURRENT LIABILITIES } \\
\hline Bank loans & $43,781,871,241$ & $24,708,057,748$ \\
\hline Unearned revenue & $75,898,186$ & $234,104,471$ \\
\hline Taxes payable & $5,163,986,833$ & $8,931.381,161$ \\
\hline Accrued expenses & $1,577,848,067$ & $1,006,829,227$ \\
\hline Other accounts payable - third parties & $504,066,381$ & $1,884,365,059$ \\
\hline \multicolumn{3}{|l|}{ Current maturities of long-term liabilities } \\
\hline Bank loans & $10,484,000,000$ & $4,583,199182$ \\
\hline Lease liabilities & - & $3.911,043,185$ \\
\hline Liability for purchase of machinery & $1,859,640,818$ & $4,328,836,682$ \\
\hline Total Current Liabilities & $63,447,311,526$ & $49,587,816,715$ \\
\hline \multicolumn{3}{|l|}{ NONCURRENT LIABILITIES } \\
\hline Deferred lax liabilities - net & $1,863,496,790$ & $\{, 905,525,372$ \\
\hline Accounts payable to related parties & $136,512,155$ & $3,058,962,552$ \\
\hline \multicolumn{3}{|l|}{ Long-term liabilities - net ol current maturities } \\
\hline Bank loans & $22,366,000,000$ & $1,333,311,979$ \\
\hline Liabilily for purchase of machinery & $\cdot$ & $1,803,683,273$ \\
\hline Decierred gain on sale and leascback transaction - nct & $=$ & $50,802,822$ \\
\hline Tolal Noncurrent Liabiities & $24,366,008,945$ & $8,152,285,998$ \\
\hline \\
\hline $\begin{array}{l}\text { Capilal slock - Rp } 1,000 \text { par value per share } \\
\text { Authorized }-20,000,000 \text { shares }\end{array}$ & & \\
\hline Subscribed and paid-up - 20.000 .000 shares & $20,000,000,000$ & $20,000,000,000$ \\
\hline Relained earnings & $119,076,838.071$ & $86,257,255,839$ \\
\hline Tolal Equily & $139,076,838,071$ & $106.257,255,839$ \\
\hline TOTAL LIABILITIES AND EQUITY & $226,890,158,542$ & $=163,997,358,552$ \\
\hline
\end{tabular}

See accompanying notes to financial statements

which are an integral part of the financiai statements. 
PT JAWA POS CONCERN LTD.

STATEMENTS OF INCOME

NET SALES / REVENUES

COST OF GOODS SOLD

GROSS PROFIT

OPERATING EXPENSES

Selling

General and adminstrative

Total Operating Expenses

INCOME FROM OPERATIONS

OTHEF INCOML (CIHARGES)

Loss on forcign exchange - het

Interest expense and bank charges

income from building rental

interest income

Equity in ret income of subsiciaries

Gain on sale of property, planl and eciuipment

Bad deists expense

Others - net

Olher Charges - Net

INCOME BEFORE TAX

TAX EXPENSE

INCOME AFTERTAX

LOSS ON DISPOSAL OF SUBSIDIARY

INCOME BEFCRE LOSS ON DISPOSAL OF

DISCONTINUED OPERATION

LOSS ON DISPOSAL OF DISCONTUUNED OPERATION

NET INCOME
2000

(As restated - Note 2)

$188,029,220,120$

$240,777,087,934$

$103,673,095,074$

$77,103,992,860$

$62,656.102,226$

$\begin{array}{r}21,402,835,520 \\ 14,436,321,241 \\ -\quad 35,839,156,761 \\ \hline 41,264,836,099 \\ \hline\end{array}$

$13,798,738,930$

$10,723,754,032$

24.522 .492 .962

$38,133,609,264$

$(542,107,331)$

$(10,653,573,991)$

$705,000,000$

$464,572,540$

$12,485,598,023$

$1,257,313,978$

(119,111,462)

(273. 63.445)

$3,324,228,312$

$44,589,064,411$

$(9.181 .424,695)$

$35,407,639,710$

$(4,938,381,797)$

$(3,968,672,376)$

$705,000,000$

$274,310,728$

$11,816,210,419$

-

(167,392,878)

$162,993,200$

$3,884,067,296$

$42,017,676,560$

$(9,773,819,243)$

$32,243,857,317$

$(2,588,057,484)$

$32,819,582,232$

$32,243,857,317$

$(800,000,000)$

$31,443,857,317$

See accompanying notes to financial statements

which are an iniegral part of the finencial statements. 
PT JAWA POS CONCERMLTD.

STATEMENTS OF CHANGES IN EQUITY

FOR THE YEARS ENDED DECEMBER 31,2001 ANE 2000

Balance as of Jamuary 1,2000

Change in accounting policy dic to adoption of PSAK No. 46

Balance as reslated

Net income lor the year

Balance as of December 31, 2000

Not income for the year

Balance as of December 31. 2001

\begin{tabular}{|c|c|c|}
\hline $\begin{array}{l}\text { Paid-up } \\
\text { capilal slock }\end{array}$ & Relained carnings & Total equity \\
\hline$R_{p}$ & $R_{p}$ & $\overrightarrow{R p}$ \\
\hline $20,000.000,000$ & $55,041,899,148$ & $75,941,890,148$ \\
\hline- & $(1,128,500,626\rangle$ & $(1,128,500,626)$ \\
\hline $20,000,000,000$ & $54,813,398,522$ & $74,813,398,522$ \\
\hline- & $31.443,357.317$ & $31,443,857,317$ \\
\hline $20,000,000,000$ & $86,257,255,839$ & $106,257,255,839$ \\
\hline$=$ & $32.810 .582,232$ & $32,819.582,232$ \\
\hline $20,000,000,000$ & $119,076,838,071$ & $139,076,838,071$ \\
\hline
\end{tabular}

See accompanying notes to financial slatements

which are an integral part of the financial statements. 


\section{$A K I \perp V A$}

AKTIVA LANCAR

Kas dan selaral ka:

11.164 .510 .978

2.800 .327 .636

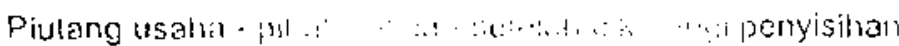

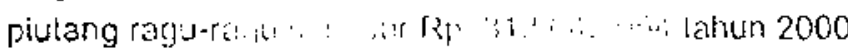
dan Rp 105.9?: : : : : $1: 1, \cdots$

Piviang lain-lain - $1:$ : : i i;

Uang muka prembi-li...

Biaya dibayat ,

Jumlah Aktwas i ist.

AKTIVA TIOAK! L !'

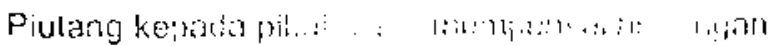
istimew:

10.544 .5 .59 .542

12.313 .262 .808

$\$ 3.853 .362 .497$

47.336 .460 .399

Invesiasi sitilis

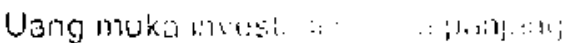

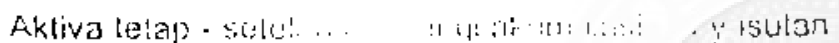

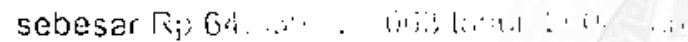

$\operatorname{Rp} 56.49 \% 22 \%$, i ' $3:$

Jumlah Aktiva Tid:

JUM!AH AKI UA

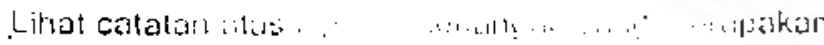

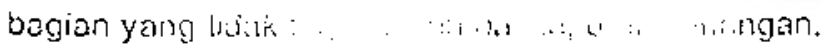

15.293 .040 .000

15.293 .000 .000

\begin{tabular}{|c|c|}
\hline 27.029 .713 .999 & 31.094 .562 .527 \\
\hline $\mathrm{i}: 0.325 .211 .033$ & 106.037 .285 .734 \\
\hline is.4.498.5.0.231 & 126.181 .677 .606 \\
\hline
\end{tabular}

16.856 .091 .556

65.032 .960

378.164 .500

50.775.220

20.144 .391 .872 


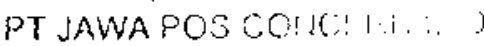

NERACA

31 DESEMBER ?OI:

$$
-\cdots \cdot \frac{2000}{R p}
$$

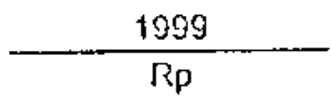

KEWAJIBAM DAN 'D!

KEWAJIBAN I.ANC: $Y:$

Hulang bank

$\because 708.057 .748$

$234.10+1.471$

1). $931.38: 161$

Hulang pajak

1.000 .820 .227

Blaya masih: hal us . it?:.....

Hutang lain-laı

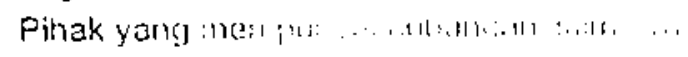

1.415 .5611 .026

$1.884 .365,059$

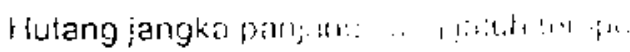

dalam waklu :ain 1 i:

Bank

Sewa guna lisit .:

Pembelien !nus!: ,

junlab Kewaljibian! . .

1.643 .3513 .726

1.643 .393 .726

Hulang kepart:a ;ili

huisurgan astris :

Hutang jangki] pu:

bagian yang :ath

satu tahum

Bank

1.333 .311 .979

$3.9 \$ 1.043 .185$

.323 .836 .682

$1,003.385 .541$

17.050 .112 .658

256.209.901

1.741 .827 .684

138.710 .400

2.023 .804 .896

8.077 .984

Sewa gunál usa! . I

Pembelian mes: :

1.803 .603 .273

4.872 .930 .795

2.890.323.522

4.922 .627 .874

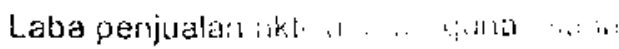

dilanggurkinil - : :

Jumiah Kewaj!ina : :

50.80 .322

$\therefore .831 .1911 .800$

67.737 .094

14.397 .013 .011

\section{EKUITAS}

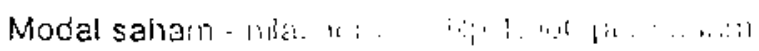

Modai dasar - 2. : : . . thli :

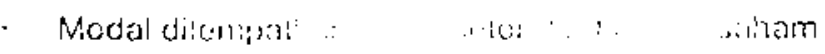

Saldo laba

Jumiah Ekuitis

JUMLAH KEWAIIL: : . . . .

\begin{tabular}{|c|c|}
\hline $0.000 .04 \div .000$ & 20.000 .000 .000 \\
\hline is tib4 us : 890 & 55.941 .899 .148 \\
\hline $1: 14.004 .00 \% .090$ & 75.941 .899 .148 \\
\hline $.4 .4083 .5(n) .23 \cdot 1$ & 126.181 .677 .606 \\
\hline
\end{tabular}

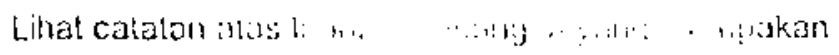

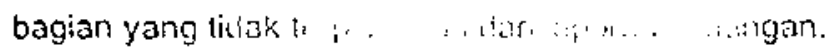


PENJUALAN BER::H!

BEBAN POKOK PIN: ....

LABAKOTOI:

BEEAN USAHA

Penjualar:

Unum dan atamen

Jumlin Belsum las.

LABA USANA

PENGHASILAIU

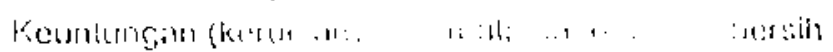

Beban bungis di:n 1 . .

Bagian laba versilin $x$

Pendapalan scis: , :-!

Penghasilan bum]:

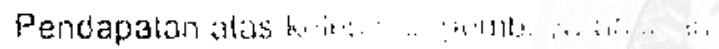

Lain-lain - bersis

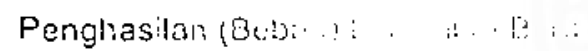

LABA SEBELUI: $\therefore$ i i ili

PAJAK PENGII: $\because$ A

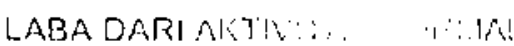

CPERASI YALC: , . . Il :

Rugi pembuburis! $\quad \therefore \quad \quad \therefore$ 小:

LABA BERSII-1

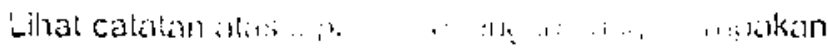

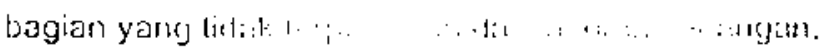

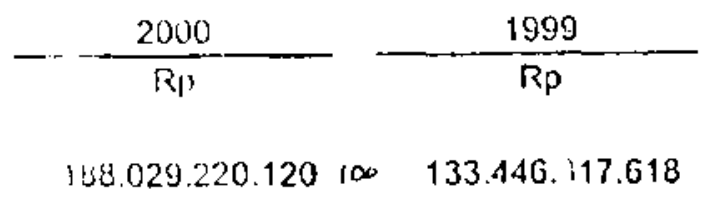

\begin{tabular}{|c|c|c|}
\hline 25.373 .117 .894 & & 85 \\
\hline 26 & & 48.145 .658 .91 \\
\hline
\end{tabular}

\begin{tabular}{|c|c|}
\hline 11.93 .734 .930 & 11.959 .306 .059 \\
\hline i1). .23 .754 .032 & 8.334 .156 .527 \\
\hline$\therefore 522.402 .9621304$ & 20.293 .462 .586 \\
\hline 1 3.1 & 27.852 .106 .327 \\
\hline
\end{tabular}

\begin{tabular}{|c|c|}
\hline (4.933.1241.797) & 7.058 .608 .247 \\
\hline (3.)G(1.6/2.376) & $(8.095 .076 .323)$ \\
\hline .317.412.098 & $4.061 .550 .471^{\circ}$ \\
\hline 705.000 .000 & 750.000 .000 \\
\hline 274.310 .728 & 307.036 .665 \\
\hline 139.330 .820 & - \\
\hline
\end{tabular}

$-\quad \frac{23.150300}{1.52 .151 .853242}-\frac{(444.201 .036)}{3.118 .527 .024}$

1.1880.24:117 22.70 30.970 .723 .351

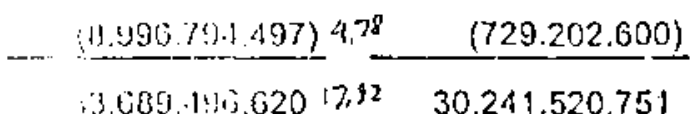

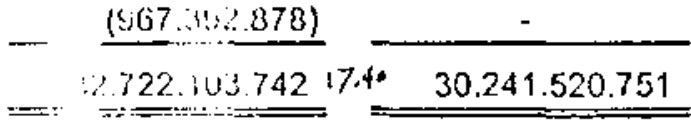




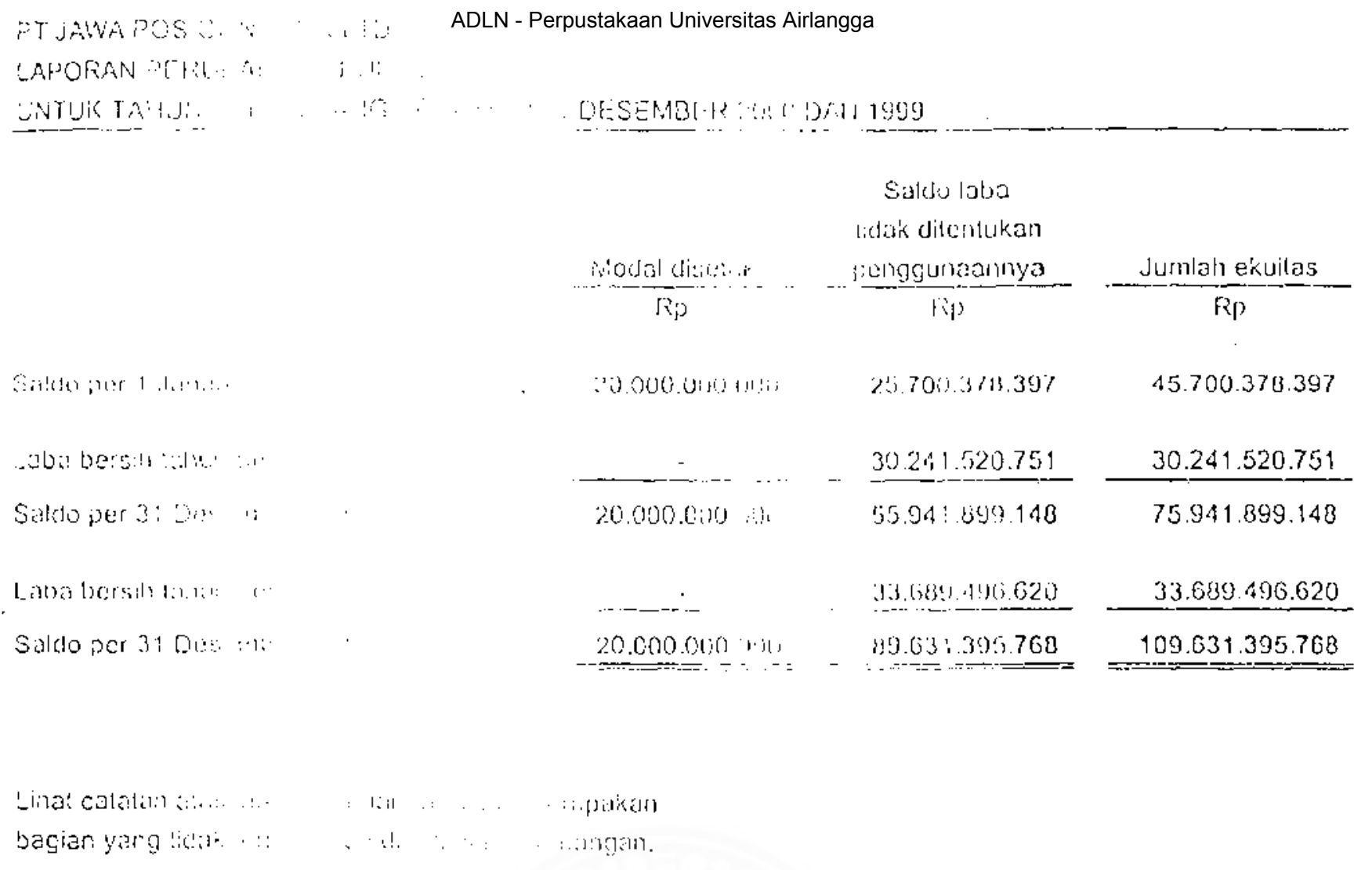

